\title{
Uranium Deposits in the Dripping Spring Quartzite Gila County, Arizona
}

GEOLOGICAL SURVEY BULLETIN 1046-P

This report concerns work done on behalf of the U. S. Atomic Energy Commission and is published with the permission of the Commission

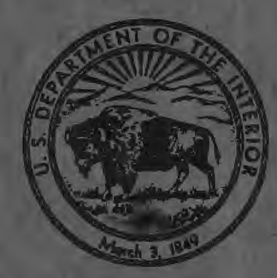




\section{Uranium Deposits in the}

Dripping Spring Quartzite Gila County, Arizona

By HARRY C. GRANGER and ROBERT B. RAUP CONTRIBUTIONS TO THE GEOLOGY OF URANIUM

GEOLOGICALSURVEY BULLETIN 1046-P

This report concerns work done on behalf of the U.S. Atomic Energy Commission and is published with the permission of the Commission

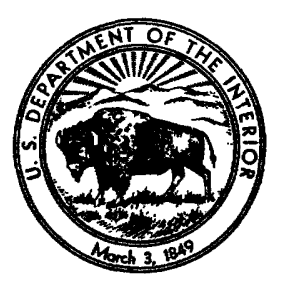




\title{
UNITED STATES DEPARTMENT OF THE INTERIOR
}

\author{
FRED A. SEATON, Secretary
}

\section{GEOLOGIGAL SURVEY}

Thomas B. Nolan, Director

The U. S. Geological Survey Llbrary has cataloged this publication as follows:

\section{Granger, Harry Clifford, 1925-}

Uranium deposits in the Dripping Spring quartzite, Gila County, Arizona, by Harry C. Granger and Robert B. Raup. Washington, U. S. Govt. Print. Off., 1959.

v, $415-486$ p. illus., maps ( 2 fold., 1 col., in pocket) diagrs., tables. $25 \mathrm{~cm}$. (U. S. Geological Survey. Bulletin 1046-P. Contributions to the geology of uranium)

"Literature cited" : p. 482-483.

1. Uranium ores-Arizona-Gila Co. 2. Geology, StratigraphicPrecambrian. 3. Geology-Arizona-Gila Co. I. Raup, Robert Bruce, 1929- joint author. II, 'Title: Dripping Spring quartzite, Gila County, Arizona. (Series: U. S. Geological Survey. Bulletin 1046-P. Series: U. S. Geological Survey. Contributions to the geology of uranium) 


\section{CONTENTS}

\begin{tabular}{|c|c|}
\hline \multirow{3}{*}{ 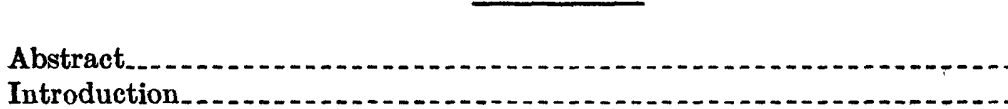 } & Page \\
\hline & $\mathbf{4 1 5}$ \\
\hline & 416 \\
\hline - & 418 \\
\hline ock descriptions. & 419 \\
\hline Sedimentary rocks of the Apache group & 420 \\
\hline Scanlan conglomerate & 420 \\
\hline Pioneer formation & 420 \\
\hline Barnes conglomerate & 421 \\
\hline Dripping Spring quartzite & 422 \\
\hline 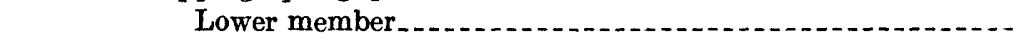 & 423 \\
\hline ber & 424 \\
\hline Mescal limestone. & 426 \\
\hline Igneous rocks, & 426 \\
\hline 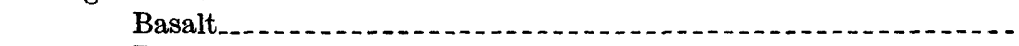 & 426 . \\
\hline nd related rockss..... & 427 \\
\hline toid facies & 428 \\
\hline . & 429 \\
\hline . n- & 429 \\
\hline lated rocks._. & 429 \\
\hline Destos & 434 . \\
\hline boles_-1 & 435 \\
\hline (1) & 435 \\
\hline 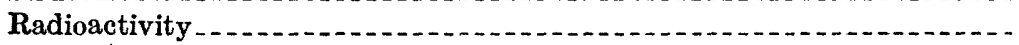 & 438 \\
\hline ranium deposits. & 439 \\
\hline a & 440 \\
\hline$n u^{\prime}$ & 441 \\
\hline shon & 444 \\
\hline ntrols... & 450 \\
\hline - & 453 \\
\hline 的 & 454 \\
\hline 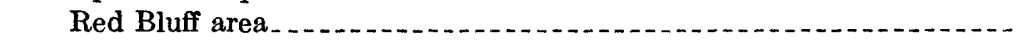 & 454 \\
\hline posit. & 455 \\
\hline posit_... & 457 \\
\hline 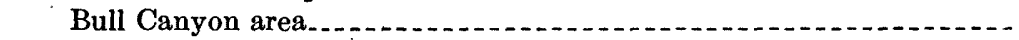 & 459 \\
\hline 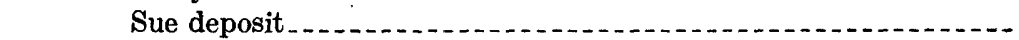 & 459 \\
\hline posit. & 461 \\
\hline rea...... & 463 \\
\hline (1) & 464 \\
\hline (2n-1 & 466 \\
\hline Lost Dog deposit. & 467 \\
\hline Lucky Stop deposit. ...... & 468 \\
\hline posit_.... & 469 \\
\hline Workman deposit ............... & 470 \\
\hline
\end{tabular}




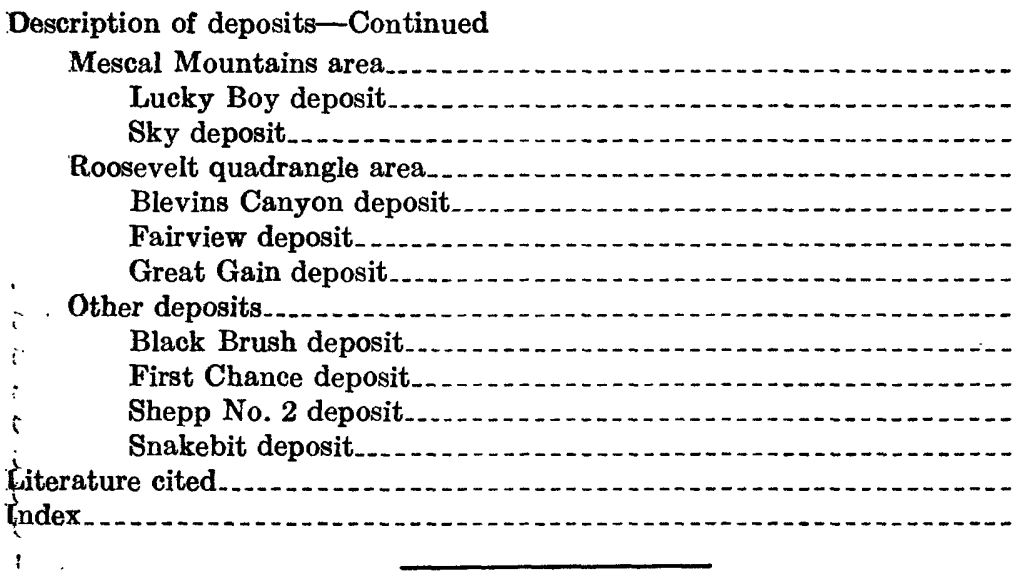

\section{ILLUSTRATIONS}

[Plates in pocket]

Prate 45. Geologic map and section of the Red Bluff area.

46. Map and sections showing geology and mine workings, Red Bluff mine area.

47. Geologic map and sections of the Workman Creek area.

48. Geologic map and section of the Lucky Boy deposit, showing isorads.

Gigure 51. Index map of Gila County, Ariz

52. Generalized columnar section of the Apache group, Gila County, Ariz

53. Generalized columnar section of the Dripping Spring quartzite, Sierra Ancha region, Ariz

54. Scatter diagrams showing correlation between uranium and 10 metals in siltstone and hornfels host rocks.

55. Idealized cross section through pseudochannels

56. Camera-lucida drawing showing the relation of sulfide minerals to uraninite.

57. Camera-lucida drawing of uraninite-bearing veinlet.........

58. Camera-lucida drawing showing pyrrhotite replaced by ohalcopyrite adjacent to molybdenite

59. Map and sections of the Rainbow adit .

60. Maps of mine workings A, B, and C, Red Bluff mine.......-

61. Composite map of the Sue mine.

62. Map of the southern adit on the Donna Lee olaims ......

63. Map and sections of the Hope adit 1.

64. Map of the Little Joe adit 1

65. Map of the Lucky Stop adit 1.......

66. Map and sections of the Workman adit 1

67. Map and sections of the Black Brush adit

68. Geologic map and section of the First Chance deposit........

69. Map of the Shepp No. 2 mine. 


\section{TABIAS}

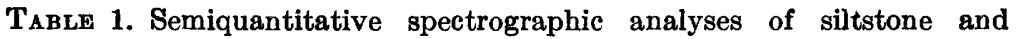
hornfels.

2. Radioactivity measurements of rocks in the Sierra Ancha

3. Radioactivity of gray siltstone of the upper member of the Dripping Spring quartzite 4. Uranium content, in parts per million, of selected diabase
samples. 



\title{
CONTRIBUTIONS TO THE GEOLOGY OF URANIUM
}

\section{URANIUM DEPOSITS IN THE DRIPPING SPRING QUARTZITE, GILA COUNTY, ARIZONA}

\author{
By Harry C. Granger and Robert B. Raup
}

\begin{abstract}
The Dripping Spring is a formation in the Precambrian Apache group that crops out extensively in southeastern Arizona. Nearly all the uranium deposits in the Dripping Spring are in Gila County. This paper is primarily a progress report on studies designed to accumulate geologic data that will aid in the understanding of the localization and the genesis of uranium deposits in the Dripping Spring quartzite.

The Apache group consists of the Scanlan conglomerate, Pioneer formation, Barnes conglomerate, Dripping Spring quartzite, and Mescal limestone. It is underlain by older Precambrian basement rocks, overlain by basalt and a succession of Paleozoic and younger sedimentary rocks, and extensively intruded by diabase.
\end{abstract}

The Dripping Spring and Mescal are locally metamorphosed adjacent to diabase bodies: siltstone in these rocks is recrystallized to hornfels, siliceous limestone in the Mescal is converted to serpentine and asbestos, and impure limetone and mudstone in the Mescal are replaced by iron ore and amphibole.

Rocks of the Apache group in the northern part of Gila County have been strongly affected by structural features associated with intrusion of diabase and also by faults and strong joint systems that are later than the diabase. One strong joint system consists of fractures that strike about N. $20^{\circ} \mathrm{E}$. and N. $70^{\circ} \mathrm{W}$., parallel to the principal trends of the uranium ore bodies.

Uranium in the Dripping Spring quartzite was originally discovered in 1950. By the summer of 1955 nearly a hundred deposits were known. All these deposits are in the silty upper member of the Dripping Spring, and most of them are between 100 and 130 feet above the base of the member. Both normal siltstone and siltstone recrystallized to hornfels adjacent to diabase are favorable host rocks.

The longest dimension of nearly all the deposits trends either north-northeast or west-northwest. The intermediate dimension is less than 20 feet in most deposits; this dimension ordinarily is vertical, but in some deposits it is parallel to the bedding. The short dimension is commonly less than 5 feet.

Uraninite is the primary uranium mineral in deposits near diabase. For the most part the host rock for these deposits is feldspar-rich siltstone recrystallized to hornfels. In unmetamorphosed siltstone the primary uranium occurs in uraninite and in several unidentified forms. 
Pyrite, marcasite, chalcopyrite, and, more rarely, galena and sphalerite are associated with nearly all the deposits. Pyrrhotite and molybdenite have been recognized only in deposits near or in metamorphosed siltstone and diabase.

Most of the secondary uranium minerals in weathered parts of the deposits are phosphates and silicates. They are associated with limonite, gypsum, secondary copper minerals, and hyalite.

The primary deposits are found along favorable beds and fractures near diabase contacts. They are parallel to structural features that have been characteristic of the Dripping Spring throughout its history.

The uranium deposits are believed to be genetically related to the diabase. Present evidence suggests that the deposits may have been formed by uraniumbearing hydrothermal solutions emitted by the diabase at a late stage in its differentiation.

\section{INTRODUCTION}

This report is a preliminary compilation of data gathered during the early stages of a study of the stratigraphy and uranium deposits of the Dripping Spring quartzite in Arizona. The object of the study is to improve the understanding of the localization and genesis of these deposits. The Dripping Spring is a formation in the Precambrian Apache group and crops out extensively in southeastern Arizona. About 100 uranium deposits had been discovered in the Dripping Spring by August 1955; nearly all of these are in Gila County, particularly in the Sierra Ancha and Mescal Mountains.

The work on which this report is based was directed toward deter. mining the geologic setting of the uranium deposits in order that guides to more profitable prospecting and mining could be suggested. To do this, exposures of Dripping Spring quartzite in the Sierra Ancha and Mescal Mountains regions (fig. 51) were examined both in the vicinity of explored uranium deposits and in places where high radioactivity had been detected. Also, detailed studies were made of several deposits, and geologic maps were made of two areas that included several of the more productive uranium deposits. The work was done on behalf of the Division of Raw Materials of the U. S. Atomic Energy Commission.

Both the Sierra Ancha and the Mescal Mountains regions are in the Mexican Highland part of the Basin and Range physiographic province as designated by Fenneman (1931). The Sierra Ancha region has steep-walled canyons and small plateaus surrounding the high, rugged northwest-trending Sierra Ancha range. Elevations range from about 2,200 feet in the Salt River valley to 7,700 feet at the highest point in the range. Principal drainage is southward toward the Salt River. The Mescal Mountains are a west-northwest-trending range of block-faulted mountains with dip slopes on the southwest side. Elevations in the region range from about 2,200 feet to nearly 6,600 feet; the lowest elevations are in the canyon of the Gila River where it cuts through the mountains. Good dirt roads provide access 


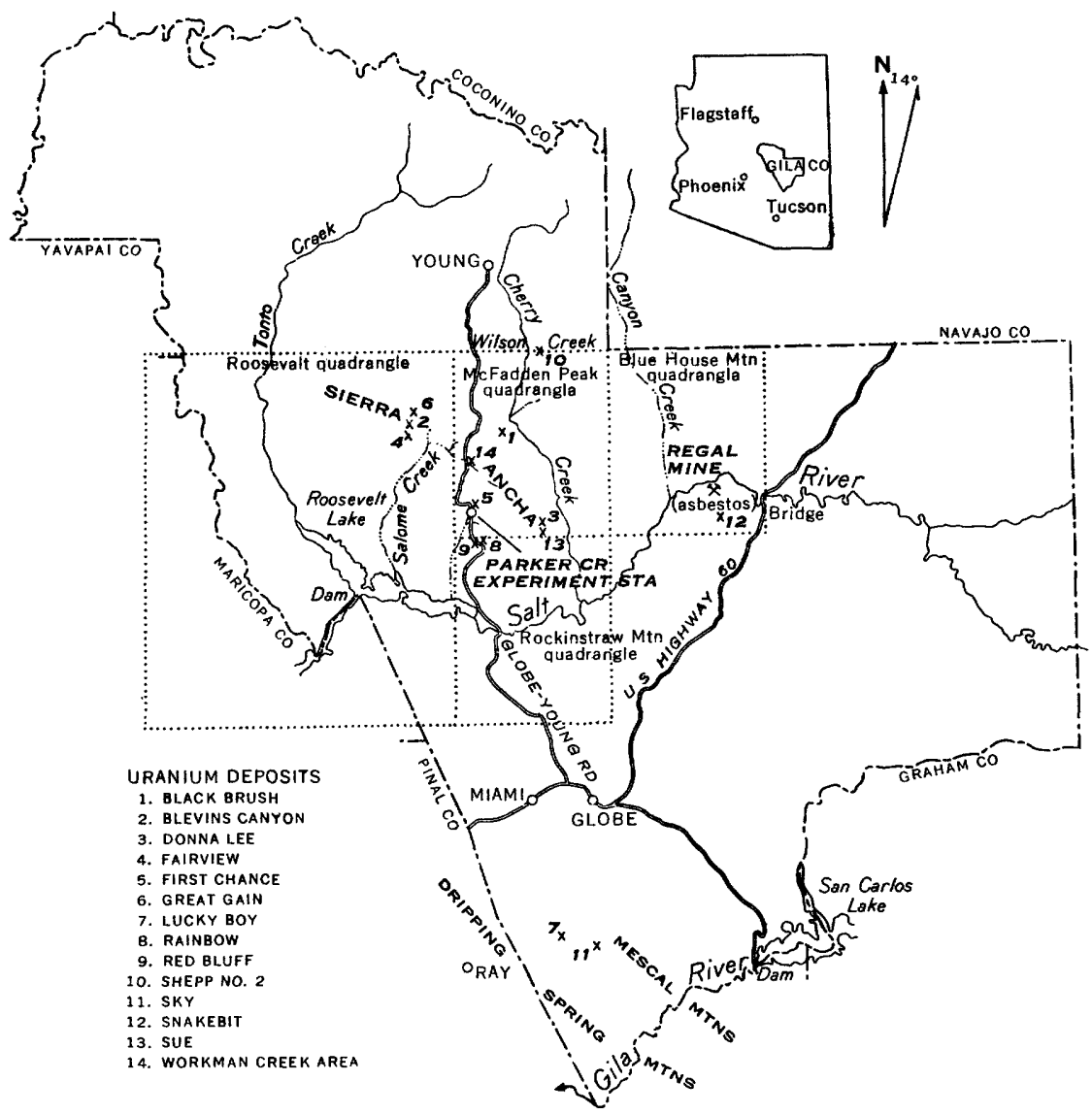

NOTE: Sierra Ancha region in Gila County is bounded by Ton to Creek on the west, Salt River on the south, and U.S. Highway 60 on the east. Mescal Mountains region includes just the Mescal Mountain range.

Fradre 51.-Index map of Gila County, Ariz.

to parts of both regions, but access to many of the deposits is possible only by vehicles with four-wheel drive.

Rain falls chiefly in July and August; snow is fairly common in the Sierra Ancha in the winter. Conifer forests at high elevations give way to catclaw, manzanita, and live oak in the lower, more arid slopes and canyon bottoms. On the dry slopes and mesas, juniper, mescal, yucca, and many varieties of cactus are the principal plants.

Previous work on uranium deposits in the Dripping Spring quartzite began with a brief preliminary examination of the Red Bluff deposit by R. J. Wright (1950) during the summer of 1950 . E. P. Kaiser (1951) made a more detailed study of the deposit and adjacent area in October 1950. In March 1953, W. E. Mead and R. L. Wells 
(1953) made a rapid field check of the radioactivity of the Dripping Spring quartzite in both Gila and Pinal Counties. Later in 1953 R. L. Wells and A. J. Rambosek (1954) reported on the newly discovered Stockman and Shepp claims in the northern part of the Sierra Ancha. R. G. Gastil ${ }^{1}$ mapped the east half of the Diamond Butte quadrangle and made a rapid study of the Apache group in Gila County. During 1954 and 1955 F. J. Williams studied the structural controls and related features of the uranium deposits in the Dripping Spring quartzite. His work was sponsored by the U.S. Atomic Energy Commission.

The writers wish to express their appreciation to the many geologists and mining men who have aided in the present study. R. A. Christman assisted the senior author for 2 months in 1954. A. F. Shride of the U. S. Geological Survey, presently mapping the McFadden Peak and Blue House Mountain quadrangles, provided much information on the geology of the Sierra Ancha region. R. J. Schwartz, U. S. Atomic Energy Commission, and F. J. Williams have provided the writers with a great deal of unpublished information.

\section{GENERAL GEOLOGY}

The Precambrian Pinal and Yavapai schists (Anderson, 1951, p. 1334) are the oldest rocks in Gila County. These rocks are overlain by mildly metamorphosed Precambrian sedimentary rocks in northern parts of the county (Wilson, 1922; Gastil ${ }^{1}$ ). Extensive bodies of granite, also Precambrian, intruded all the older rocks.

Sedimentary rocks of the Apache group of younger Precambrian age lie on an irregular surface cut in the granite and older rocks. They are disconformably overlain by a basalt flow which marks the end of recorded Precambrian deposition in this region.

The earliest rock of Paleozoic age is the Troy quartzite, which lies unconformably on the earlier rocks. Over most of Gila County it is underlain by either the Mescal limestone of the Apache group or basalt. Most of the younger Paleozoic rocks in the Sierra Ancha region have been removed by erosion except for local remnants of coarse sandstone that rest on the Troy. No age has been assigned to this sandstone (Shride, oral communication, 1954). On the southern slopes of the Mescal Mountains and in other parts of the county limestones of Paleozoic age overlie the Troy quartzite.

Loose to consolidated gravels of late Tertiary and Quaternary age are abundant in the intermontane basins and on the pediments. The most abundant of these is commonly called Gila conglomerate because of its similarity to the Gila conglomerate named by Gilbert (1875, p. 540-541).

${ }^{1}$ Gastil, R. G., 1953, The geology of the eastern half of the Diamond Butte quadrangle, Gila County, Arizona : Univ. Calif. doctoral thesis (unpublished). 
The Apache rocks and in some places Troy quartzite are extensively intruded by diabase. In general, the diabase bodies are sill like, but discordant contacts are common.

Igneous rocks of Cretaceous and Tertiary age are fairly common in Gila County but are largely absent in both the Mescal Mountains and the Sierra Ancha.

The Apache group and the rocks of Paleozoic age north of the Salt River valley in Gila County are nearly flat lying. Locally, block faulting and drag have produced steeper dips, but in general the structure is similar to that of the Colorado Plateau. South of the Salt River, however, the structure is of the basin-and-range type and has resulted in tilted block-faulted mountain ranges.

\section{ROCK DESCRIPTIONS}

Only the Apache group and the associated igneous and metamorphic rocks were examined. Descriptions of the sedimentary rocks are brief; for further information, the reader is referred to papers by Ransome (1903, 1916, 1919) and Darton (1925).

Descriptive data are based on the "Rock-Color Chart" (Goddard and others, 1948), the Wentworth grain-size scale, and terms proposed by McKee and Weir (1953) for describing layered rocks (see chart below). Rock colors were determined in the field by comparison with the chart. Grain size was determined in the field by comparison with a grain-size chart on which were cemented samples of clastic material corresponding to the grades in the Wentworth scale.

Quantitative terms used in describing layered rocks

[After McKee and Weir (1953)]

\begin{tabular}{|c|c|c|c|c|c|c|}
\hline & & & & Thic & ckness & \\
\hline & atification & Cross & -stratification & Centi- & Inches & Splitting property \\
\hline & Very thick-bedded & & $\begin{array}{l}\text { Very thickly cross- } \\
\text { bedded }\end{array}$ & $>120$ & $>48$ & Massive \\
\hline$d a$ & Thick-bedded & & $\begin{array}{l}\text { Thickly cross- } \\
\text { bedded }\end{array}$ & $120-60$ & $48-24$ & Blocky \\
\hline & Thin-bedded & & $\begin{array}{l}\text { Thinly cross- } \\
\text { bedded }\end{array}$ & $60-5$ & $24-2$ & Slabby \\
\hline & Very thin-bedded & & $\begin{array}{l}\text { Very thinly cross- } \\
\text { bedded }\end{array}$ & $5-1$ & $2-1 / 2$ & Flaggy \\
\hline Laminae & Laminated & Cross- & Cross-laminated & $1-0.2$ & $1 / 2-1 / 2$ & $\begin{array}{l}\text { Shaly (claystone, } \\
\text { siltstone) } \\
\text { Platy (sandstone, } \\
\text { limestone) }\end{array}$ \\
\hline & Thinly laminated & & $\begin{array}{l}\text { Thinly cross- } \\
\text { laminated }\end{array}$ & $<0.2$ & $<1 / 12$ & Papery \\
\hline
\end{tabular}




\section{SEDIMENTARY ROCKS OF THE APACHE GROUP}

The Precambrian Apache group consists of Scanlan conglomerate, Pioneer formation, Barnes conglomerate, Dripping Spring quartzite, and Mescal limestone, in order of decreasing age. The Apache group was named in 1903 by F. L. Ransome in his report on the Globe copper district. At that time he tentatively assigned a Cambrian age to the group and named the Scanlan conglomerate, Pioneer shale, Barnes conglomerate, and Dripping Spring quartzite; during mapping of the Ray quadrangle, Ransome (1916) added the Mescal limestone and Troy quartzite to the Apache group (fig. 52).

During his earlier mapping of the Globe quadrangle, Ransome had not recognized the Mescal and Troy and had included them with the Globe limestone and Dripping Spring quartzite, respectively.

The Troy was removed from the Apache group in the early 1930's (Darton, 1932) after Stoyanow (1930) found brachiopods of Middle Cambrian age in the Troy. Ransome in 1932 agreed with others (Reagan, 1903; Lee, 1905; Darton, 1925) that the restricted Apache group (below the Troy) is generally equivalent to the Unkar group (part of the Precambrian Grand Canyon series).

SCANLAN CONGLOMFRATE

The Scanlan conglomerate is at the base of the Apache group. It is composed predominantly of cobbles and pebbles of older Precambrian quartzite in an arkosic and purple shale matrix; vein quartz, red jasper, and schist pebbles and cobbles are fairly common. The Scanlan was deposited on a locally irregular surface of older Precambrian rocks. Where the Scanlan is absent, an arkosic facies of the Pioneer formation generally was deposited directly on the older rocks. The Scanlan conglomerate is as much as 155 feet thick ${ }^{2}$ put is generally between 10 and 25 feet.

\section{PIONEER FORMATION}

The Pioneer formation lies conformably on the Scanlan conglomorate. It contains arkose, orthoquartzite, sandstone, siltstone, and reddish-brown tuffaceous rocks. ${ }^{2}$ Elliptical spots bleached to buff, pale green, or pale red are typical features of the tuff and siltstone beds. The Pioneer is from 150 feet to more than 400 feet thick in most of the area described in this report, but the formation is absent in parts of the region to the north ${ }^{2}$ and in the southeast part of the Mescal Mountains (Darton, 1925, p. 30, 255).

* Gastil, R. G., 1953, op. cit. (see footnote, p. 418). 


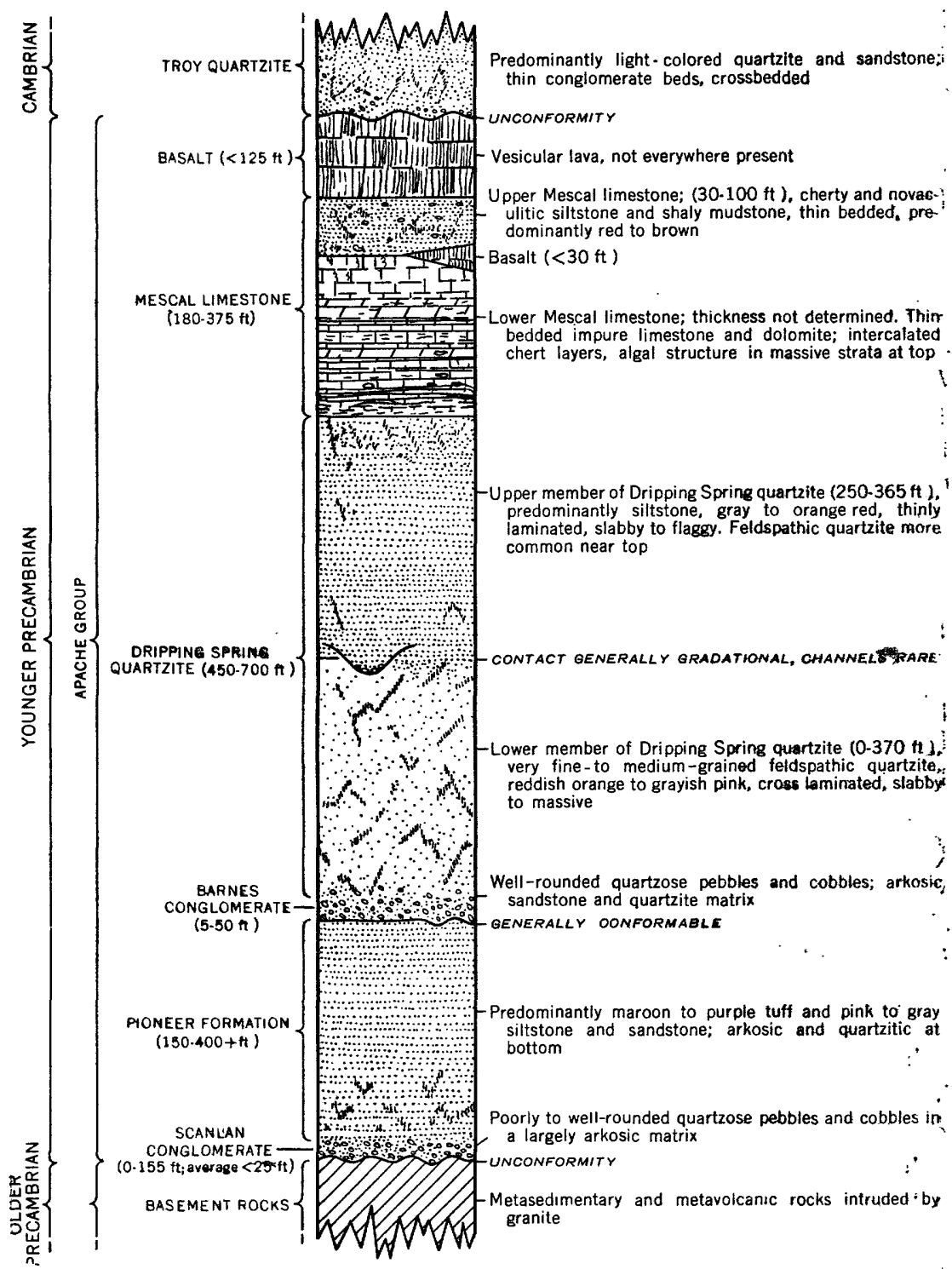

Figure 52.-Generalized columnar section of the Apache group, Glla County, Ariz.

\section{BARNES CONGLOMERATE}

The Barnes conglomerate conformably overlies the Pioneer for-' mation in most localities. To the north, however, Gastil ${ }^{3}$ refers to "angular(?) unconformities" having angles of as much as $30^{\circ}$ between the Pioneer and Barnes strata. The Barnes conglomerate is composed predominantly of well-rounded pebbles and cobbles ranging

${ }^{3}$ Gastil, R. G., 1953, op. cit. (see footnote, p. 418). 
from one quarter of an inch to 6 inches in diameter. Most of the fragments are older Precambrian quartzite with some red jasper and vein quartz pebbles. The matrix is moderately reddish-orange to reddish-brown arkosic sandstone or quartzite. Although the thickness is rarely more than 30 feet and commonly less than 15 feet, this formation is persistent throughout the area.

\section{DRIPPING SPRING QUARTZITE}

The Dripping Spring quartzite consists of feldspathic to arkosic sandstone, orthoquartzite, and arenaceous siltstone. In the Sierra Ancha region the thickness of the Dripping Spring quartzite ranges from 450 to 700 feet and averages about 600 feet. In the Mescal Mountains it ranges from about 450 feet (Ransome, 1919, p. 42) to 540 feet. $^{4}$

The Dripping Spring quartzite conformably overlies the Barnes conglomerate. In many places there is an abrupt change from the conglomerate to arkosic sandstone in the basal Dripping Spring. In some places, however, the basal strata of the Dripping Spring are conglomeratic arkose and here the contact must be arbitrarily placed. Locally, the Dripping Spring rests directly on the Pioneer formation or on buried hills of older Precambrian basement rocks. ${ }^{4}$ It is overlain conformably by the Mescal limestone.

The Dripping Spring is divided into an upper and a lower member (fig. 53). The lower member is typically feldspar-rich cross-stratified well-indurated sandstone; the upper member consists mostly of thinly stratified arenaceous siltstone. These distinctions are recognizable throughout Gila County.

\section{LOWER MEMBER}

The lower member conformably overlies the Barnes conglomerate. The basal strata are conglomeratic in some places, but the gravel rarely composes more than 25 percent of the rock.

The lower member is, in general, a very fine- to medium-grained arkosic to feldspathic cross-stratified sandstone. Feldspar is most abundant near the base, where it composes as much as 60 percent of the rock; it decreases upward, and near the top of the member constitutes as little as 5 percent of the rock. Most of the feldspar is moderate reddish orange, and the color of the fresh rock ranges from moderate reddish orange to grayish pink according to the abundance of feldspar.

A typical exposure of the lower member about $11 / 2$ miles northwest of the Red Bluff mine consists of 355 feet of very fine- to mediumgrained arkosic to feldspathic cross-stratified sandstone. The lower 32 feet is massive moderate-pink conglomeratic sandstone with a

\footnotetext{
4 Gastil, R. G., 1953, op. clt. (see footnote, p. 418).
} 


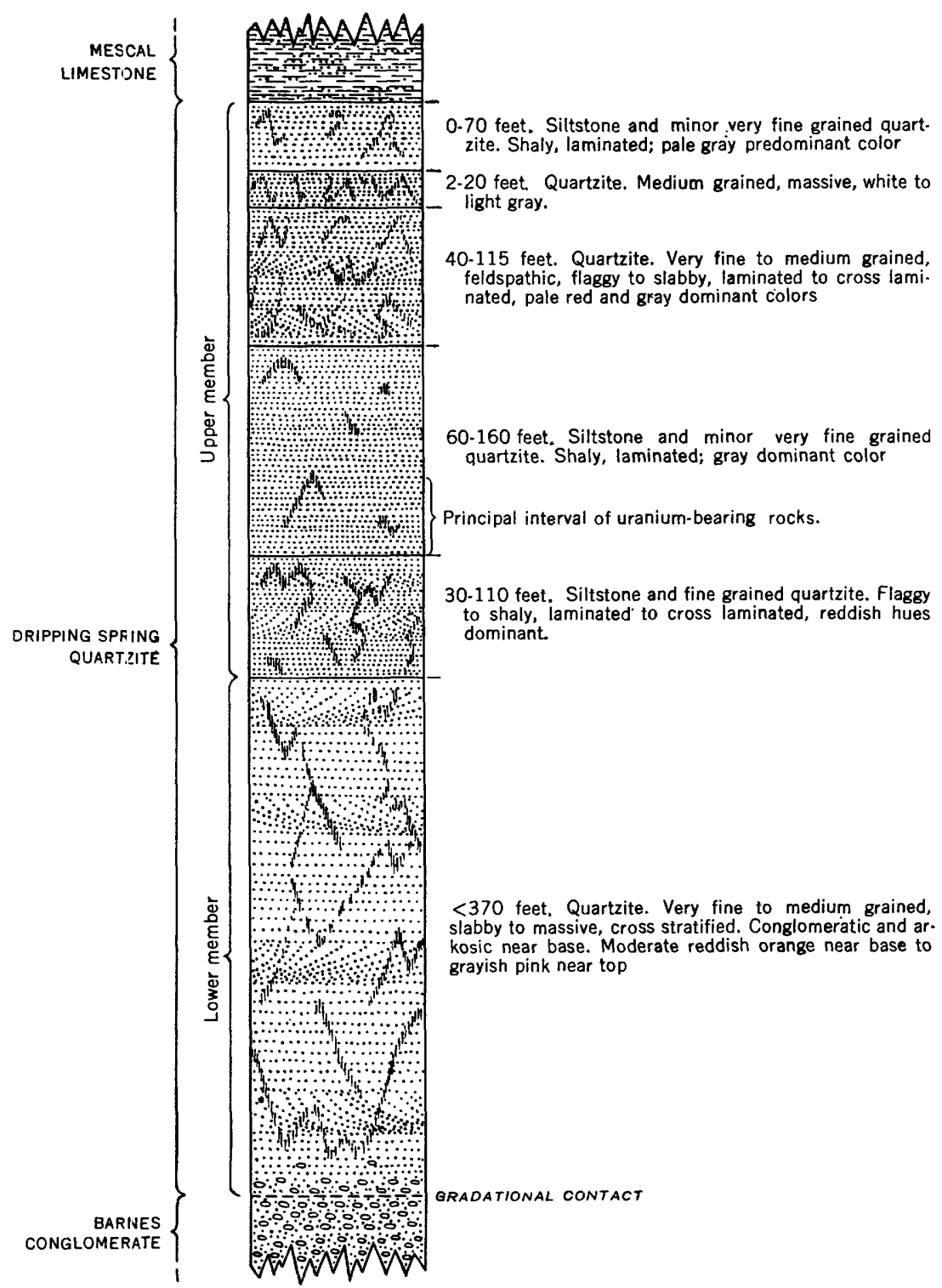

Figdre 53.--Generalized columnar section of the Dripping Spring quartzite, Slerra Ancha region, Arizona.

coarse- to medium-grained well-cemented arkosic matrix. Above this unit is 165 feet of blocky cross-stratified moderate to pale-red arkosic sandston 1 ; the grain size is mostly very fine, with interstratified fineand medium-grained beds near the top. Overlying this unit is 67 feet of feldspathic pale-red blocky sandstone. At the top of the member is 91 feet of grayish-pink medium- to fine-grained blocky orthoquartzite. In many places groups of strata near the top of the member are 
capped by nearly an inch of moderate-pink to light-red siliceous graded arenaceous siltstone, which is commonly ripple marked.

Weathered colors of the lower member are similar to the fresh colors but may be modified by bleaching and limonitic stains near the surface. The member typically forms cliffs which locally give way to ledges and slopes near the top.

The lower member is thickest in the southern part of the Sierra Ancha and at Roosevelt Dam, where it is 370 feet thick. It is missing in some places north and northwest of Young, Ariz."

Kaiser (1951) described a white quartzite member and Gastil ${ }^{4}$ defined the Lower Dripping Springs formation; these correspond to the lower member as described.

\section{UPPER MEMBER}

The base of the upper member is distinguished by three criteria: most of the strata are laminated and very thin bedded, in contrast to predominantly cross-stratified and structureless strata below the base; the rock is generally arenaceous siltstone, in contrast to underlying fine- or medium-grained sandstone; and mica is a common, though not abundant, constituent of the siltstone.

The upper and lower members are conformable, but rare paleochannels in the upper member may locally have been cut into the lower member. A paleochannel on the Blevins Canyon claims in the Roosevelt quadrangle cuts orthoquartzite that appears to belong to the lower member and is filled with interstratified feldspathic orthoquartzite and siltstone. It is about 50 feet deep and 700 feet wide at the outcrop. Another similar channel is about 15 feet deep where exposed at the confluence of Cherry Creek and China Spring Creek in the McFadden Peak quadrangle. These paleochannels were formed after the beginning of deposition of the upper member, as the uppermost strata cut by them apparently belong to the upper member.

A typical section in the Sierra Ancha may be divided into three major units that are overlain by a thinner orthoquartzite unit and capped by a few feet of arenaceous siltstone immediately below the Mescal (fig. 53). These major units do not have consistent thicknesses, and distinction among them is arbitrary in many places. In general the lowest unit is interstratified micaceous arenaceous siltstone and very fine grained arkosic sandstone; the siltstone is laminated, the sandstone is cross-laminated. Reddish hues are the dominant colors in the fresh rock. The middle unit is the host rock for most of the uranium deposits and is largely siltstone with a few persistent arkosic cross-laminated sandstone lenses. The siltstone ranges from very light to dark gray in the fresh rock. The unit forms a steep slope with smooth to hackly limonite-stained surfaces. The upper major unit is

4 Gastil, R. G., 1953, op. cit. (see footnote, p. 418). 
very fine- to medium-grained arkosic sandstone. The finer material is silty and very thin bedded; coarse grained strata are cross stratified. The dominant colors are pale reds and grays. This unit commonly forms cliffs or steep ledges and slopes.

Overlying the 3 major units is resistant sandstone as much as 20 feet thick. It ordinarily consists of relatively pure white mediumto coarse-grained cross-stratified orthoquartzite. In many places it forms a prominent white ledge that may be seen for several miles and is called the upper white quartzite marker (Kaiser, 1951).

Between this resistant sandstone and the Mescal there is generally a few feet of platy laminated arenaceous siltstone which forms a gentle slope covered with limonite-stained talus.

The potassium content of the upper member is greater than is normal for detrital sedimentary rocks. Six samples from the gray rocks in the middle unit contained an average of 10.2 percent $K$ (12.3 $\mathrm{K}_{2} \mathrm{O}$; see table 3). Most of this potassium is contained in authigenic feldspar and detrital grains of feldspar.

Ripple marks and shrinkage cracks are common below the upper white quartzite marker. Ripple marks are most abundant in the lower and upper major units. Shrinkage cracks which occur in the middle unit are usually distorted in cross section by differential compaction between the filling and the argillaceous siltstone in which the cracks formed.

Stylolites are abundant below the upper white quartzite marker, and are best developed in the upper major unit. The amplitude averages about 0.1 inch but ranges from small irregularities on bedding planes to nearly 0.75 inch. Most of the stylolites in the fresh rock are filled with pyrite. In the middle unit carbon is also concentrated in the stylolites. Oxidation of these minerals commonly gives a platy and locally banded appearance to outcrops that is not present in the fresh rock.

The upper member in the Sierra Ancha region ranges in thickness from 285 feet to 390 feet in 3 sections measured by Gastil ${ }^{5}$ and 9 sections measured by the writers of this paper. The thinnest sections are in the northern part ${ }^{5}$ and along the east margin (Reagan, 1932) of the Sierra Ancha. The upper member is more poorly known in the Mescal Mountains. Gastil ${ }^{5}$ reports about 380 feet in 1 section but results of the present study and descriptions by Ransome (1919, p. 42) suggest that the average thickness of the upper member in the Mescal Mountains is between 250 and 300 feet.

The upper member corresponds to the upper silty quartzite member and the Upper Dripping Springs formation described by Kaiser (1951) and Gastil, ${ }^{5}$ respectively.

5 Gastil, R. G., 1953, op. cit. (see footnote, p. 418).

$467515-59-3$ 


\section{MESCAL LIMESTONE}

The Mescal limestone overlies the Dripping Spring with apparent conformity in many places. Here the basal strata are composed of carbonate-bearing mudstone that is locally limonite stained. At other localities, however, the basal strata are composed of breccia consisting of dolomite and chert fragments in a siliceous dolomitic mudstone matrix. In these places the base of the Mescal lies on a planed surface at the top of the Dripping Spring.

The Mescal may be divided into two units of which the lower is characterized by dominantly carbonate-bearing strata and the upper is mostly siliceous siltstone. The upper unit, as far as is known, is present only in northern Gila County.

At the base of the lower Mescal is a few feet of mudstone or breccia, as described above. These rocks are overlain by a succession of limy, cherty, and siliceous dolomite strata in which much of the silica forms thin lenticular layers in the dolomite beds. At the top of the lower Mescal is a massive unit of dolomitic limestone that contains abundant algal structures. The lower Mescal is separated from the upper Mescal by a layer of basalt in some parts of the Sierra Ancha.

The upper Mescal is typically composed of siliceous siltstone, although some limestone beds may be interstratified. A chert or chert breccia stratum lies on the basalt layer in the Red Bluff area. Above this the upper Mescal is predominantly a deep-red banded siliceous siltstone. Where it is not removed by later erosion, a basalt flow overlies the Mescal.

The lower Mescal probably has an average thickness of about 225 feet; as much as 375 feet has been measured by Shride (written communication, 1955) in the Sierra Ancha, and similar thicknesses have been measured by Darton (1925, p. 251) and Galbraith ${ }^{6}$ south of the Sierra Ancha. The upper Mescal is probably less than 100 feet thick throughout the Sierra Ancha.

\section{IGNEOUS ROCKS}

BASALT

The Apache group is capped by basalt over most of the Sierra Ancha and Mescal Mountains regions. The basalt is as much as 125 feet thick and consists of more than 1 flow in many places. Erosion before deposition of the Troy locally removed the basalt, and the Troy lies directly on the Mescal.

The basalt is composed largely of a dense light-brownish-gray to dark-gray groundmass in which grayish-green amygdaloidal blebs are locally present. In 1 facies, wafer-thin andesine phenocrysts as much as 1 inch in diameter are common. Pyrite, specularite, and

\footnotetext{
${ }^{6}$ Galbraith, F. W., III, 1935, Geology of the Silver King area, Superior, Arizona : Univ. Ariz. doctoral thesis (unpublished).
} 
copper sulfide minerals are present in blebs and veinlets in some places.

A previously unreported layer of basalt as much as 30 feet thick between the lower and upper Mescal was mapped in the Red Bluff area (pl. 45). It is missing in some parts of the Sierra Ancha but is present in the northern part of the McFadden Peak quadrangle. The relation of the basalt layer to the enclosing rocks is obscured by strong weathering and it was not determined if it is intrusive or extrusive.

One thin section of the basalt layer from the Red Bluff area contains altered low-index plagioclase feldspar which cobaltinitrite tests proved to be potash rich. If this composition is persistent throughout, the rock should not properly be called basalt. The alkalic nature of this specimen may, however, be a metamorphic effect of the nearby diabase.

\section{DIABASE AND RELATED ROCKS}

Diabase sills and dikes are abundant in the Apache group. Locally they have intruded the Troy quartzite in the Sierra Ancha and perhaps in the Mescal Mountains (Darton, 1925, p. 254). The sills are a maximum of nearly 1,000 feet thick. Dikes are less abundant than sills and rarely exceed 200 feet in width. Although remarkably concordant for the most part, many of the sills are slightly discordant and in some places may abruptly change stratigraphic position.

The period of major diabase intrusion was before Devonian time. Devonian rocks lie on an erosion surface cut into diabase (A. F. Shride, oral communication, 1954) in the Salt River Canyon near Highway 60, and Troy quartzite of Cambrian age lies unconformably on diabase in the eastern part of the Mescal Mountains (Darton, 1925, p. 256).

Much younger diabase bodies have been reported by Ransome (1919, p. 56) and Peterson (Peterson, Gilbert, and Quick, 1951, p. 35), but these are probably minor in total volume and may be the feeders of some of the basalts of Tertiary or Quaternary age (Darton, 1925, p. 254).

Diabase, as the term is used in this report, is any basic igneous rock of approximate basaltic composition and with an ophitic or subophitic texture. The composition and texture of the diabase studied differ somewhat among the various bodies and to some extent within the same body. The composition generally ranges from about 45 to 70 percent plagioclase and 20 to 30 percent augite, and some diabase contains as much as 20 percent biotite and 20 percent olivine. Accessory minerals including ilmenite-magnetite, apatite, and zircon generally make up less than 10 percent of the rock.

The average composition of the plagioclase is in the labradorite range. Many specimens are zoned and range in composition from 
$\mathrm{An}_{75}$ in the centers to $\mathrm{An}_{35}$ at the rims; grains are commonly carlsbadalbite twinned and more rarely show pericline twin lamellae.

Alteration, perhaps largely deuteric, is common throughout the diabase. The plagioclase altered to sericite; the pyroxene either to aggregates of fibrous hornblende or chlorite, illite, and amphiboles; and the olivine to magnetite and fine-grained unidentified aggregates consisting in part of epidote minerals and serpentine.

The diabase differentiated into a variety of local facies ranging in texture from pegmatoid to aplitic. These facies, although present in the Mescal Mountains and elsewhere, were studied only in the Sierra Ancha region.

\section{PEGMATOID FACIES}

The pegmatoid facies generally occur within the diabase bodies as tabular masses near and concordant with the upper contacts of sills. Narrow dikes locally cut the diabase and less commonly extend a few feet into the enclosing rocks.

Within the Sierra Ancha region the pegmatoid facies that were studied are distinguished from the enclosing diabase by coarser grain size, lighter color, and high albite content. Some are equigranular and hypidiomorphic; others are porphyritic. They are most typically alkalic syenite, but varieties range from granite pegmatite and granophyre to monzonite.

The general appearance and mineral composition of the pegmatoid facies range widely. The most consistent characteristic is the abundance of white, greenish, or pink albite, although one specimen from the Workman Creek area contained calcic oligoclase. The pyroxene is generally augite, and it ranges from an essential to a varietal mineral. Some specimens contain little or no pyroxene but have abundant hornblende. Titaniferous magnetite may form as much as 30 percent of the rock but is generally an accessory mineral. Biotite and quartz are present in some specimens. Apatite needles are common and sphene is rare.

All the specimens are altered, perhaps in part deuterically. The pyroxene is altered to fibrous green hornblende and more rarely to epidote. The plagioclase is partly altered to sericite, chlorite, and clay minerals.

Coarse-grained syenitic and monzonitic rocks associated with diabase have previously been described in Gila County by Ransome (1903, p. 85; 1919, p. 54-55), Bishop, ${ }^{7}$ Bejnar, ${ }^{8}$ and Peterson, Gilbert, and Quick (1951, p. 34). In these rocks, however, the dominant feldspar has been identified as orthoclase; other writers (Gastil; ${ }^{9}$ Short

\footnotetext{
${ }^{7}$ Bishop, Ottey Manley, 1935, Geology and ore deposits of the Richmond Basin area, Gila County, Arizona : Univ. Arizona master's thesis, unpublished.

8 Bejnar, Waldemere, 1950, Geology of the Ruin Basin area, Gila County, Arizona : Univ. Arizona doctoral thesis, unpublished.

'Gastil, R. G., 1953, op. cit. (see footnote, p. 418).
} 
and others, 1943; Carpenter ${ }^{10}$ ) have described potash-rich facies of the diabase. It is noteworthy that all samples of the pegmatoid facies as described in this report were taken from diabase bodies near uranium deposits and that the dominant feldspar is sodic plagioclase rather than potash feldspar.

\section{APLITIC FACIES}

The aplitic facies occur as dikes with no consistent trend which cut the diabase and more rarely extend a few feet into the enclosing rocks. They have been noted in the diabase at several places in the McFadden Peak and Blue House Mountain quadrangles, and similar rocks a few miles north of Globe have been described by Bishop. ${ }^{11}$

Aplitic dikes that cut the Dripping Spring quartzite are not common; at least 6 occur in the Workman Creek area, where they are generally less than 2 feet wide and are rarely traceable for more than 100 feet. Several other localities where aplitic dikes cut the Dripping Spring have been noted by R. J. Schwartz and A. F. Shride (oral communications, 1954-55).

The aplitic facies are typically a leucocratic hypidiomorphic granular feldspathic rock. The grain size ranges from about $0.1 \mathrm{~mm}$ to 4.0 $\mathrm{mm}$ but is nearly equigranular throughout individual dikes. The textures are inconstant, especially where a dike cuts a contact between diabase and the enclosing rocks.

Within diabase bodies the aplitic facies are generally more than 85 percent albite and less than 15 percent (total) sphene, pyroxene, biotite, quartz, and apatite; opaque minerals make up less than 3 percent of the rock. The texture is hypidiomorphic to xenomorphic granular.

Where aplitic dikes intruded the Dripping Spring quartzite the albite is partly or completely replaced by potash feldspar; quartz is a major constituent and occurs as rounded grains or myrmekitic and micrographic intergrowths with the feldspar. The abrupt changes in composition and texture where aplitic dikes cross the contact between diabase and the Dripping Spring suggest that the dike-forming fluids have reacted with the wall rocks or with solutions derived from them.

\section{METAMORPHIC ROCKS}

\section{HORNFELS AND RELATHD ROCKS}

Hornfels has been produced by contact metamorphism of the upper member of the Dripping Spring and the upper Mescal at several places adjacent to diabase bodies. Hornfels is best developed in the Workman Creek area, where it is the host rock for the uranium deposits. Other localities noted are in the Red Bluff area about a mile north of the Red Bluff mine; along Pocket Creek in sec. 18, T. 5 N., R.

\footnotetext{
10 Carpenter, R. H., 1948, The geology and ore deposits of the Vekol Mountains, Pinal County, Arizona : Stanford Univ. doctoral thesis, unpublished.

11 Bishop, O. M., 1935, op. cit. (see footnote, p. 428).
} 
$14 \mathrm{E}$.; and just above the diabase contact on the Black Brush property. The only hornfels in the Mescal noted by the writers is just above the diabase contact about a mile southwest of the Red Bluff mine. Shride (oral communication, 1954) has noted similar hornfels in both formations at several other localities.

Three distinct rock facies can be distinguished within the contact metamorphic zone in the Workman Creek area. The most abundant facies are a normal pelitic hornfels; recrystallization of the pelitic hornfels has resulted in a coarser grained rock here called recrystallized hornfels; and where the recrystallized hornfels shows evidence of having moved as a fluid the authors call it a transition dike (this term is used to refer to a rock that has characteristics of both dikes and veins but does not have all the characteristics of either).

The pelitic hornfels is a dense aphanitic dark- to pinkish-gray rock that may be megascopically difficult to distinguish from the normal siltstone. The stratification is generally well preserved. In thin section the rock has a xenomorphic granular texture and an average grain size of about $0.1 \mathrm{~mm}$. Potash feldspar is the most abundant mineral, with lesser amounts of quartz, albite, biotite, pyroxene (augite?), sphene, and extremely fine grains of sulfide minerals which are disseminated throughout the feldspar and along grain boundaries.

The recrystallized hornfels is a crystalline pinkish or light-gray to dark-gray igneous-appearing rock of syenitic or granitic composition. Relict stratification is commonly well preserved. In thin section the rock has a xenomorphic to hypidiomorphic granular texture, and the grain size ranges from about 0.5 to $6.0 \mathrm{~mm}$. Untwinned potash feldspar makes up 70 to 95 percent of the rock. The feldspar is euhedral to anhedral, and the varietal and accessory minerals are developed along grain boundaries and in interstices between feldspar grains. Most specimens contain quartz, sphene, albite, and sulfides, but pyroxene and biotite may or may not be present. In the darker colored facies the sulfides occur as fine dust disseminated throughout the rock; in the lighter colored rocks the sulfides are localized as larger grains along grain boundaries and in interstices.

Most commonly the recrystallized hornfels occurs as layers 1 to 30 $\mathrm{mm}$ thick parallel to relict bedding in pelitic hornfels. The rocks may have a lit-par-lit appearance. The recrystallized hornfels also occurs as small, discrete, spherical aggregates about $3 \mathrm{~mm}$ in diameter developed along bedding planes and fractures in the pelitic hornfels. The feldspars have a xenomorphic texture along the margins of the aggregates, with euhedral grains facing a small vug in the center which may or may not be filled with quartz and sulfides. Where these small aggregates are very abundant they have coalesced to form the bands described above. In maximum development the recrystallized hornfels has replaced all the pelitic hornfels. 
The transition-dike material generally occurs as breccia cement. Narrow randomly oriented dikes a fraction of an inch to about a foot wide are common in and marginal to the breccia zones. Locally, the dikes and breccia are concordant with the relict bedding and form sill-like bodies. Uraninite-bearing deposits in the Workman Creek area commonly are parallel to north-northeast-trending zones of interconnected dikelets or breccia cemented by this rock. The transitiondike rock is nearly identical to that of recrystallized hornfels in composition and texture but may contain more quartz, less sphene, and larger aggregates of sulfide minerals. The texture suggests that the feldspar formed a porous mesh in which quartz and sulfides were deposited in the open spaces and partly replaced the adjacent feldspars along grain boundaries. The average grain size is slightly larger than that of the recrystallized hornfels, although the range in size is no greater.

Transition dikes commonly have nonmatching walls, pinch-andswell borders, and blunt terminations. Some dikelets appear to be wider between walls of recrystallized hornfels than in pelitic hornfels. Other dikelets, however, have sharp matching walls and uniform thickness for short distances. In breccia zones some fragments of hornfels have rounded outlines with gradational boundaries against the transitional dike material, whereas others are angular and have sharp contacts. Many of the fragments lack any orientation with relict stratification in the walls. These relations with the wall rocks, together with the textures, indicate that the transitional dikes were emplaced as a fluid in open spaces but locally reacted with and replaced the wall rocks.

Metamorphism of the sedimentary rocks to hornfels apparently entailed very little change in chemical composition. The normal rcck-forming elements in samples of both normal siltstone and hornfels are shown in table 1. Only potassium, sodium, calcium, and magnesium show any appreciable differences. These differences are greatest in samples from the Lucky Stop claims, but the reason for this is not known. Metamorphism from siltstone to hornfels has apparently resulted in loss of potassium and magnesium and gain of sodium and calcium. It is assumed that there may have been corresponding changes in the silicon and aluminum contents which would not show up in this type of analysis. The addition of sodium and perhaps calcium may be due to contributions from the sodic differentiates from the diabase. The magnesium content of the siltstone samples ranges so widely that little significance can be attached to its average value. Iron, titanium, and vanadium, which commonly are mobile under mineralizing and metamorphic conditions, are as abundant in the normal siltstone as in hornfels (fig. 54). 


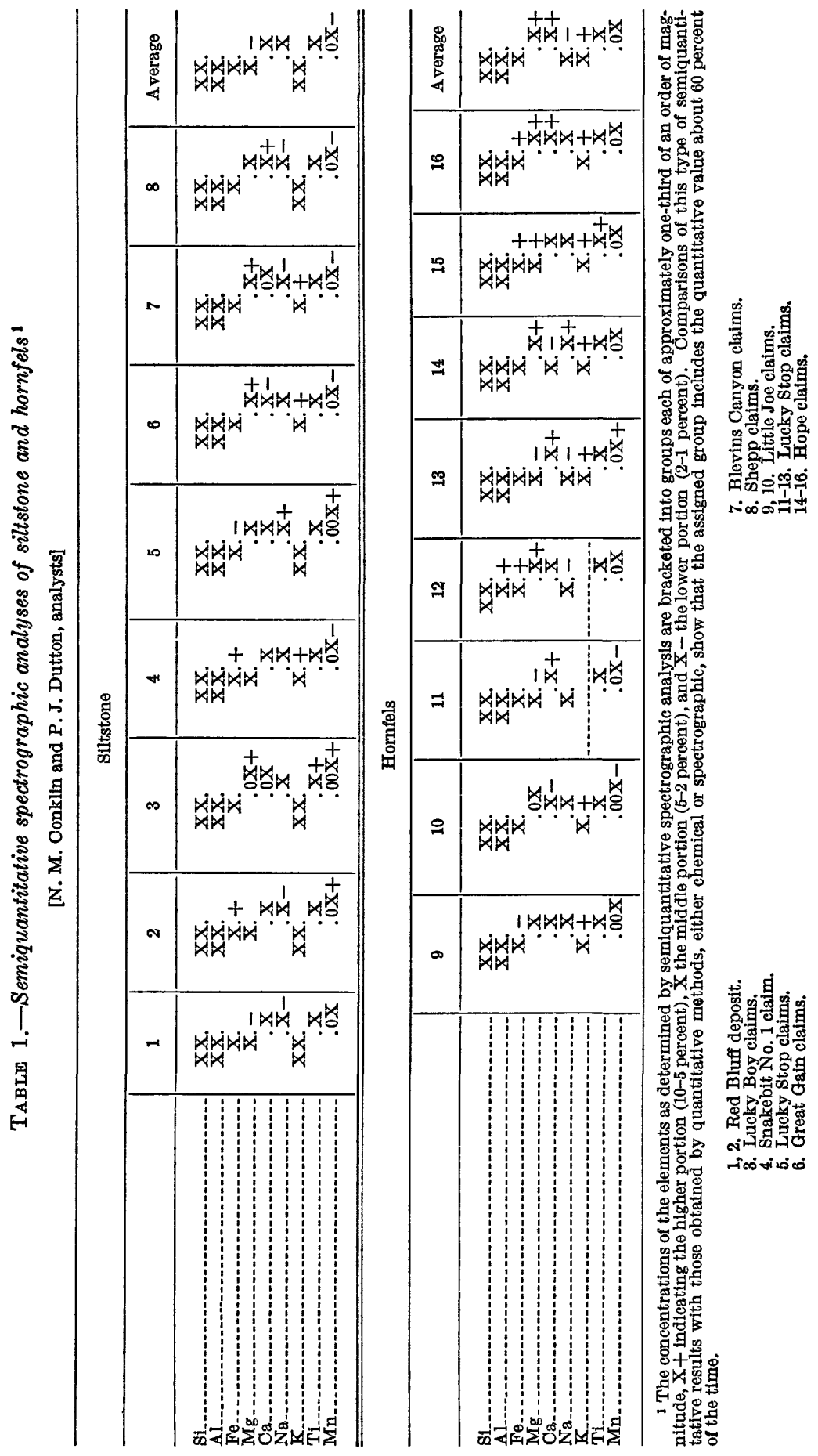



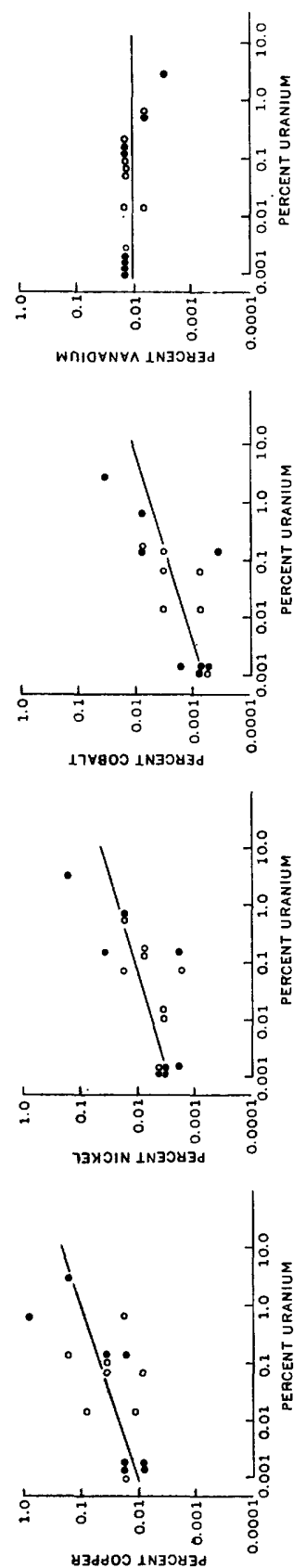
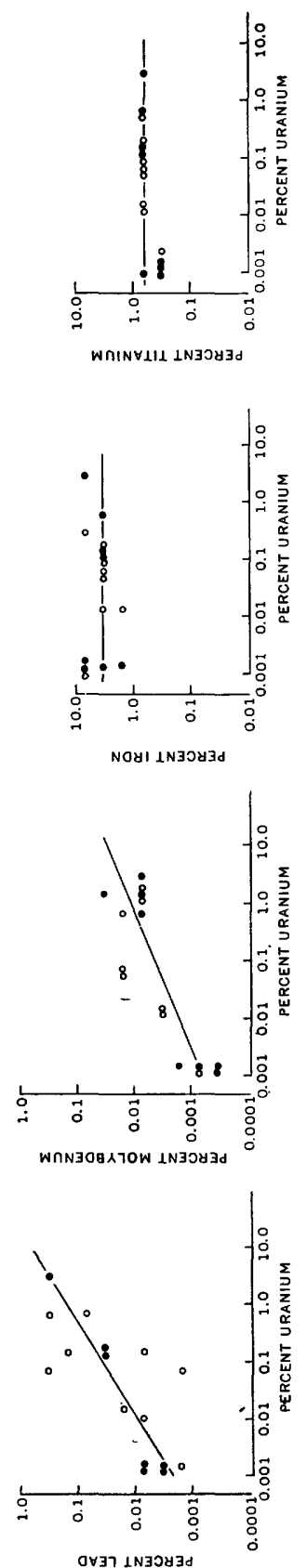

它导

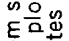

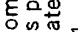
为呅

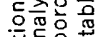

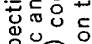

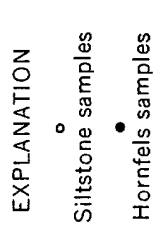
n.

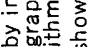
$\frac{1}{5}$

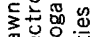

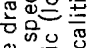

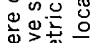
(a) 要

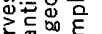

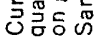
-i 봉

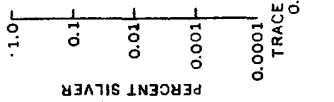


In summary, contact metamorphism of the upper member of the Dripping Spring in the Workman Creek area apparently recrystallized siltstone to pelitic hornfels, with very little change in composition. The pelitic hornfels was converted to coarser grained recrystallized hornfels where mineralizers, probably principally water, were available. Dilation along breccia and fracture zones allowed parts of the recrystallized hornfels to become fluid and fill the open spaces. Probably this fluid was more comparable to a hydrothermal solution than to a magma, and local reaction with the wall rocks resulted in gradational contacts. The cause of dilation is not known but may have been regional stresses, changes in volume during metamorphism, or adjustments around the cooling, shrinking diabase body.

Dikes of the aplitic facies of the diabase may, by reactions with solutions derived from the wall rocks, be nearly identical with the transition dikes where they have cut hornfels. One or more of the following differences, however, will generally distinguish transition dikes from aplitic dikes: (1) the transition dikes commonly form small irregularly shaped bodies or breccia-and-dike zones with northnortheast and west-northwest strikes, whereas the aplitic facies form parallel-walled dikes with random trends; (2) the transition dikes generally contain less than 30 percent quartz as compared with 20 to 60 percent in the aplitic facies where they cut hornfels; (3) quartz fills interstices between feldspars in the transition dikes but occurs as rounded grains or micrographic intergrowths with the feldspars in the aplitic facies; (4) the transition-dike material commonly cements breccia fragments, whereas breccia fragments are rare in dikes of the aplitic facies; and (5) several uranium deposits parallel transition dikes and breccia zones, whereas no abnormal radioactivity has been noted in the aplitic facies.

\section{SERPENTINE AND ASBESTOS}

Chrysotile-asbestos deposits in the Mescal limestone have been described by Bateman (1923), Allen and Butler (1921), Sampson (1924), Butler (1929), Wilson (1928), and Shride (1952).

Shride states that

Chrysotile occurs as cross-fiber veins that approximately parallel the bedding of the [Mescal] limestone. The host for the veins is serpentine which differentially replaced certain limestone beds.

Small-scale bedding-plane faults and thrust faults, probably the result of adjustment in the limestone when the diabase was intruded, constituted the most significant factor in determining the extent of the asbestos deposits.

Wilson $(1928$, p. 33) believes that

* * * the asbestos was deposited from mobile solutions which used * * * fissures as pathways of entry to such strata as were amenable to development of serpentine and asbestos ***. Probably a final emanation from the diabase magma brought about *** the development of the serpentine and asbestos. 
Sufficient magnesium and silicon for these minerals may have been derived wholly from the olivine of the diabase, or part of the magnesium may have been supplied by the Mescal dolomitic limestone.

Shride now believes (oral communication, 1954) that the host rocks, which are serpentine-bearing limestone, were siliceous dolomite before diabase intrusion. The silicon and magnesium in serpentine and chrysotile may, therefore, have been supplied in large part by the Mescal.

\section{IRON ORT AND AMPHIBOLES}

Magnetite has locally replaced certain limy and dolomitic siltstone and silty dolomite beds in the Mescal near or adjacent to diabase contacts. Antigorite, amphibole, pyroxene, and more rarely, garnets are associated with the magnetite. Dolomitic mudstone beds near the base of the Mescal are locally metamorphosed in part to fibrous actinolite adjacent to or near diabase contacts.

\section{STRUCTURE}

Rocks of the Apache group in Gila County have been affected by (1) structural features associated with, or accentuated by, intrusion of diabase; (2) faulting that followed intrusion of the diabase and which is much more prevalent in southern Gila County than in the Sierra Ancha; and (3) strong joint systems. Possibly each of these has had some effect on the uranium deposits.

Diabase intrusion was accompanied by or was preceded by strong faulting of the intruded rocks. Diabase dikes which intruded along faults are common. Abrupt thinning or termination of diabase sills at faults and discordant contacts in otherwise concordant diabase bodies indicate faulting before intrusion of the diabase.

In the Sierra Ancha, diabase is also associated with large northtrending monoclinal folds or drag structures. One such structural feature may be seen at several places along the Globe-Young road between the Parker Creek Experiment Station and Young. At Workman Creek it is breached and the road is in diabase (pl. 47).

East of the Globe-Young road the diabase intruded the upper member of the Dripping Spring quartzite, and west of the road, on Jack Mountain, it intruded the Pioneer even though the upper side of the sill is everywhere at about 6,000 feet. The predominantly easterly dip of the Pioneer is steepest on the east flank of Jack Mountain; the easterly dip of the upper member of the Dripping Spring is steepest in the most westerly outcrops. The horizon of intrusion of the diabase changed along a structural feature that represents either drag along a fault or a monoclinal fold breached by erosion.

A monoclinal or fault-dragged feature is exposed for several miles on the west side of lower Cherry Creek. In parts of this feature the Dripping Spring is vertical or slightly overturned. 
Although diabase sills are strikingly concordant for the most part, discordant contacts are fairly common. These range from minor local discordances to sharply discordant contacts along dikes and around large inclusions of the sedimentary rocks. The inclusions are commonest near major structural features. One such inclusion was mapped just south of Jack Mountain (pl. 47) on the trend of the monoclinal feature described in the preceding paragraph.

Faults that are younger than the diabase are rare in the Sierra Ancha but are extremely abundant in the southern part of Gila County. A series of strong northwest-striking faults in the Red Bluff area has displaced rocks similar to the Gila conglomerate (pl. 45). These faults and the numerous northwest-trending block faults in the Mescal Mountains are probably related to the periods of basin-andrange block faulting which occurred largely in middle Tertiary to Recent time.

Joints with diverse orientations are widespread in the rocks of the Sierra Ancha and Mescal Mountains regions. Only the joints in the upper member of the Dripping Spring quartzite, however, have been studied in detail; those cutting diabase received less attention, and those cutting the other rocks were given only cursory examination.

Most joints in the upper member are weak, cut only a few beds, and have a short strike length; the dips are generally steep. One joint system, however, is strong throughout the upper member in the Sierra Ancha region. The strikes of one set of the system average about N. $20^{\circ} \mathrm{E}$. and of the other about N. $70^{\circ} \mathrm{W}$. The dips are steep and the joints nearly perpendicular to the stratification in most places. Where the beds have been tilted by faults that are younger than the diabase as in the Red Bluff area, the joints have been tilted also. Where the tilt of the sedimentary rocks may be attributed largely to the intrusion of the diabase, however, as in the Workman Creek area, this joint system has nearly vertical dips at an acute angle to the bedding.

In many places there is evidence of movement along the N. $70^{\circ} \mathrm{W}$. set of joints. Striae on some of the mine walls at the Red Bluff mine indicate nearly horizontal displacement. The amount of movement can rarely be determined but was probably very minor. In the Shepp No. 2 mine gougy breccia zones have the same trend as the N. $70^{\circ} \mathrm{W}$. set of joints. Recognizable beds locally are offset vertically as much as 1 foot. Plunging slickensides indicate a maximum of about 2 feet of oblique slip. Some movement may also have affected the N. $20^{\circ}$ E. set of joints, but no evidence of displacement has been observed.

Possibly the displacement along joints may be related to Tertiary or later faulting. In the Red Bluff area, for example, the strongest joints, and those along which movement has occurred, are in the $\mathrm{N}$. $70^{\circ} \mathrm{W}$. set, which most nearly parallels nearby faults that are younger 
than the diabase. It should be stated that A. F. Shride (written communication) believes that many of the joints predate or were contemporaneous with diabase intrusion, and that movement along these joints was a result of dilation by diabase. As evidence he describes joints which have been intruded by diabase, forming dikes. It may be concluded that there were periods during which joints were formed both before and after intrusion of the diabase.

Many of the joints, particularly of the N. $70^{\circ}$ W.-N. $20^{\circ}$ E. system, are filled with calcite and iron sulfide minerals which are strongly oxidized to limonitic material near the surface. Several quartz veins as much as 10 feet wide near the Blevins Canyon claims in the Roosevelt quadrangle have a $\mathrm{N} .70^{\circ}-80^{\circ} \mathrm{W}$. strike and nearly vertical dip.

Subparallel structures that have somewhat the appearance of scourand-fill features are common in the lower parts of the upper member of the Dripping Spring at some localities, especially at the northeast end of the Sierra Ancha. In this paper they are tentatively referred to as pseudochannels. In cross section the pseudochannels range in size from less than 1 inch wide and 1 inch deep to as much as 8 feet wide and 4 feet deep. The lengths are generally indeterminate at outcrop but probably range from about 2 feet to 30 feet or more. Where well defined in cross section, the core or filling of the pseudochannels is light-colored siltstone or very fine grained sandstone with undisturbed, nearly horizontal lamination. Figure 55 shows several pseudochannels in cross section. The enclosing host strata are generally argillaceous or silty material. Along the sides of the pseudochannels these enclosing strata are downwarped and appear to have been

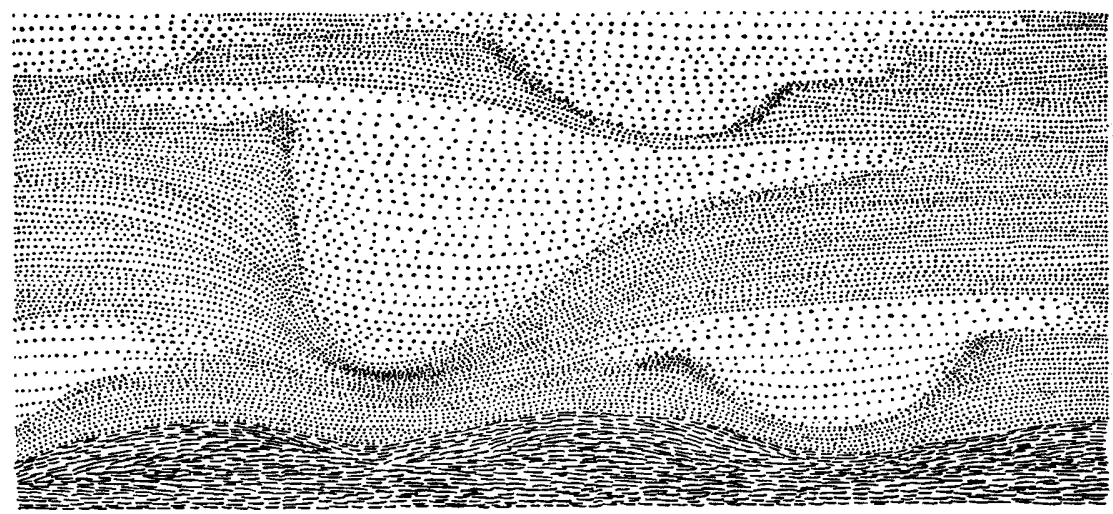

EXPLANATION

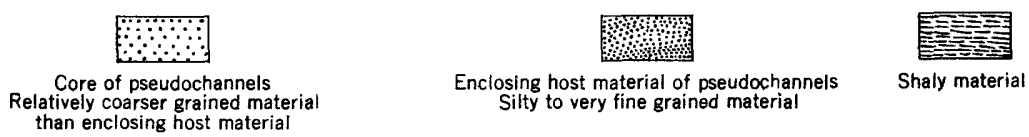

Cores range from an inch to more than 3 feet across.

Frgore 55.-Idealized cross section through pseudochannels. 
extended, thinned, and truncated by differential compaction against the core. In localities where pseudochannels are prevalent, this warping causes the rocks to appear to be folded in a series of open flexures with small amplitude.

The pseudochannels were evidently formed before consolidation of the rocks, but their mode of origin is not known. Differential compaction was important in their development, but what factors caused the shape and alinement of the cores is not yet known.

Weltlike striae on the bedding surfaces of the cores and adjacent rocks commonly are nearly perpendicular to the axes of the pseudochannels They are believed to have been caused either by differential movement or by healed tension joints that were better developed in the more competent material of the cores than in the enclosing siltstone and shale.

The predominant trend of the axes of the pseudochannels is $\mathrm{N} .15^{\circ}$ E. and that of the transverse striae about N. $70^{\circ} \mathrm{W}$. These trends are similar to the trends of the strong joint sets and the uranium ore bodies.

\section{RADIOACTIVITY}

Normal background gamma radioactivity of the Apache group and related rocks was measured by the U. S. Atomic Energy Commission during airborne reconnaissance of the Dripping Spring quartzite (Magleby and Mead, 1955). Measurements of some of these rocks were also made by the writers using a portable scintillation meter (table 2). The least radioactive rocks are diabase and the lower Mescal limestone. The most radioactive rocks are granite, the upper member of the Dripping Spring quartzite, and siltstone in the upper Mescal limestone. The radioactivity of the quartzite and upper Mescal is abnormally high compared to similar fine-grained sedimentary rocks elsewhere.

TABLE 2.-Radioactivity measurements of rocks in the Sierra Ancha

\begin{tabular}{|c|c|c|}
\hline Rock unit & $\begin{array}{l}\text { Measurements } \\
\text { from the air } 1 \\
\text { (microamperes) }\end{array}$ & $\begin{array}{l}\text { Measurements } \\
\text { on the ground } \\
\text { ( } \mathrm{mr} \text { per } \mathrm{hr} \text { ) }\end{array}$ \\
\hline Troy quartzite... & $125-200$ & \\
\hline Mescal limestone: & & \\
\hline Upper part ..... & $375-475$ & 0 \\
\hline $\begin{array}{l}\text { Lower part } \\
\text { Dripping Spring quartzite: }\end{array}$ & $125-150$ & $0.01-0.02$ \\
\hline Upper member & $375-475$ & $.03-.05$ \\
\hline $\begin{array}{l}\text { Lower member } \\
\text { Pioneer formation }\end{array}$ & $\begin{array}{l}250-350 \\
200-350\end{array}$ & $.02-.04$ \\
\hline Diabase & 100 & $01-.015$ \\
\hline Granite & $375-500$ & $\ldots \ldots$ \\
\hline
\end{tabular}

1 Measurements by Magleby and Mead (1955). Background over water is 75 microamperes.

2 Measurements at rock surface by the writers using a portable scintillation meter. 
To further study the radioactivity and uranium content of the upper member of the Dripping Spring quartzite, six relatively unweathered samples of the gray beds were collected for analyses (table 3). Two samples $(1,6)$ were from diamond-drill cores away from any known ore deposit, 1 was from normal siltstone more than 100 feet from a small uranium prospect, and the other 3 were in siltstone near known deposits of very low grade ore. The abnormally high potassium content of the upper member of the Dripping Spring is the cause of the generally high background radioactivity of these rocks.

TABLE 3.-Radioactivity of gray siltstone of the upper member of the Dripping Spring quartzite

[ $\mathrm{K}_{2} \mathrm{O}$ analyses by W. Mountjoy and I. Frost; Th analyses by radiochemical methods by $\mathrm{C}$. Angelo; U analyses by J. McClure; eU analyses by C. Angelo]

\begin{tabular}{|c|c|c|c|c|c|c|c|}
\hline \multirow[b]{2}{*}{ Sample } & \multirow{2}{*}{$\begin{array}{l}\text { Equiva- } \\
\text { lent } \\
\text { uranium } \\
\text { (percent) }\end{array}$} & \multirow{2}{*}{$\begin{array}{c}\text { Urani- } \\
\text { um } \\
\text { (per- } \\
\text { cent) }\end{array}$} & \multirow{2}{*}{$\begin{array}{c}\text { Thori- } \\
\text { um } 1 \\
\text { (percent) }\end{array}$} & \multirow{2}{*}{$\begin{array}{c}\mathrm{K}_{2} \mathrm{O} \\
\text { (per- } \\
\text { cent) }\end{array}$} & \multicolumn{2}{|c|}{ Potassium (percent) } & \multirow[b]{2}{*}{ Remarks } \\
\hline & & & & & $\begin{array}{l}\text { Calcu- } \\
\text { lated }\end{array}$ & $\begin{array}{l}\text { Equiva- } \\
\text { lent-ura- } \\
\text { nium } \\
\text { content }\end{array}$ & \\
\hline $1 .-$ & 0.010 & 0.002 & $<0.001$ & 10.5 & 12.1 & 0.004 & \multirow{6}{*}{$\begin{array}{l}\text { Diamond-drill core from a hole } \\
\text { near the Regal asbestos mine } \\
\text { Bluehouse Mountain quad- } \\
\text { rangle. } \\
\text { Above deposit on the Lucky } \\
\text { Stop claims. } \\
\text { Waste pile from the Shepp No. } \\
2 \text { deposit. } \\
\text { West haulage adit at the Sue } \\
\text { deposit. } \\
\text { 40 feet stratigraphically above } \\
\text { the Snakebit No. 1 deposit. } \\
\text { Diamond-drill core from hole } 8 \\
\text { on the Red Bluff claims. }\end{array}$} \\
\hline $3 \ldots$ & .033 & .029 & & 12.2 & 10.1 & .005 & \\
\hline 4 & .010 & .005 & 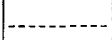 & 11.6 & 9.6 & .005 & \\
\hline 5 & .008 & .002 & -.....- & 12.6 & 10.5 & .005 & \\
\hline 6 & .006 & .002 & $<.001$ & 12.2 & 10.1 & .005 & \\
\hline A verage & 0.014 & 0.009 & $<0.001$ & 12.3 & 10.2 & 0.005 & \\
\hline
\end{tabular}

1 The radioactivity attributable to thorium is negligible. Hence if the uranium is in equilibrium with its daughter products, the following equation is true: $\mathrm{eU}(\mathrm{K})+\mathrm{U}=\mathrm{eU}$. Discrepancy between actual equiv. alent-uranium content and computed equivalent-uranium content is probably due to lack of equilibrium between uranium and its daughter products.

As can be seen from the table, the uranium content of siltstone little affected by uranium mineralization is no greater than 0.002 percent, which is not abnormal for carbonaceous siltstones. The excess radioactivity, which is equivalent on the average to about 0.005 percent uranium in equilibrium, is caused by the radioactive isotope of potassium, inasmuch as beta and gamma radioactivity emitted from a sample containing 2 percent potassium is about equal to that of the equilibrium products from 0.001 percent uranium (comparison used in U. S. Geological Survey laboratory, oral communication, John N. Rosholt, 1954).

\section{URANIUM DEPOSITS}

The original discovery of uranium in the Dripping Spring quartzite was made in February 1950 by Carl Larsen on his Red Bluff claims. The next discoveries were by Melvin Stockman and O. H. Shepp in 
the Wilson Creek area in January and February 1953. In March 1954 the U. S. Atomic Energy Commission started an airborne radioactivity survey of the Dripping Spring quartzite in selected areas (Magleby and Mead, 1955). Prospecting was greatly stimulated by this activity and many new deposits were discovered. By the summer of 1955 , nearly 100 deposits in the Dripping Spring had been examined by U. S. Atomic Energy Commission and U. S. Geological Survey geologists, and about 45 deposits were being explored and developed. About a dozen mines had stockpiled ore to be delivered to a buying depot being established 8 miles east of Globe.

\section{GENERAL DESCRIPTION}

All the uranium deposits in the Dripping Spring quartzite are in the upper member. Primary uranium minerals have been found only in the strata of the interval between 45 and 150 feet above the base of the member; the rocks in the interval between 100 and 130 feet have been the most productive.

Host rocks for the primary mineral deposits are most commonly flaggy, laminated, carbonaceous and pyritic siltstone and interstratified very fine grained sandstone. Hornfels is less common as the host rock, but ore deposits in the hornfels are ordinarily richer than those in normal siltstone.

The highest radioactivity in outcrops of the favorable strata is commonly adjacent to joints and fractures that trend within a few degrees of either N. $70^{\circ}$ W. or N. $20^{\circ}$ E. Most of these radioactive fractures are filled with limonite. At the Red Bluff mine they attain a maximum width of more than $11 / 2$ inches, and locally they contain vein quartz. The limonite is almost surely the result of strong oxidation of iron-bearing sulfide minerals in the fractures.

Mining has been governed by these fractures at most deposits; the common practice has been to follow the trend of a fracture that is abnormally radioactive at the surface. Not all fractures and joints that are abnormally radioactive at the surface contain radioactive minerals at depth. In some deposits the fracture that is exposed at the surface fades out with depth even though the ore body continues along the same trend (Rainbow 1 and Workman 1 adits); in others the fracture diverges from the trend of the ore body (Black Brush adit).

The shapes of the ore bodies are not well known. Both structural and stratigraphic controls can be demonstrated in several of the deposits. The structural controls cause them to be veinlike with a north-northeast or west-northwest trend. Stratigraphic controls cause some deposits to be manto shaped parallel to the stratification. Combined structural and stratigraphic controls cause some of the deposits to be plus-sign shaped in cross section. Where strueture is 
the dominant control, as in the Workman, Hope, and Rainbow deposits, the strike lengths are on the order of 100 feet or more; the mineable widths are generally less than 5 feet; and the vertical dimensions are intermediate between the two but generally closest to the width. Where stratigraphic controls are strongest, as at the Lucky Boy, Sky, Blevins Canyon, and Great Gain deposits, they are manto shaped. At the Black Brush deposit and in workings $A$ and $B$ at the Red Bluff mine, the ore bodies have trends typical of structurally controlled deposits, but certain favorable beds contain ore for 10 or more feet from the general axis of the deposit. These deposits have plus-sign shaped cross sections.

The trends of the primary deposits are subparallel to the trends of strong limonite-filled joints and of the pseudochannels and associated transverse striae previously described. Inasmuch as the deposits do not necessarily coincide with the limonite-filled fractures but are apparently governed by controls that predate these fractures, it may be significant that the deposits follow the same general trend as the pseudochannels.

The mineral assemblage of primary deposits near diabase differs from that in deposits farther away. Uraninite has been identified only in the deposits on the Black Brush and Red Bluff claims and in the Workman Creek area, all of which are near diabase bodies. Pyrrhotite and molybdenite are present only in the Workman Creek area and in the Black Brush deposit; these are in areas where the siltstone host rock has been metamorphosed above thick diabase sills. Pyrite, marcasite, chalcopyrite, and less abundant galena and sphalerite occur in nearly all the deposits and, with the exception of early pyrite, are paragenetically later than the pyrrhotite, molybdenite, and uraninite.

To compare the effects of mineralization on the two host rocks, siltstone and hornfels, a number of metallic elements were plotted against increasing values of uranium, and shown in figure 54. Copper, lead, nickel, cobalt, silver, molybdenum, and beryllium show a positive correlation with uranium content, but the iron, vanadium, and titanium contents are nearly constant in all samples analysed. The slopes of the curves are similar for both host rocks, suggesting that similar mineralizing processes affected each rock type. The differences in mineral assemblage in the two host rocks are, therefore, largely a matter of degree. The curves indicate, in addition, that rocks favorable for uranium deposition were also favorable for deposition of the other metallic elements.

\section{DEPOSITS IN SILTSTONE}

Most of the uranium deposits in the Dripping Spring quartzite are in the gray siltstone of the upper member. Arkosic sandstone beds locally contain ore minerals, and, in some localities on the western 
flank of the Sierra Ancha and in the Mescal Mountains, argillaceous beds at the base of the upper member contain secondary uranium minerals. Crumpled mud cracks are common in the host rock of several of the deposits (Rainbow, Sue, Donna Lee, Shepp No. 2). At many places a ledge-forming unit consisting of very fine- to coarsegrained sandstone is a few feet above or below a deposit (Rainbow, Donna Lee, Snakebit).

Kaiser (1951) proposed that the uranium deposits at Red Bluff are in rocks in 2 distinct 20 -foot stratigraphic intervals about 28 feet apart. The basal strata in these 2 favorable intervals are about 75 and 120 feet, respectively, above the base of the upper member. A black marker bed a few inches thick lies immediately above the strata in each of the intervals. Elsewhere in the Sierra Ancha region these black marker beds are missing or are so obscure that they are not recognizable. Similar beds have been recognized locally but in other stratigraphic positions (Mead and Wells, 1953, p. 6). Mining at the Red Bluff deposits disclosed that the intervals of favorable strata were not so well defined as was originally believed.

Most deposits in siltstone are near diabase bodies, but only a few border the diabase. No deposits are farther than one half mile from diabase. Where details of the nearby diabase contact can be seen it is generally discordant. Even if the contact is for the most part concordant, minor discordances are common near deposits.

The distribution of uranium and the shapes of most deposits suggest that the ore minerals were disseminated in the walls of very tight fractures. There is no evidence that any primary uranium-bearing minerals were deposited in open spaces. The ore bodies all have assay walls, and the richest ore is commonly near the middle of the reinshaped bodies.

Uraninite is the only primary mineral identified in the deposits in siltstone and has been found only at the Red Bluff deposit. It occurs as minute grains less than 10 microns in diameter disseminated in a nontronite-clay and chlorite matrix that has apparently replaced the detrital grains of the siltstone. Efforts to separate and identify uraninite in the siltstone of other deposits have not been successful.

Some of the primary uranium in many of the deposits may be in a collodial form adsorbed on clay minerals. Maurice Duel and Joseph Houston of the U. S. Geological Survey (Duel, 1956; Irving Breger and Maurice Duel, 1955; written communications) separated a sample from the Shepp No. 2 deposit into three fractions: organiccarbon, mineral, and middlings. The middlings fraction is presumably mostly clay minerals. Very little of the uranium was contained in the organic-carbon fraction. About equal weights of uranium were contained in the mineral and middlings fractions, but a much higher percentage of uranium was contained in the middlings 
fraction. Results of the analyses are tabulated below (uranium analyses by Esma Campbell, ash analyses by Alice Caemmerer).

\begin{tabular}{|c|c|c|c|c|c|c|}
\hline & \multirow{2}{*}{$\begin{array}{l}\text { Weight } \\
\text { (grams) }\end{array}$} & \multicolumn{2}{|c|}{ Uranium } & \multicolumn{2}{|c|}{ Carbon } & \multirow{2}{*}{$\begin{array}{c}\text { Ash (per- } \\
\text { cent }\end{array}$} \\
\hline & & Percent & Grams & Percent & Grams & \\
\hline Original sample_. & 100.0 & 0.080 & 0.080 & 1. 93 & 1. 93 & 98.0 \\
\hline $\begin{array}{l}\text { Fraction: } \\
\text { Organic carbon } \\
\text { Mineral_. } \\
\text { Middlings }\end{array}$ & $\begin{array}{l}\text { 75. } 0 \\
23.8\end{array}$ & $\begin{array}{l}<.04 \\
.045 \\
.15\end{array}$ & $\begin{array}{r}\mathrm{Tr} . \\
.034 \\
.036\end{array}$ & $\begin{array}{l}\text { 68. } 0 \\
\text { 1. } 09 \\
\text { 1. } 8\end{array}$ & $\begin{array}{l}.51 \\
.82 \\
.43\end{array}$ & $\begin{array}{l}22.0 \\
99.0 \\
96.4\end{array}$ \\
\hline $\begin{array}{l}\text { Loss from original } \\
\text { sample }\end{array}$ & .45 & 12. 50 & .010 & 8. 80 & .17 & --- \\
\hline
\end{tabular}

Although very little of the uranium was contained in the organiccarbon fraction of the above sample, fine-grained graphite from the Rainbow deposit was found to be uranium bearing. In several of the deposits no primary uranium-bearing minerals have been identified.

Autoradiographs of smooth surfaces of unweathered ore-bearing rock indicate that the distribution of uranium is only partly controlled in detail by laminations in the rock, and there is no direct relation to stylolites or to fractures later than the stylolites. An autoradiograph of a specimen from the Rainbow deposit indicates that an irregularly shaped zone of radioactive material is crossed by stylolites, light and dark gray laminae, and sulfide-filled fractures without distortion. An autoradiograph of a specimen from the Sue mine showed that a narrow veinlet was bcrdered by radioactive material, perhaps secondary. Pyrite-filled stylolites cut the veinlet and radioactive material, indicating that the pyrite and perhaps the stylolites postdate the veinlet and, by inference, the radioactive material.

Pyrite and perhaps marcasite are common in the host rock. Most of the pyrite is very finely disseminated, and much of it is probably derived from original iron and sulfur in the rock. The remainder fills fractures and stylolites and may represent chiefly redistribution of the disseminated pyrite. For example, the host rock on the west side of Warm Spring Canyon at Red Bluff is strongly bleached and contains a mesh of fine pyrite-filled veinlets. The total iron content in these rocks, however, is not appreciably different from that of unaltered rocks in the same stratigraphic interval nearby which are dark gray and contain few visible pyrite veinlets. Although many of the uranium deposits parallel limonite- and pyrite-filled fractures, the fractures are not known to contain primary uranium minerals and there is no evidence that deposition or redistribution of pyrite is genetically related to uranium deposition.

Chalcopyrite is commonly present, but galena and sphalerite are rare or in extremely small quantities. Minor amounts of chalcopyrite 
are found in fractures but not in stylolites. Disseminated chalcopyrite rarely occurs more than a few inches from a pyrite-filled joint. Galena and, very rarely, sphalerite are disseminated as microscopic or larger blebs along sulfide-filled fractures and bedding-plane joints.

In oxidized parts of the deposits, secondary uranium minerals coat many of the late fractures and bedding-plane surfaces. In some places they are disseminated in the host rock as interstitial filling and cement. The most common mineral is metatorbernite. Other secondary uranium minerals are bassetite, uranocircite, uranophane and beta-uranophane, and colorless to clear green uraniferous hyalite. A soft black opaque uranium mineral with conchoidal fracture and vitreous luster has not been identified. It has been seen on only one specimen from the Sue mine and occurs as a drusy fracture coating associated with uranocircite.

Limonite and gypsum are commonly associated with the secondary uranium minerals. Malachite, azurite, and, more rarely, chalcocite and covellite occur in the oxidized parts of some of the deposits. Small amounts of barite have been noted in some specimens.

Pyritization and clay alteration of the host rock is common in and near uranium deposits. The pyritization may be of more than one age; for example, at the Red Bluff mine pyrite veinlets cut fractures filled with limonite that presumably was derived from earlier pyrite.

Much of the pyrite probably represents redistribution of earlier pyrite, as the total iron content does not seem to vary with the uranium content. Clay is largely of the montmorillonite type, smaller amounts of illite are present, and kaolin minerals are scarce. The clay was identified by $\mathrm{X}$-ray powder pattern and $\mathrm{X}$-ray diffraction pattern, but it is chloritelike in thin section and is generally a pleochroic green platy aggregate with indices between 1.57 and 1.60. Presumably the range in colors and indices is caused by variations in iron content. The clay is interstitial and forms small blebs that have partly replaced the feldspar and quartz of the host rocks. Grains of primary uranium minerals, carbon, and, locally, some grains of pyrite that average less than 10 microns in diameter are disseminated in the aggregates.

Weathering has oxidized the sulfide minerals and bleached the nearsurface rock. Oxidation of pyrite in stylolitic bands produces the flagginess that is characteristic of the host rocks near the surface.

\section{DEPOSITS IN HORNFELS}

Uranium ore deposits in hornfels of the upper member of the Dripping Spring quartzite are known only in the Workman Creek area. Hornfels has also been seen in other places, but the only abnormal radioactivity noted was on the Grand View claims about 4 miles south of Workman Creek. The ore deposit on the Black Brush 
claims is a few feet above hornfels that formed at the contact with diabase.

Deposits in hornfels occupy about the same stratigraphic position as the deposits in normal siltstone. They are from about 130 to 150 feet above the base of the upper member. Strong radioactivity has been noted locally higher in the section, but no mining has been attempted.

All the deposits in the Workman Creek area are above a locally discordant diabase sill. Most of the deposits on the north side of Workman Creek are within a few feet above the sill; the deposits on the south side of the creek are as much as 75 feet above the contact. Minor discordances in the nearly concordant contact between the diabase sill and the quartzite were noted at the Workman 1 adit (fig. 66) and the Hope 1 adit (fig. 63). The sill also may be discordant below the Lost Dog and the Lucky Stop deposits. but a thick mantle of debris obscures the relations.

Limonite-filled joints of the N. $20^{\circ}$ E. and N. $70^{\circ}$ W. sets apparently did not control the emplacement of the primary ore bodies. Although the highest radioactivity near the surface is along these joints, it was found that the joints commonly fade out within 80 feet of the surface even if the strong radioactivity continues.

Transition dikes or structural features along which they are emplaced, on the other hand, apparently had some control locally over the ore bodies. The greatest concentrations of primary uranium minerals in the Workman Creek area are in hornfels adjacent to pinkish or pinkish-gray transition-dike material. This material occurs as discontinuous stringers ranging from $1 / 4$ to 1 inch in thickness and as narrow dikes and small sill-like bodies that contain numerous fragments of the hornfels. The transition-dike material in the Hope and Workman mines locally forms interconnected stringers that strike approximately $\mathrm{N}$. $25^{\circ} \mathrm{E}$. in a zone as much as $11 / 2$ feet wide. In places in these zones the hornfels is brecciated, and the transitiondike material is the cement. These zones and the zones of highest radioactivity coincide and were not mapped separately. In the Workman adit the transition dikes and breccia cement were traceable from the portal to about 60 feet into the adit; in the Hope adit the transition dikes and breccia cement were traceable to 325 feet and were mapped as the zone of highest radioactivity.

Smaller concentrations of primary uranium minerals in hornfels, however, may occur where no transition dikes are present. In the Workman adit, for example, a comparatively low-grade extension of the ore body in a north-northeast direction from 60 feet in from the portal to the face (fig. 66) is not related to a transition dike. Conversely, some transition-dike material is not associated with concen- 
trations of uranium minerals. These bodies are commonly sill-like, irregularly shaped, and pinkish to light gray. For example, the ore abruptly terminates where the ore body in the Hope adit splits into a sill-like form (fig. 63) 310 feet from the portal.

Inasmuch as ore bodies can occur where neither fractures nor transition dikes are present, other controlling factors must exist. These may be in large part obscure controls that cannot yet be adequately explained.

Uraninite is the dominant primary uranium mineral in these deposits. Coffinite, a black uranium silicate, has been identified in a specimen from the Workman 1 adit by $X$-ray powder pattern (L. R. Stieff, written communication, 1955), but it has not been distinguished from associated uraninite in polished sections. Most of the uraninite occurs in small lenticular and irregularly shaped masses along relict bedding planes in hornfels. However, veinlets and irregularly shaped masses transverse to the bedding are fairly common. Locally, uraninite-bearing veinlets cut the transition-dike rocks. Few individual veinlets or masses containing uraninite are continuous for much more than 6 inches; ore bodies are composed of a great many of these disconnected veinlets.

The uraninite-bearing veinlets are composed mostly of uraninite and nontronite or chlorite in various proportions. Uraninite commonly occurs as discrete grains that average less than 10 microns in diameter and are disseminated in a matrix of nontronite or chlorite and minute grains of feldspar and quartz which may be relics of unaltered host rock. In some specimens, cubes of galena generally less than 10 microns across are abundant among the uraninite grains. These are much more common in transverse veinlets than in uraninite aggregates that follow the bedding. Locally, small blebs of chalcopyrite, pyrrhotite, or marcasite have replaced some of the nontronite or chlorite and partly or completely surround several uraninite grains (fig. 56). The veinlets are for the most part less than one quarter of an inch thick.

The wall rock from one quarter of an inch to several inches outward from the uraninite masses is commonly altered to pleochroic green nontronite and chlorite. Chalcopyrite, pyrrhotite, marcasite, and galena may or may not be disseminated in the altered zone. Figure 57 is a diagrammatic sketch of a veinlet in the Hope adit, about 325 feet from the portal. Galena and marcasite are concentrated in the altered zone; the galena is generally closer to the uraninite veinlet.

In some places there is very little alteration adjacent to the uraninite-bearing veinlets and masses. Specimens from the Little Joe claims contain uraninite in microscopic bifurcating fractures es- 
sentially parallel to relict bedding in coarse-grained feldspathized rock. The wall rocks contain very little clay, but the fractures contain some iron-stained clay minerals associated with the uraninite.

The feldspathic wall rocks generally contain several percent of disseminated sulfide minerals; continuous veinlets are rare. Pyrrhotite is the most abundant mineral, but chalcopyrite and marcasite are common. Molybdenite is present but not abundant. Galena and sphalerite are rare; both occur as disseminated grains, and the galena also forms paper-thin veinlets. Individual blebs of these sulfides range from 0.1 to nearly $15 \mathrm{~mm}$ in diameter. They are generally either interstitial to the feldspar grains or occupy vuglike cavities that contain quartz and are bordered by euhedral feldspar grains.

Paragenetic relations suggest that uraninite formed before any of the sulfide minerals. Although the sulfides have not replaced the uraninite noticeably, they commonly surround grains or occupy the interstices between grains (fig. 56) in a manner that indicates later deposition.

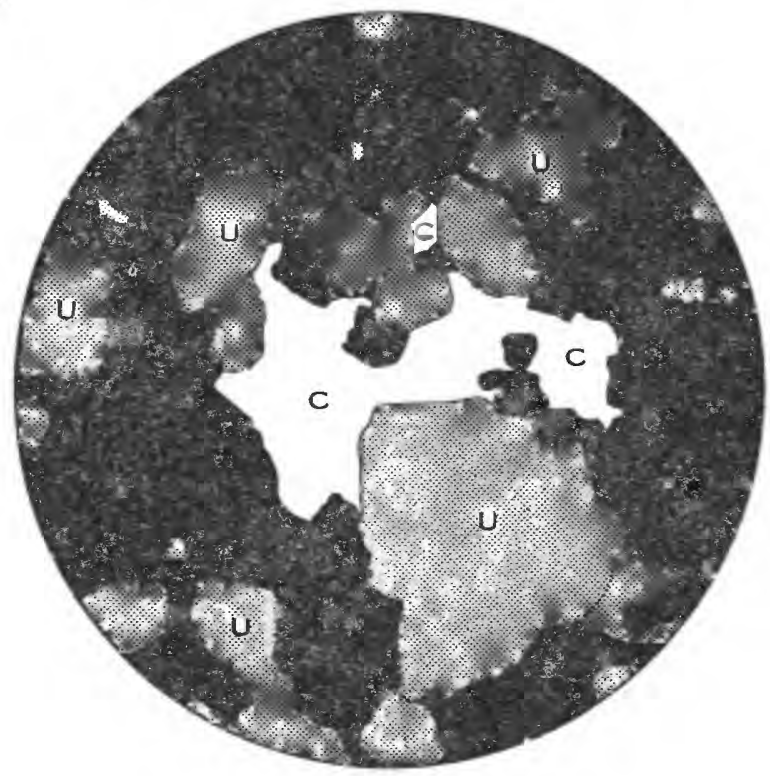

U-Uraninite

EXPLANATION

C-Chalcopyrite (marcasite and pyrrhotite were seen in similar relationship to uraninite)

Black-Gangue (principally feidspar, quartz, and green clay)

Sulfide minerals replaced gangue between disseminated grains of uraninite but did not noticeably replace uraninite Diameter of field $=0.13 \mathrm{~mm}$

FIGURE 56.-Camera-lucida drawing showing the relation of sulfide minerals to uraninite. (Subsequent analyses have shown that the green elay is a mixture of nontronite and chlorite.) 
Pyrrhotite and molybdenite were the earliest sulfides to form. Although some molybdenite flakes are partly or completely enclosed in pyrrhotite (fig. 58), they probably formed nearly contemporaneously. Chalcopyrite is later than pyrrhotite and locally replaced it, usually along grain boundaries. Figure 58 shows chalcopyrite that has replaced pyrrhotite along a thin flake of enclosed molybdenite.

Decomposition of some of the pyrrhotite has resulted in a banded form of marcasite. In some specimens, inclusions of chalcopyrite in former pyrrhotite are now isolated in marcasite. Nearly identical decomposition of pyrrhotite to marcasite is described by Edwards (1947, p. 100) and in ores from New South Wales by Stanton (1955, p. 692). Marcasite also occurs in veinlets and as fine lathlike grains disseminated near uraninite. The relation between these varieties of marcasite is not known.
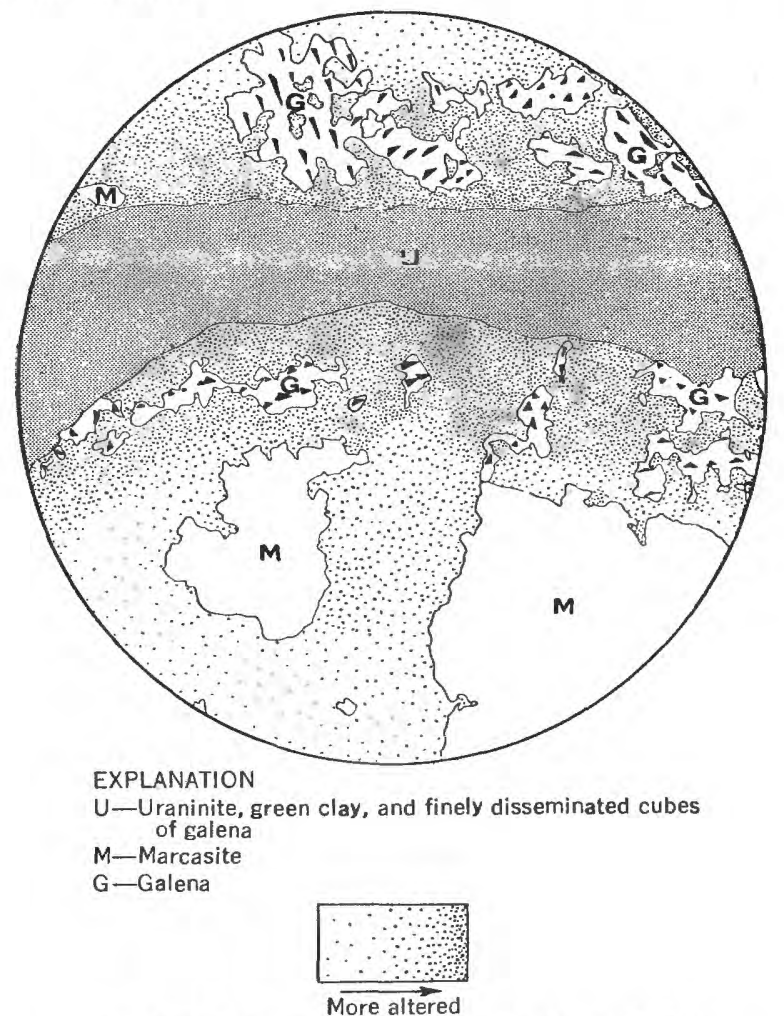

Host rock altered to green clay, showing degree of alteration

Uraninite-bearing veinlet fills narrow fissure in wall rock replaced by green clay and containing disseminated galena and marcasite; the galena commonly occurs closer to the veinlet than does the marcasite

Diameter of field $=2.4 \mathrm{~mm}$

Figure 57.-Camera-lucida drawing of uraninite-bearing velnlet. (Subsequent analyses have shown that the green clay is a mixture of nontronite and chlorite.) 
Galena and sphalerite are rarely present, and their relation to the other sulfides is not known.

Pyrite forms narrow veinlets in the host rock and is associated with calcite in unoxidized joints and fractures. At the Jon workings it forms flat rosettes and sheetlike coatings on argillized joint faces. It was not seen in contact with other sulfides.

The iron in pyrrhotite, chalcopyrite, marcasite, and pyrite was very likely derived in large part from original iron in the host rock. The iron content of 8 samples of hornfels and 8 samples of normal siltstone is remarkably uniform (fig. 54) even though there is a wide range in the degree of metamorphism and in the content of several nonferrous metals.

Near-surface oxidation effects induced by weathering extend to a depth of about 50 feet. In this zone most of the sulfides are oxidized, carbonates are leached from the veins, and much of the rock is bleached and iron stained.

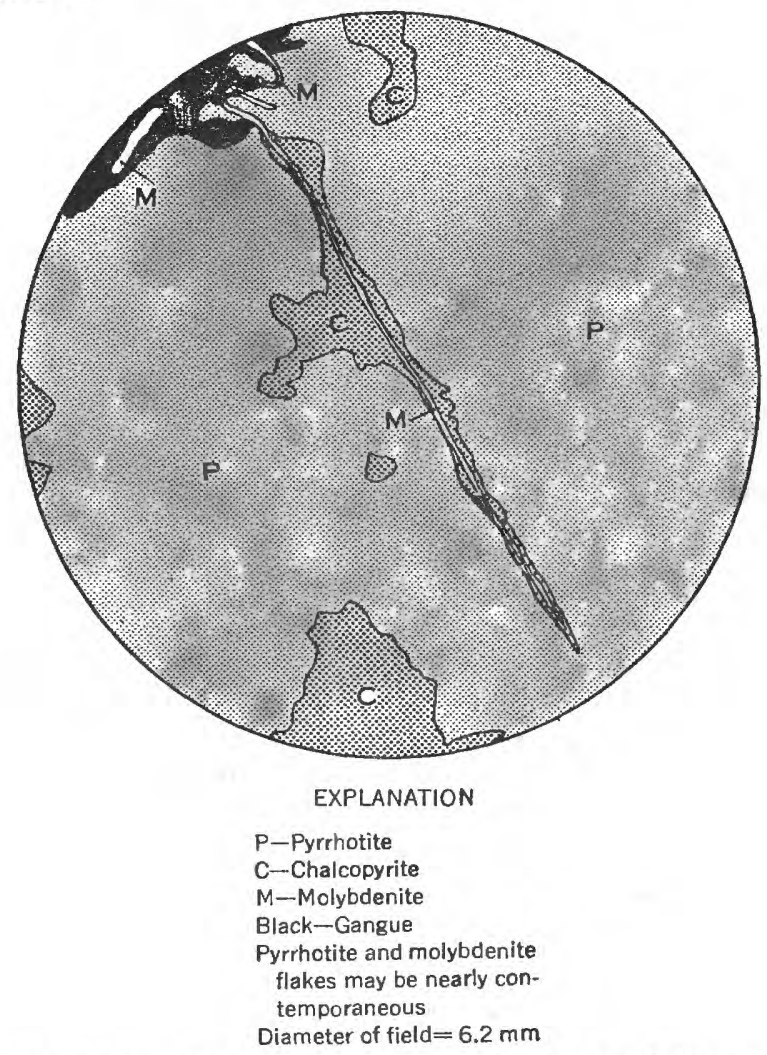

Frgure 58.-Camera-Iucida drawing showing pyrrhotite replaced by chalcopyrite adjacent to molybdenite. 
Secondary parts of the deposits in hornfels are similar to those in siltstone. The phosphate minerals, however, are rare; no uranocircite or bassetite was seen and metatorbernite is very scarce. The most common secondary uranium minerals are uranophane and betauranophane. Colorless to pale-green uraniferous hyalite is common along open fractures. The near-surface rock has abundant limonito stains, and both limonite and gypsum occupy fractures. Small quantities of malachite, chalcocite, and covellite are present in some places.

\section{ORIGIN AND ORE CONTROLS}

The origin and emplacement of primary uranium deposits in the Dripping Spring quartzite were evidently related to stratigraphy, structure, and diabase intrusive rocks. Stratigraphic controls presumably were due to the physical and chemical properties of certain strata within the formation. Structural features that probably resulted from regional stresses and perhaps from local stresses related to intrusion of the diabase controlled access and localization of the uranium. Heat and fluid emanations from the diabase may have provided the energy and, in large part, the media for transportation and distribution of the uranium-bearing materials.

The stratigraphic controls probably are largely a function of the chemical composition and, in smaller part, the permeability of the rocks. The abnormal carbon and sulfide content of the favorable strata in the upper member of the Dripping Spring must have created strong reducing conditions in the rocks at the time the uranium was deposited. Studies of ores from the Colorado Plateau suggest that reducing conditions due to the presence of carbon and sulfides were necessary for the formation of uraninite. Gruner $(1954$, p. 30) has noted that uraninite is found only with organic material or sulfides, especially pyrite. In all attempts to produce synthetic uraninite in the laboratory, Gruner has found that reducing conditions are essential.

Fracture control of many secondary deposits is evident, but structural control of the primary deposits is more obscure. Nearly all the deposits are elongated either north-northeastward or west-northwestward. These directions are identical with those of some transitiondike and breccia zones which are probably of about the same age as the uranium deposits. In addition, these directions are also the trends of pseudochannels in the host rock and of limonite-filled fractures that are younger than the uranium. These may be trends of weakness that have been a characteristic of the rocks since early in their history. The ore bodies probably were emplaced along very tight joints in most of the deposits, but locally, where the joints in competent rocks were subject to movement or intrusion, the deposits were emplaced along transition dikes and breccia zones. Calcite and pyrite are late min- 
erals in veins along these joints; the veins probably formed when the joints were reopened long after uranium deposition. Oxidation at the surface altered pyrite to limonite and removed the calcite.

The richest ore bodies are near diabase. Furthermore, there are mineralogic differences between deposits adjacent to diabase and those farther away. Sulfide minerals such as pyrite, marcasite, chalcopyrite, and, rarely, galena and sphalerite are found in all the deposits. These minerals are generally considered to have formed at low or medium temperatures. On the other hand, minerals generally considered to form at medium or high temperatures, such as pyrrhotite and molybdenite, are found only where the host rocks were affected by thermal metamorphism above thick diabase sills, as in the Workman Creek area and at the Black Brush deposit. Uraninite is readily identified in these and in the Red Bluff deposit, which is adjacent to a diabase dike. These relations strongly suggest that the uranium deposits were formed contemporaneously with cooling of diabase bodies.

Comparison of the uranium and asbestos deposits, which are the only other economic mineral deposits known in rocks of the Apache group in the Sierra Ancha region, suggests several genetic similarities. Trischka (1927) and Wilson (1928, p. 28-33) noted that the asbestos deposits in Gila County are closely related to the metamorphic effects of diabase on the Mescal limestone. Wilson concluded that late emanations from the diabase magma probably brought about the development of the serpentine and asbestos. Shride (oral communication, 1954) has found from extensive mapping that asbestos. deposits are localized in certain favorable beds near crosscutting diabase contacts, especially when there are many small fractures and faults. He believes that most of the magnesia and silica needed to. form the asbestos and serpentine was derived from cherty dolomitebeds.

Although it cannot be shown that all uranium deposits lie near or adjacent to diabase, as with asbestos deposits, it is notable that some of the richest uranium ore bodies are near discordant diabase contacts. The asbestos deposits and uranium deposits are similar in that both. occur within strata in certain stratigraphic intervals in an individual formation, both are probably contemporaneous with cooling of the diabase magma, and ore minerals are rare in the diabase even where adjacent to an ore body.

Despite evidence that the diabase is closely related to the uranium deposits, it should not be overlooked that later hydrothermal activity may have affected the deposits. The lead, zinc, and copper sulfides. may have been introduced much later than the uranium, and some. of the uranium may have been redistributed at this time. Uranium age determinations being conducted on these ores by the U. S. Geo- 
logical Survey will be seriously complicated if such a redistribution has taken place. If the uranium deposits and diabase are genetically related, it is probable that the uranium was derived either from the diabase magma or from redistribution of original uranium in the Dripping Spring quartzite.

If the uranium was derived from solutions released during the cooling of the diabase magma, it might be expected that chilled borders of the diabase would contain more uranium than the more slowly cooled interior parts of the diabase bodies. That is, the borders would be cooled so quickly that they would not enter into the differentiation processes and would retain a large part of their original uranium. The more slowly cooled interior would undergo partial differentiation and the normal coarse-grained diabase should contain somewhat less uranium if differentiated solutions were allowed to escape into the enclosing rocks.

To test this hypothesis, 6 samples of diabase from Warm Creek Canyon about 3,000 feet northeast of the Red Bluff mine were collected and anaylzed. Three samples of chilled diabase were taken 25 feet apart at the contact with the basal beds of the Mescal along the canyon floor. The other 3 samples, of normal diabase, were collected about 30 feet above each of the samples of chilled diabase.

The chilled-diabase samples contained an average of $0.72 \mathrm{ppm}$ (parts per million) (table 4), whereas the coarse-grained samples contained an average of $0.39 \mathrm{ppm}$ uranium. Averages of $0.62 \mathrm{ppm}$ and 0.32 ppm uranium, respectively, remained undissolved in a weak nitric acid bath for one-half hour at $80^{\circ}-85^{\circ} \mathrm{C}$. The undissolved uranium may represent uranium "tied-up" in some way by constituent rockforming minerals of the diabase.

TABLE 4.-Uranium content, in parts per million, of selected diabase samples 1

[Analyses by J. C. Antweiler; calculations by G. J. Neuerburg]

\begin{tabular}{|c|c|c|c|c|c|c|c|c|}
\hline \multirow{2}{*}{ Uranium content } & \multicolumn{4}{|c|}{ Chilled diabase? } & \multicolumn{4}{|c|}{ Normal diabase } \\
\hline & A 1 & A 2 & A 3 & A verage & Average & B 1 & B 2 & В 3 \\
\hline $\begin{array}{l}\text { Sample } \\
\text { Dissolved rock } \\
\text { Undissolved residue..... }\end{array}$ & $\begin{array}{r}0.89 \\
.11 \\
.78\end{array}$ & $\begin{array}{r}0.65 \\
.07 \\
.58\end{array}$ & $\begin{array}{r}0.63 \\
.13 \\
.50\end{array}$ & $\begin{array}{c}0.72+ \\
.10+ \\
.62\end{array}$ & $\begin{array}{l}0.39+ \\
.07+ \\
.32+\end{array}$ & $\begin{array}{r}0.42 \\
.07 \\
.35\end{array}$ & $\begin{array}{r}0.47 \\
.08 \\
.39\end{array}$ & $\begin{array}{r}0.29 \\
.06 \\
.23\end{array}$ \\
\hline
\end{tabular}

1 Samples from Warm Creek Canyon about 3,000 feet north of the Red Bluff mine.

Contact between diabase and lower Mescal limestone.

325 to 30 feet above each of the samples of chilled diabase.

4 Rock ground to -20 mesh and placed in $0.05 \mathrm{M}$ HNO $\mathrm{H}_{3}$ for $1 / 2$ hour at $80^{\circ}-85^{\circ} \mathrm{C}$.

The results, therefore, fit the hypothesis. It is possible, however, that the chilled border zone acquired its excess of uranium from the sedimentary rocks in contact with it. If this is so, the sedimentary rocks adjacent to the contact might contain less uranium than those farther away. This possibility has not yet been tested. 
If the uranium was derived from original constituents of the upper member of the Dripping Spring quartzite and redistributed by later processes, it might be expected that there would be a zone of lower uranium content in these rocks near known uranium deposits. To test this possibility would require a very detailed sampling program in completely unweathered rocks. No such sampling has been attempted, nor is it likely that it would be practicable.

\section{CONCLUSIONS}

The present study has led to the following conclusions:

1. Northern Gila County, the Sierra Ancha in particular, contains nearly all the uranium deposits in the Dripping Spring quartzite that are now believed to be favorable for the economic production of ore.

2. The upper member of the Dripping Spring quartzite is the most favorable host rock for uranium deposits in the Apache group.

3. The lower 150 feet of the upper member contains all uranium deposits known at present, and the strata in the interval between 100 feet and $\mathbf{1 3 0}$ feet from the base constitute the most favorable part of the member.

4. Outcrops of limonite-filled fractures that trend north-northeast or west-northwest are highly radioactive. Mining along these fractures commonly shows that the ore bodies are more persistent than the fractures, even though they have similar trends.

5. Most ore bodies are elongate in a north-northeast or west-northwest direction. They are generally lenticular in shape. The vertical dimension is ordinarily the intermediate axis; it is less than 20 feet long in all known deposits. The shorter horizontal dimension is about 1 to 5 feet, though unusually favorable beds may locally contain ore from much greater widths horizontally. The longer horizontal dimension is as much as 325 feet, but may be more in undeveloped deposits.

6. Most of the richest deposits are near diabase. Those in which uraninite has been readily identified are all within 100 feet of a diabase body.

7. The contact between the diabase and the upper member of the Dripping Spring is discordant near many deposits. There may be a relation between this discordance and the genesis of the deposits.

8. Some of the richest uranium deposits are in or near metamorphosed parts of the upper member. Fractured and brecciated parts of these rocks that are intruded by pinkish potassium-feldsparrich aplitic-textured transition dikes are especially favorable.

9. Major faults apparently had little, if any, control on the formation of ore deposits. Faults, however, may be spatially related in that they control the topography in such a way that more Dripping Spring is exposed near faults. 
The most successful method of exploring for new deposits has been with airborne or portable radiation-detection instruments. AIthough drilling for extensions of known deposits has achieved some success, drilling for new deposits has been unsuccessful for two reasons: the targets are generally too small, and the areas favorable for drilling are as yet too poorly defined.

\section{DESCRIPTION OF DEPOSTTS}

\section{RED BLUFF AREA}

The Red Bluff area (pl. 45) includes approximately 6 square miles surrounding the Red Bluff mine in the northwest corner of the Rockinstraw Mountain 15-minute quadrangle (fig. 51). The area is about 26 miles north of Globe on the Globe-Young road. The Red Bluff and Rainbow claims are the only developed uranium properties; two abandoned asbestos mines, however, are in the northeastern part of the area.

The Apache group is well exposed from the Barnes conglomerate to near the top of the Mescal limestone. Conglomerate similar to the Gila conglomerate is in fault contact with rocks of the Apache group in the southwestern part of the mapped area, and a mantle of talus debris locally covers all the rocks.

Diabase is widespread in the area. The main mass of diabase forms a thick sill in the upper member of the Dripping Spring northwest of the Red Bluff mine. East and northeast of the mine it intruded the Mescal limestone and terminates against east-dipping diabase-filled faults.

A previously unreported basalt layer was mapped between the upper and lower parts of Mescal limestone in the Red Bluff area. No conclusive relations could be found that would distinguish whether it is a sill or a flow deposited before deposition of the upper Mescal. Megascopically the basalt is similar to the basalt that commonly caps the Mescal. One thin section indicates that the basalt in the Red Bluff area is soda rich and contains albite and an unidentified melilite-like mineral. Cobaltinitrite tests show that the rock is rich in potassium. This specimen, however, was close to a diabase body and may not have been typical.

Metamorphism adjacent to diabase has resulted in three distinct changes in the rocks of the area: (1) serpentine, asbestos, and other silicates in the lower part of the Mescal near discordant diabase contacts in the northeast part of the mapped area; (2) hornfels and recrystallized hornfels in the upper Mescal just above a diabase body in the southwest part of the mapped area and in the upper member of the Dripping Spring adjacent to a narrow dike about 4,000 feet north of the Red Bluff mine; (3) a crystalline actinolite-rich rock in mudstone beds at the base of the Mescal where the above dike spreads out as a sill. 
Strong high-angle faults that are older and younger than the diabase cut the rocks in the Red Bluff area. Faults older than the diabase are at discordant diabase contacts and along dikes (section $A-A^{\prime}, \mathrm{pl}$. 45). The strikes of these faults are northerly, and the direction of drag in the Dripping Spring quartzite on the east side of the dike in Warm Creek Canyon (section $A-A^{\prime}, \mathrm{pl} .45$ ) is down toward the dike even though displacement on the fault shows that the west side was upthrown. This anomaly may have been caused by movement associated with diabase intrusion.

Faults younger than the diabase are in the northwest-trending fault zone that separates many of the earlier rocks from those similar to the Gila conglomerate. These block faults tilted the older rocks toward the northeast and serve to outline the basin that contains Roosevelt Lake to the southwest (fig. 51). Vast quantities of conglomerate similar to the Gila conglomerate were deposited in the basin. Movement along the faults doubtless continued during the deposition of the conglomerate; several of the exposed gouge-filled faults have well-consolidated conglomerate on the southwest and Dripping Spring on the northeast.

Joints of the N. $20^{\circ}$ E. and N. $70^{\circ} \mathrm{W}$. sets are prevalent in the area and are commonly filled with limonite at the surface. Where the strata dip about $6^{\circ} \mathrm{NE}$. near the Red Bluff mine, joints of the $\mathrm{N} .70^{\circ} \mathrm{W}$. set dip steeply southwest. Where the strata are nearly horizontal, however, the joints are nearly vertical. This suggests that the joints were formed before tilting of the rocks by faults younger than the diabase.

\section{RAINBOW DEPOSIT}

The Rainbow adit is in SE1/4 sec. 32, T. 5 N., R. 14 E., nearly a mile east of the Red Bluff mine (pl. 45). Access to the adit is by trail from an ungraded road above the deposit. The locator and owner of the 2 Rainbow claims is Mrs. Ethel S. Larsen, but the first lessee, the Sierra Ancha Mining Co., developed the property with the 70-foot adit that trends about $\mathrm{N} .15^{\circ} \mathrm{E}$. from a 45 -foot bench. In the spring of 1955 the property was under lease to the Uranium Corporation of America.

The Dripping Spring quartzite in the vicinity of the Rainbow adit strikes north-northwest and dips $3^{\circ}-5^{\circ}$ ENE. About 400 feet southwest of the adit a body of diabase is in discordant contact with the Dripping Spring (pl. 45). Fractures in the area are of the N. $20^{\circ}$ E. $-\mathrm{N} .70^{\circ} \mathrm{W}$. system and are commonly filled with as much as half an inch of limonite.

The host rocks for the deposit are slope-forming siltstone strata about 120 feet above the base of the upper member of the Dripping Spring. The siltstone is slabby to platy, very dark gray, and laminated. 
Crumpled mud cracks are common in the ore-bearing strata. Outcrops: of the rocks are bleached and are stained by iron oxides. Just below the portal fine-grained quartzite strata form a steep cliff.

The ore body trends about N. $15^{\circ} \mathrm{E}$. and has a vertical tabular shape. The total length of the ore body has not been determined, but it has been explored for about 80 feet. It ranges in width from about 1 foot to more than 3 feet in favorable strata. Where it crops out, the ore body is about 5 feet high. No stoping was done in the adit even though the ceiling and floor are locally radioactive.

The adit was started along a strong limonite-filled fracture (fig. 59), but this fracture becomes so indistinct as to be unmappable about 30 feet from the portal. However, the ore body continues at least 30 feet beyond the mappable limit of the fracture.

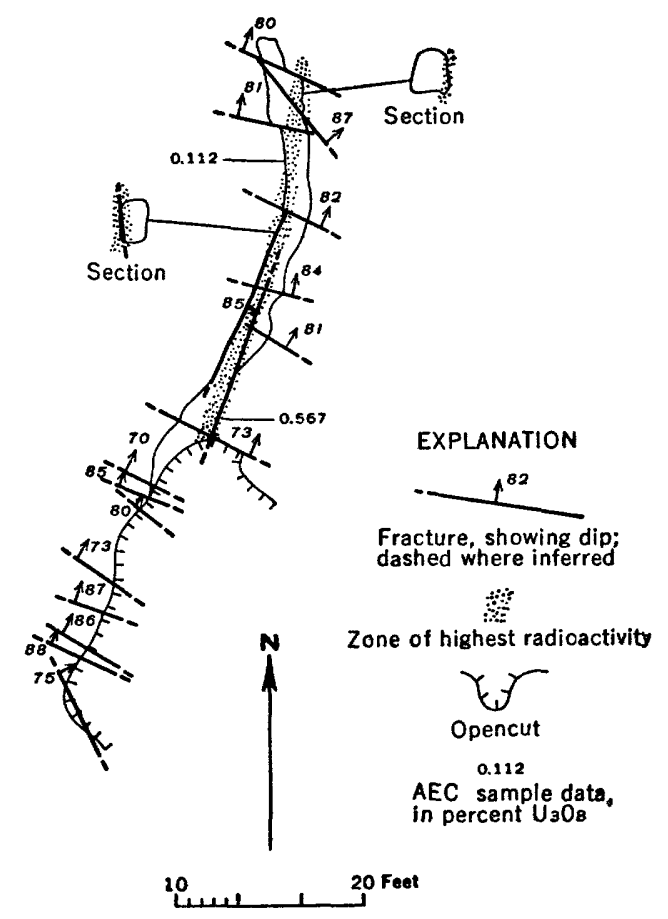

Figure 59.- Map and sections of the Rafnbow adit.

No primary uranium minerals were identified at the Rainbow deposit. A strongly radioactive mineralogic separate of graphite from near the face of the adit suggests that at least a part of the uranium may be associated with graphite and carbon. Metatorbernite was the only secondary uranium mineral noted in the deposit. It is associated with limonite and gypsum in fractures near the surface. 


\section{RED BLUFF DEPOSIT}

The Red Bluff mine is on the first known uranium deposit in the Dripping Spring quartzite and was discovered in February 1950. It is in the southeast corner of sec. 31, T. 5 N., R. 14 E., a few hundred feet from the Globe-Young road (fig. 51). The Red Bluff property consists of 15 claims owned by Carl and Ethel Larsen. During early stages of this examination the property was under option and being developed by the Sierra Ancha Mining Co. In early 1955 the property was held by the Uranium Corporation of America under an exploration agreement with the owners. The property is developed by five adits, a narrow opencut, and several prospect pits on the west side of Warm Creek Canyon. There are two adits on the east side of the canyon (pl. 46). The workings total about 1,400 feet in length.

The ore bodies are in the upper member of the Dripping Spring quartzite on both sides of a north-trending diabase dike in Warm Creek Canyon (pl. 46). The dike occupies a reverse fault that dips steeply west; the fault displacement is about 250 feet. The host rocks are dark-gray laminated siltstone and very fine-grained quartzite strata in the middle part of the upper member. On the west side of the canyon the rock has been very strongly bleached to a pale color. Bedding planes, joints, and a network of fine fractures are filled with pyrite stringers. On the east side of the canyon the rock is only weakly bleached and the pyrite is largely disseminated. The pyrite on both sides of the canyon is commonly oxidized, especially near the surface.

Two stratigraphic intervals of rocks favorable for the deposition of uranium have been recognized on the Red Bluff property (Kaiser, 1951). These are about 85 and 145 feet above the base of the upper member. The workings on the west side of the canyon are in strata in the lower interval, and the adits on the east side are in strata in the upper interval. On the west side of the canyon most of the strata in the upper interval have been removed by erosion. Drilling on the east side, however, has disclosed ore that may be in strata in the lower interval. These intervals of favorable rocks are not as well defined stratigraphically as was earlier supposed (Kaiser, 1951).

Most of the ore mined on the west side of the canyon was adjacent to strong limonite-filled fractures that strike about N. $70^{\circ} \mathrm{W}$. and dip nearly vertically. Favorable strata a few inches to several feet thick are locally ore bearing, and one ore body was stoped at the intersection of a fracture that strikes $\mathrm{N} .70^{\circ} \mathrm{W}$. and one that strikes N. $20^{\circ}$ E. A small amount of ore was localized along fractures that strike N. $20^{\circ} \mathrm{E}$. at the surface.

All the rock exposed in the workings on the east side of Warm Creek is abnormally radioactive, but material of ore grade is only 
locally present. There seems to be no relation between ore and fractures. Although a great many fractures that trend N. $70^{\circ} \mathrm{W}$. were intersected by the north adit, the best deposit of ore trended from the east wall of the south crosscut, through the intersection of the adit and crosscut, and into the west wall of the north crosscut (fig. 60). Almost no ore-grade material was cut by the south adit, although all the rock is abnormally radioactive.

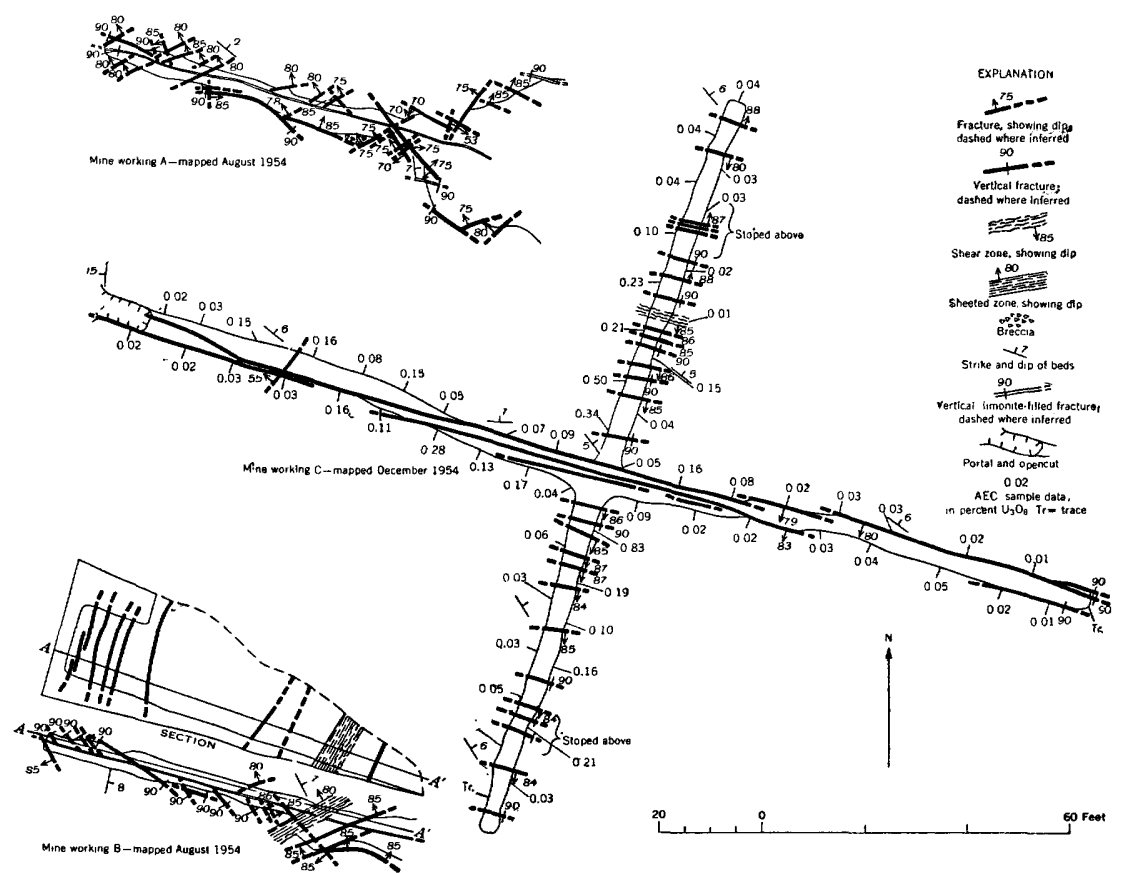

Figure 60.-Maps of mine workings A, B, and C, Red Bluff mine.

Primary minerals in the deposit are uraninite, pyrite, chalcopyrite, and galena. The uraninite is disseminated in the host rock. No uraninite was noted in fractures but some was tentatively identified along bedding planes. Pyrite is common in fine fractures on the west side of the canyon and is disseminated through the rock and occupies fractures on the east side of the canyon. Chalcopyrite is not abundant but locally is associated with pyrite. Galena is rare and is very finely disseminated along the fractures and bedding planes.

Uranium in weathered parts of the deposit occurs in the secondary minerals metatorbernite, bassetite, uranocircite, and uraniferous hyalite. These minerals generally coat fractures and bedding planes but locally are disseminated in leached host rock. The secondary uranium-bearing minerals are associated with gypsum, limonite, and minor amounts of malachite. Pleochroic green nontronite or chlorite 
is common in the deposit and locally is closely associated with the strongest radioactivity. The dark color of small highly radioactive parts of the deposit is largely due to the abundance of this material.

Chip-channel samples from the walls of the north-adit workings were gathered by personnel of the U. S. Atomic Energy Commission on the east side of Warm Creek Canyon (fig. 60). The other workings were not sampled. Radioactivity in the workings ranges from about $0.2 \mathrm{mr}$ per $\mathrm{hr}$ (milliroentgens per hour) to more than $5.0 \mathrm{mr}$ per $\mathrm{hr}$ as measured with a portable scintillation meter. The radioactivity of ore-grade material is generally more than $3.0 \mathrm{mr}$ per $\mathrm{hr}$.

\section{BULL CANYON AREA}

SUE DEPOSTT

The Sue deposit is in the SW1/4 sec. 19 (unsurveyed), T. 5 N., R. 15 E., and the SE $1 / 4$ sec. 24, T. 5 N., R. 14 E., in the McFadden Peak 15-minute quadrangle. The 21 Sue claims are owned by the Arizona Globe Uranium Co. of Globe, Ariz. The deposit had been developed by nearly 800 feet of workings in June 1955 (fig. 61). A 195-foot east adit and a 115-foot west adit constitute the lower level, and a 210 -foot drift nearly parallel to the adits forms the upper level. The levels are about 7 to 9 feet apart. Raises and about 260 feet of crosscuts connect these workings.

The deposit is exposed on a steep north-facing slope about 500 feet above the floor of steep-walled Bull Canyon. The topography is plateaulike; nearly flat-lying strata are dissected by deep, rugged canyons.

Rocks of the Apache group from the Scanlan conglomerate through the lower part of the Mescal limestone are exposed in the area. A north-trending fault about one-eighth of a mile east of the deposit has a vertical displacement of about 300 feet, with the upthrown side on the east. Locally, diabase may have been intruded along the fault, it may also have intruded the Mescal limestone above the deposits. If any such sill ever existed, it has been removed from this area by erosion. Several miles north of the mine such a sill is exposed.

The deposit is in nearly horizontal strata in the upper member of the Dripping Spring quartzite about 95 to 110 feet above the lower member. The top of a ledge-forming unit in the upper member is about 135 feet above the lower member and about 25 to 40 feet above the deposit.

The host rocks for the deposit are medium- to light-gray siltstone and very fine grained arkosic quartzite with interstratified lenses of white to grayish-pink fine-grained quartzite. Stylolites are abundant in the finer grained rocks and locally between the siltstone and finegrained quartzite. Much of the host rock in the mine is bleached and 
strongly iron stained, especially near fractures and in certain stratigraphic intervals. For example, rocks near the floor of the upper level are generally more iron stained than those near the ceiling of the level.

The radioactive material is distributed discontinuously in a northnortheasterly direction. Although the limonite-filled fractures are

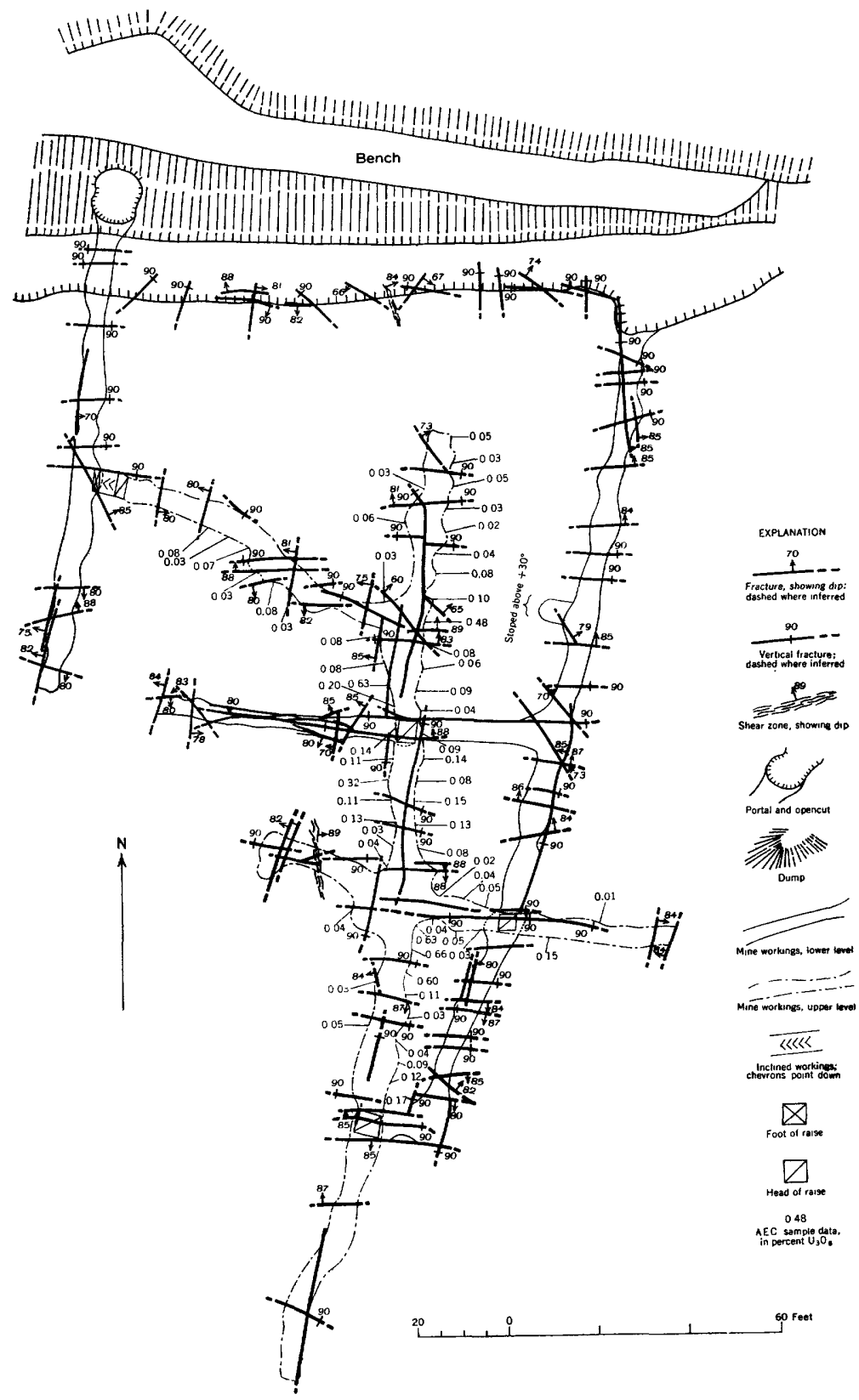

Figure 61.-Composite map of the Sue mine. 
parallel to the overall trend, the strongly radioactive rock is not in or parallel to any one fracture or group of fractures for a significant distance. Some individual beds as much as 3 inches thick are locally radioactive, and some weak and very discontinuous joints that strike in various directions are abnormally radioactive. Radioactivity is highest near the ceilling of the adits and near the floors of the upperlevel drift, but no individual bed or group of beds is of ore grade throughout the mine. The upper-level drift contains the most radioactive material exposed in the mine.

No primary ore minerals were identified in samples from the Sue mine. The secondary ore minerals metatorbernite and bassetite are abundant, and uranocircite is more sparingly present. The secondary ore minerals most commonly coat fracture surfaces in association with limonite and gypsum, but locally they are disseminated in the host rock.

More than 50 samples from the Sue mine have been collected by personnel of the U. S. Atomic Energy Commission (fig. 61). The samples range in grade from 0.01 to 0.66 percent $\mathrm{U}_{3} \mathrm{O}_{8}$. Uranium in samples analyzed chemically was very nearly in equilibrium.

\section{DONNA LFE DEPOSIT}

The Donna Lee deposit is in the SE1/4 sec. 13, T. 5 N., R. 14 E., in the McFadden Peak 15-minute quadrangle (fig. 51). Access to the property is from the Sue mine to the south by an ungraded dirt road suitable only for 4-wheel-drive vehicles. The property consists of 15 claims owned and deveioped by the Miami Copper Co. Development consists of two adits about a quarter of a mile apart on the southwest side of the steep-walled canyon of Deep Creek. The northern adit trends S. $22^{\circ}$ W. for 90 feet; in June 1955 a crosscut from the end of the adit had been extended southeastward for about 20 feet. The southern adit (fig. 62 ) trends S. $10^{\circ} \mathrm{W}$. for 85 feet.

The flat-lying Dripping Spring quartzite is overlain by remnants of the lower part of the Mescal limestone in the vicinity of the Donna Lee claims. The same north-trending fault that passes east of the Sue mine is exposed on the east side of the Deep Creek canyon. It has a vertical displacement of about 300 feet, downthrown on the west side. A small amount of diabase may locally follow the fault, but the nearest large body of diabase was probably a sill in the Mescal above the Dripping Spring.

The deposits are in strongly weathered and oxidized gray siltstone and very fine grained sandstone in the upper member of the Dripping Spring. A fine-grained ledge-forming unit about 145 feet above the lower member is 15 or 20 feet below the southern adit and about 12 feet above the northern adit. Crumpled mud cracks are common in rocks from the southern adit. 


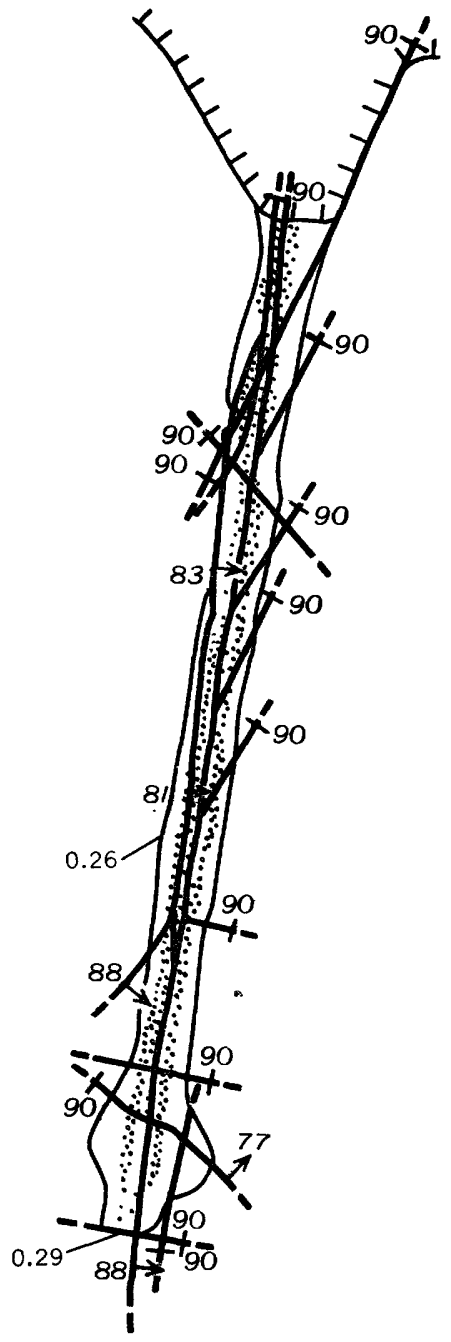

EXPLANATION

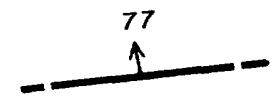

Fracture, showing dip; dashed where inferred

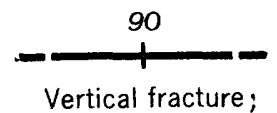
dashed where inferred

Zone of highest radioactivity:

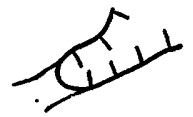

Portal and opencut.

0.26

AEC sample data; in percent $\mathrm{U}_{3} \mathrm{O}_{8}$,
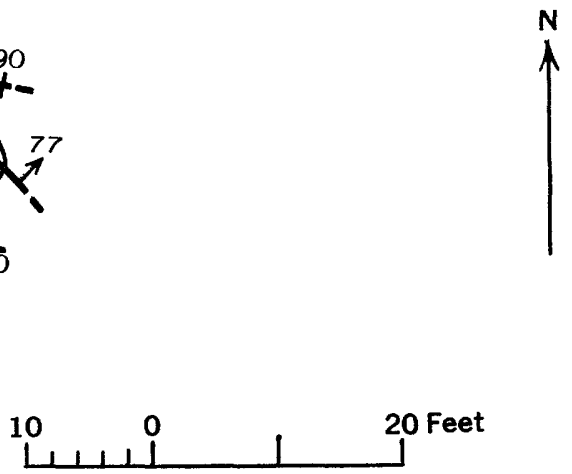

Figure 62.-Map of the southern adit on the Donna Lee claims.

The southern adit (fig. 62) follows a strong limonite-filled fracture that splits a few feet from the portal and comes together again about 50 feet farther into the adit. Ore-bearing rock is generally adjacent to the limonite-filled fractures; the most radioactive rock is between the splits. The limonite filling and host rock immediately adjacent to the fractures are much less radioactive than the rock 2 inches to a foot away. Locally individual strata 1 to 3 inches thick are strongly radioactive for a strike length of as much as 10 feet. Minor joints 
transverse to the trend of the adit are also locally radioactive. The radioactivity along individual strata and minor fractures, however, is much less continuous than the general zone that parallels the fractures that trend N. $10^{\circ} \mathrm{E}$.

Pyrite was the only primary mineral identified, but chalcopyrite is probably present inasmuch as there is an abundance of secondary copper minerals. Metatorbernite is abundant along joints and is disseminated in clay-rich strata in near-surface parts of the deposit. Limonite, gypsum, and malachite also coat joints. Efflorescent chalcanthite is abundant on the mine walls near the portal of the northern adit.

\section{WORKMAN CREER AREA}

The Workman Creek area (pl. 47) includes approximately 6 square miles around the more than a dozen uranium deposits along the Workman Creek valley. The area is in the southwestern part of the McFadden Peak 15-minute quadrangle, about 46 miles north of Globe on the Globe-Young road.

The rocks exposed in the area include basalt, diabase, and sedimentary rocks from the Pioneer formation to the Troy quartzite. Basalt nearly 100 feet thick between the Mescal and the Troy corresponds to basalt found elsewhere at the top of the Apache group. A diabase sill believed to be nearly 1,000 feet thick underlies all the sedimentary rocks mapped in the area. East of the Globe-Young road the diabase intruded the upper member of the Dripping Spring, and west of the road it intruded the Pioneer even though the upper side of the sill is everywhere at an elevation of about 6,000 feet. The horizon of intrusion of the diabase changed along a major north-trending structure that represents either drag along a fault or a monoclinal fold breached by erosion.

Contact metamorphism adjacent to the diabase has resulted in two distinct types of metamorphic rock in the area. The upper member of the Dripping Spring is commonly converted to hornfels. The argillaceous basal beds of the Mescal in the large steeply dipping. xenolith (?) in the western part of the area are locally converted to magnetite- and serpentine-rich rock which has been explored by several shafts and adits, presumably for precious metals.

The uranium deposits are all in the upper member of the Dripping Spring near the contact with diabase. The better deposits are in hornfels. Ore bodies trend in a north-northeasterly or, less commonly, in a west-northwesterly direction. Most of the mining was started along a limonite-filled fracture at the surface, but experience has shown that these fractures are rarely traceable for more than a few tens of feet beneath the surface. In some of the ore bodies, the ore has the same trend as transition dikelets and zones of breccia. 
cemented by transition-dike material. The wall rock adjacent to transition dikes commonly contains ore.

The ore bodies are about 110 to 140 feet above the base of the upper member of the Dripping Spring quartzite. The exact stratigraphic positions cannot be measured in the vicinity of the mines because the base of the upper member is not present above the diabase. Approximate positions were determined by computation based on data from a measured section ( 360 feet thick) of the upper member exposed on the east flank of the monoclinal feature in the southwestern part of the map area. Here the diabase was apparently intruded between the upper and lower members.

\section{HOPE DEPOSTT}

The Hope deposit is on 1 of 16 claims in the NE1/4 sec. 30, T. $6 \mathrm{~N}$, R. 14 E., on the north side of the Workman Creek valley (pl.47). The owner is Arizona Continental Uranium, Inc. Access to the property is by a short side road that runs northward from the road along Workman Creek. Development of the claims in June 1955 was by a 360-foot adit in which a small part of the back had been stoped at about 200 and 290 feet from the portal.

The Dripping Spring quartzite in the vicinity of the adit dips $1^{\circ}-2^{\circ}$ NE. and is converted to hornfels above the diabase sill. The contact with the sill is gently discordant at the adit, but a few feet northwest it cuts irregularly down across nearly 50 feet of Dripping Spring strata (pl. 47). A local irregularity in the diabase contact is exposed inside the portal of the adit (fig. 63).

Host rock for the deposit is hornfels in the upper member of the Dripping Spring quartzite. The hornfels ranges from dark and medium gray to grayish pink. The adit follows an irregularly shaped and vaguely defined zone of transition dikes and breccia cemented by transition-dike material. Other sill-like and irregularly shaped bodies of transition-dike material are common in the adit but have no predominant trend.

The ore deposit is immediately above the diabase sill and 130 feet stratigraphically above the base of the upper member. Most of the ore is in the hornfels adjacent to the zone of transition-dike rocks. The zone is nearly vertical for about 200 feet into the adit. At 200 feet, however, the zone dips at increasingly lower angles toward the west. At about 300 feet the zone splits; the upper part continues for a short distance as a sill and the lower part plunges toward the north (fig. 63). Beyond 325 feet neither zone is exposed in the adit. Presumably, ore follows the lower zone below the adit level as far down as the diabase contact. The sill-like zone, however, has been explored by short percussion-drill holes and no ore-grade material was intersected. 


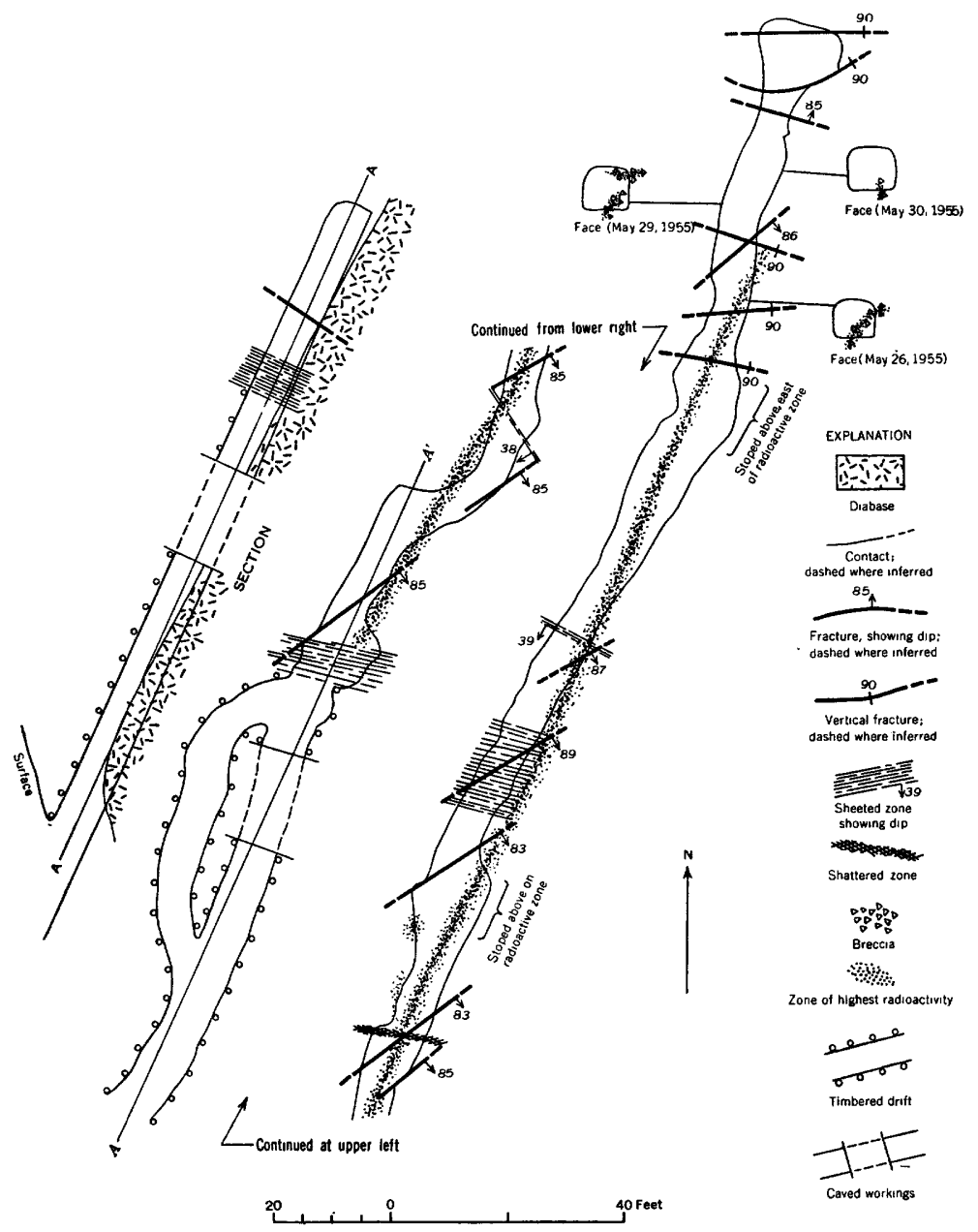

Frgure 63.-Map and sections of the Hope adit 1 .

Uraninite is the primary ore mineral in the mine and occurs for the most part in the dark hornfels adjacent to transition-dike rocks. More rarely, narrow veinlets of uraninite cut the transition dikes. The uraninite is closely associated with material altered to a greenish clay or chlorite.

Other minerals identified in the deposit are pyrrhotite, chalcopyrite, marcasite, pyrite, galena, and rare sphalerite. Their occurrence has been described under the heading Deposits in Hornfels. Uranophane and uraniferous hyalite are associated with limonite, gypsum, and minor amounts of secondary copper minerals in weathered parts of the deposit. 


\section{LTTTYE JOE DEPOSITS}

The Little Joe deposits are in sec. 19, T. 6 N., R. 14 E., on the north side of Workman Creek (pl. 47). Adit 1 is on 1 of 11 Little Joe claims located by Maurice Sharp and others of Globe, Ariz. Adit 1 trends about S. $80^{\circ}$ E. for 50 feet; other deposits on the Little Joe property are developed by 3 short adits and 2 bulldozed benches.

Adit 1 (fig. 64) is in weathered hornfels in the upper member of the Dripping Spring quartzite, about 4 feet above the diabase sill and about 140 feet stratigraphically above the base of the upper member.
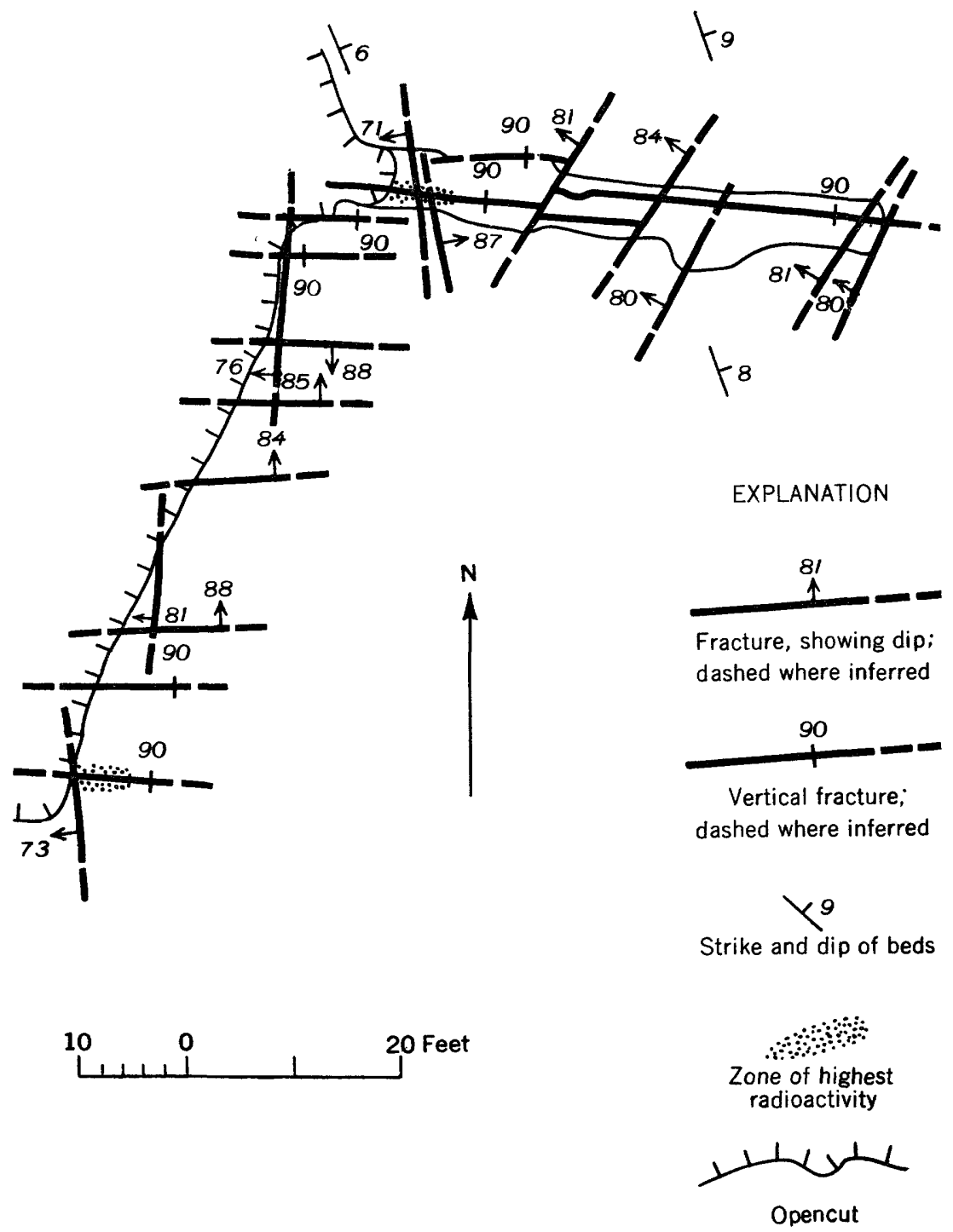

FradRi 64.-Map of the Little Joe adit 1. 
The host rocks $\operatorname{dip} 6^{\circ}-9^{\circ} \mathrm{E}$., but only 300 feet to the west the dip is nearly $20^{\circ} \mathrm{E}$. The steeper dips are along the east flank of the monoclinal feature.

Mining was started on a strong limonite-filled fracture that trends N. $82^{\circ} \mathrm{W}$. at the portal. About 15 feet into the adit this fracture terminates against a joint that trends $\mathrm{N} .34^{\circ} \mathrm{E}$. Beyond this point the adit was driven along other fractures that trend N. $80^{\circ} \mathrm{W}$. Similar fractures are exposed on a 65-foot bench south of the portal. Limonite in several of the fractures on the bench contains abundant mica identified by X-ray methods as phlogopite (Richard P. Marquiss, analyst).

Two bedding-plane faults of unknown displacement were noted in the adit. One starts 2 feet above the floor of the portal and becomes indistinct at about 20 feet from the portal. The other starts in the ceiling at 25 feet and enters the face at floor level. A narrow transition dike adjacent to the fracture at the portal is traceable for a few feet into the adit. Similar fractures along the bench appear to follow recrystallized hornfels zones or transition dikes with extremely irregular borders.

Sparce uranophane was noted at the Little Joe adit 1, but no primary uranium minerals were identified. Uraninite occurs in coarse-grained recrystallized hornfels from other deposits on the Little Joe claims. Primary sulfide minerals are not abundant.

Rock of near ore grade was reported by local miners to extend about 40 feet in to the adit, but in June 1955 strong radioactivity was recorded only near the portal. Radioactivity of a strong fracture about 60 feet southwest of the adit is as much as $1.6 \mathrm{mr}$ per $\mathrm{hr}$ where exposed on the bench. Radioactivity of most of the rock along the bench and in the adit is less than $0.4 \mathrm{mr}$ per $\mathrm{hr}$, but small areas near the floor and ceiling in the first 10 feet of the adit range from 0.5 to $1.0 \mathrm{mr}$ per $\mathrm{hr}$.

\section{LOST DOG DEPOSIT}

The Lost Dog deposit is in sec. 30, T. 6 N., R. 14 E., on the south side of Workman Creek (pl. 47). The deposit is on the Lost Dog claim, located by Pat Morgan and others and developed under lease by C. W. Via of Santa Fe, N. Mex. The property is developed by a wide bulldozed bench, an opencut, and two short adits.

The deposit is in nearly flat-lying dark-gray strata of the upper member of the Dripping Spring quartzite about 50 to 75 feet above the diabase sill. The contact between Dripping Spring and diabase is deeply covered with surficial rubble. The deposit is about 130 feet stratigraphically above the base of the upper member in rocks that are not metamorphosed but are cut by numerous fractures. The strongest set of fractures trends about N. $20^{\circ}$ E.; other fractures trend in a north-northwesterly direction. 
The main ore body is about 500 feet long in a N. $20^{\circ}$ E. direction. Rocks on both sides of a strong limonite-filled fracture are uraniferous over a width of about 5 feet. Locally, individual strata are ore bearing for greater distances laterally. At the north end the ore body is exposed on a bench and at the south end it is developed by an opencut about 15 feet deep. Between these workings the ore body is undeveloped so that it is impossible to tell whether it follows a single continuous fracture or two en echelon fractures. Other fractures parallel to the main ore body contained only small amounts of ore.

Metatorbernite and uraniferous hyalite are the only uraniumbearing minerals identified. The metatorbernite coats fractures and bedding planes and impregnates some thin strata. Limonite, gypsum, and a small amount of malachite are associated with the ore minerals.

\section{LUCKY STOP DEPOSIT}

The Lucky Stop deposit is in sec. 30, T. 6 N., R. 14 E., on the south side of Workman Creek (pl. 47). The property consists of 17 claims located and developed by J. O. Brunson and others. In June 1955 development consisted of an 85-foot adit, several prospect cuts, and a large bulldozed area.

Strata of the upper member of the Dripping Spring dip $1^{\circ}-4^{\circ} \mathrm{SE}$. near the adit. To the west the dip increases as the major structure is approached. The adit is about 50 feet above the diabase sill and about 120 feet stratigraphically above the base of the upper member. Fractures and joints near the adit trend N. $70^{\circ}-80^{\circ} \mathrm{W}$. and N. $15^{\circ}-$ $45^{\circ}$ E. (fig. 65 ) ; for the most part they are discontinuous. Most of the fractures contain as much as one-quarter of an inch of limonite.

The host rock for the deposit exposed in the adit is fine-grained siltstone commonly bleached from medium gray to pale gray or tan. Metamorphism to hornfels has been mild and discontinuous; much of the rock shows no metamorphic effects. The richest primary ore, however, was found in and near recrystallized hornfels.

The adit was driven $\mathrm{S} .10^{\circ} \mathrm{W}$. along a radioactive zone that had been traced on the surface. No continuous fracture was followed during mining, but certain strata seems to be more shattered along the zone than elsewhere. The ore zone is about 1 to 4 feet wide. Generally only a few strata contain ore, and locally these range in position from the ceiling to the floor of the nearly horizontal adit. Most of the richest rock was near the floor of the adit, and some ore was mined from shallow underhand stopes.

Uraninite is the primary ore mineral, and metatorbernite and uranophane are the secondary ore minerals. The uraninite occurs in small irregularly shaped blebs and veinlets. Metatorbernite is common at the surface in unmetamorphosed host rock, whereas uranophane is more closely associated with uraninite in hornfels. The host rock 


\section{EXPLANATION}

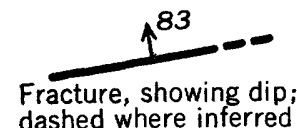

dashed where inferred

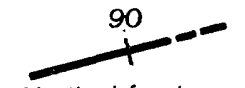

Vertical fracture; dashed where inferred
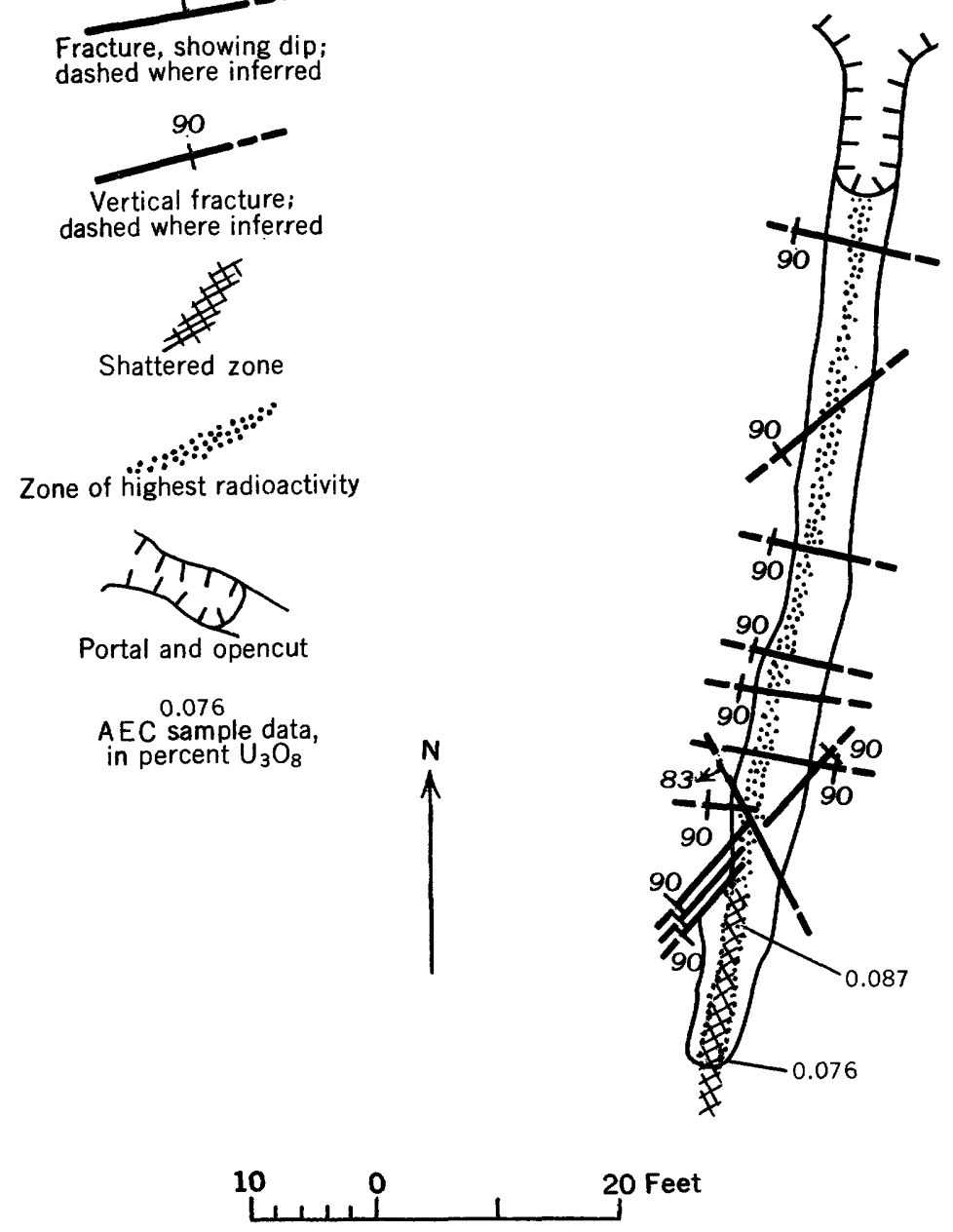

Figury 65.-Map of the Lucky Stop adit 1.

contains abundant pyrite and lesser amounts of pyrrhotite and chalcopyrite. Calcite locally fills cavities. Limonite stains all the nearsurface fractures, and gypsum is common in the fractures.

\section{SUCKERITE DEPOSTT}

The Suckerite prospect is in sec. 24, T. 6 N., R. 13 E. (unsurveyed) about 1,500 feet west of Aztec Lodge, in the Workman Creek area (pl. 47). The prospect is on 1 of a group of 16 Suckerite claims controlled in June 1955 by the Standard Ores and Alloys Co. The prospect has been explored by a bulldozed opencut about 100 feet long and by several diamond-drill holes. 
The deposit is on the west side of an elongate tilted block that is evidently a xenolith consisting of parts of the upper member of the Dripping Spring quartzite and basal Mescal limestone (pl. 47). Dips in this block range from about $15^{\circ}$ to about $55^{\circ} \mathrm{E}$.; at the deposit the dip is $45^{\circ} \mathrm{E}$. The deposit is about 140 feet stratigraphically above the base of the Upper member of the Dripping Spring.

The host rock is deeply weathered and broken by limonite-filled joints and fractures. The freshest rock is bleached, and the most strongly weathered rock is friable and iron stained. Apparently none of the host rock is metamorphosed to hornfels. The most abundant fractures in the host rock are nearly vertical and strike N. $70^{\circ} \mathrm{W}$. In general all other joints are poorly developed except for a few strong north-northeast-trending joints.

Radioactivity at the Suckerite prospect is strongest in the rocks in thin stratigraphic intervals; one is just above the diabase and the other is about 15 feet higher. The lateral extent of the radioactive strata is not known because of rubble and talus cover. Diamonddrill-core information was insufficient to determine the extent of the radioactivity downdip.

No primary uranium minerals were identified at the Suckerite deposit, but metatorbernite and uraniferous hyalite are associated with limonite and gypsum in the near-surface rocks. Maximum radioactivity measured with a portable scintillation meter is about $3.0 \mathrm{mr}$ per $\mathrm{hr}$; average radioactivity of rocks in the favorable intervals is less than $1.5 \mathrm{mr}$ per hr.

\section{WORKMAN DEPOSIT}

The Workman deposit is in sec. 19, T. 6 N., R. 14 E., on the north side of Workman Creek (pl. 47). Workman adit 1 is on a group of 16 Workman claims owned by Arizona Continental Uranium, Inc. The property was developed by two adits and several bulldozed benches by May 1955. Adit no. 1 was 105 feet long in a N. $19^{\circ} \mathrm{E}$. direction; the second adit was shorter and was largely in diabase below the top of the sill.

Adit 1 was driven in hornfels in the Dripping Spring quartzite just above the diabase sill and about 140 feet stratigraphically above the base of the upper member. Dips measured in the host strata range greatly; the average is about $5^{\circ} \mathrm{NE}$.

The contact between the diabase and the Dripping Spring is for the most part concordant throughout the area, but at the portal of the adit the contact is locally discordant (fig. 66). The contact continues to be discordant for several feet northwest of the portal.

Nearly vertical fractures that strike N. $60^{\circ}-80^{\circ} \mathrm{W}$. are common in the host rock and contain as much as half an inch of limonite near the surface. Fractures that trend north-northeast are less common. 
The ore body is, for the first 60 feet, in dark-colored hornfels in and adjacent to an irregularly shaped and ill-defined zone of transition dikelets and breccia. Beyond 60 feet the radioactivity decreases, but abnormally high radioactivity can be traced to the end of the drift.

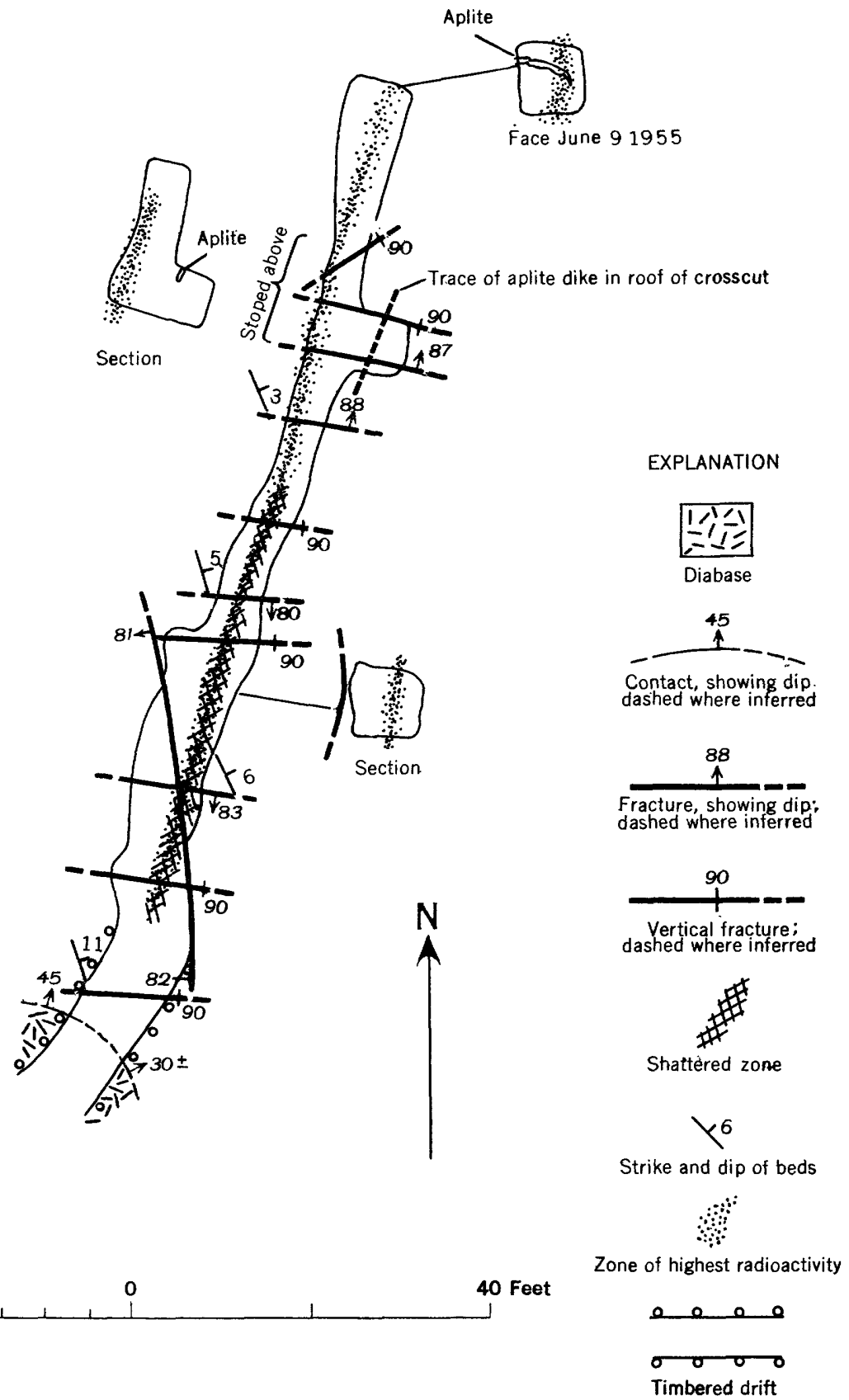

Figurn 66.-Map and sections of the Workman adit 1. 
The radioactive zone is more continuous than any other mappable feature in the adit. The ore body was 2 to 3 feet wide for the first 60 feet. In the stope that is 60 feet from the portal the top of the oregrade material plunges steeply northward.

Uraninite and coffinite are the primary minerals in this adit. Coffinite has been identified only by X-ray methods. The uraninite forms small blebs and irregularly shaped veinlets in the hornfels adjacent to the zone of transition dikelets; it is associated with pyrrhotite and less abundant chalcopyrite and molybdenite. The sulfide minerals are disseminated throughout the host rock, but are especially abundant in and near transition dikes. At the surface the secondary uranium minerals uranophane and metatorbernite are associated with limonite and gypsum in fractures.

\section{MESCAI MOUNTAINS AREA}

\section{LUCKY BOY DEPOSIT}

The Lucky Boy deposit is in sec. 31 and 32, T. 2 S., R. 15 E., in the Mescal Mountains (fig. 51). It is west of the Pioneer Pass road and about three-quarters of a mile southwest of Pioneer Stage Station in the Ray 15-minute quadrangle. The Lucky Boy property consists of a group of 50 claims owned by G. A. Stacey and others of Clifton, Ariz., and leased by the Phelps-Dodge Corp. Exploration included bulldozing shallow cuts and wagon drilling 13 vertical holes.

Host rocks for the deposit are strongly bleached and iron-stained strata of the upper member of the Dripping Spring quartzite. In the vicinity of the deposit the average strike is about $\mathrm{N} .50^{\circ} \mathrm{W}$. and the average dip is about $25^{\circ} \mathrm{SW}$. (pl.48). The Dripping Spring is overlain unconformably by the Mescal limestone, about 170 feet stratigraphically above the deposit, and is intruded by a discordant body of diabase about 50 feet below the deposit (section $A-A^{\prime}, \mathrm{pl} .48$ ). The rocks in the area are tilted south by northwest-trending block faults and are shattered by strong joints. The dominant joints trend northeast and commonly dip steeply northwest.

The Lucky Boy deposit is predominantly stratigraphically controlled. Unlike the deposits in the Sierra Ancha, the Lucky Boy deposit exhibits little elongation along limonite-filled fractures. Isorad lines representing values of radioactivity from 0.05 to $2.0 \mathrm{mr}$ per $\mathrm{hr}$ indicate that the radioactive areas are parallel to the bedding ( $\mathrm{pl}$. 48). Local irregularities in the isorads are elongate in a northeasterly direction, suggesting that joints may in part control the distribution of secondary minerals.

Metatorbernite associated with limonite is abundant in the most radioactive parts of the deposit; no primary uranium minerals were identified. The uranium near the surface of the deposit is out of equilibrium; two samples collected by personnel of the U. S. Atomic 
Energy Commission contained 0.034 and 0.038 percent $\mathrm{U}_{3} \mathrm{O}_{8}$, but radioactivity of the samples was equivalent to 0.10 and 0.13 percent $\mathrm{U}_{3} \mathrm{O}_{8}$, respectively.

\section{SKY DEPOSIT}

The Sky deposit is in sec. 2 (?), T. 3 S., R. 15 E., (unsurveyed) in the Mescal Mountains, about 14 miles south of Globe (fig. 51). The property is in a block of about 20 claims owned by G. K. Angius and others of Miami, Ariz. The property has been developed by several prospect pits and diamond-drill holes by the lessee, O. C. Swain of Whittier, Calif.

The Dripping Spring quartzite in the vicinity of the Sky claims is exposed along the south wall of a west-trending canyon. The rocks strike west and dip $20^{\circ}-30^{\circ} \mathrm{S}$. A discordant body of diabase south of the deposit cuts the upper part of the Dripping Spring.

Host rocks for the Sky deposit are 2 to 4 feet of shale and platy siltstone strata at the base of the upper member of the Dripping Spring. These rocks may be the basal strata of rocks that fill a broad, shallow, paleochannel cut into the well-cemented quartzite strata of the lower member. Dark-gray platy and flaggy siltstone strata typical of the middle part of the upper member are abnormally radioactive in several places in this area; they are stratigraphically higher than the deposits.

Radioactivity is strong and continuous along an outcrop length of less than 200 feet, but locally high radioactivity at the base of the upper member was noted over more than 400 feet of outcrop. Metatorbernite and malachite are associated with limonite and gypsum along fractures and bedding planes. No primary minerals other than pyrite were identified.

\section{ROOSEVELT QUADRANGLE AREA}

\section{BLEVINS CANYON DEPOSIT}

The Blevins Canyon deposit is on the north wall of a canyon about 16 miles north-northeast of Roosevelt Dam (fig. 51). The property consists of 16 claims owned by the Bridger-Jack Mining Co. Development consists of an adit and several prospect pits. In June 1955, the U.S. Bureau of Mines supervised the drilling of three exploratory diamond-drill holes near the deposit on behalf of the U. S. Atomic Energy Commission.

The Dripping Spring quartzite is nearly flat lying in the Blevins Canyon area. The canyon rim is in dark-gray siltstone strata of the upper member, about 75 feet above the contact between the upper and lower members of the Dripping Spring. A few hundred yards to the north a large diabase body has a discordant contact with the upper member. A copper-bearing quartz vein strikes $\mathrm{N}$. $75^{\circ} \mathrm{W}$. about 200 feet north of the canyon rim above the deposit. Abundant joints strike N. $25^{\circ}-50^{\circ} \mathrm{E}$. and N. $40^{\circ}-70^{\circ} \mathrm{W}$. 
The deposit is in basal strata of the upper member at the bottom of a paleochannel cut in the top of the lower member. The channel, as exposed on the north wall of the southeast-trending canyon, is about 700 feet wide and 50 feet deep. Exposures are insufficient to determine the length or trend of the channel. The rocks in the lower part of the channel are blocky to massive fine-grained feldspathic quartzite and thin conglomerate. The richest ore at outcrop is in shaly lenses in the quartzite.

Uranium minerals are disseminated in the shaly lenses, along bedding planes, and more rarely on the surfaces of small discontinuous fractures. The feldspathic quartzite beds are much less radioactive, and visible uranium minerals in them are rare. These rocks are abnormally radioactive for more than 200 feet horizontally and less than 15 feet vertically, but only at a very few places does the radioactivity exceed $1.0 \mathrm{mr}$ per $\mathrm{hr}$. The diamond-drill holes intersected thin radioactive zones in the strata in the favorable stratigraphic interval about 200 feet back from the outcrop.

Metatorbernite is the principal uranium mineral in the deposit; no primary uranium minerals are identified. Malachite very commonly stains the surface and fracture planes, but concentrations of malachite and metatorbernite do not seem to be related to each other.

\section{FAIRVIEW DEPOSIT}

The Fairview deposit is on a south-trending ridge about 15 miles north-northeast of Roosevelt Dam in the Roosevelt 30-minute quadrangle (fig. 51). The deposit is on a group of 16 claims owned by E. C. Conway and others of Tonto Basin, Ariz. It has been developed by an open cut, a small pit, and a bulldozed area. The open cut trends N. $60^{\circ}$ E. for 20 feet and is 10 feet deep at the face.

Dripping Spring quartzite, Mescal limestone, and Troy quartzite are exposed near the Fairview deposit. A diabase sill(?), now mostly removed by erosion, intruded the upper member of the Dripping Spring above the deposit. To the east the diabase cuts down abruptly across Dripping Spring strata.

The host rock is weathered and bleached flaggy siltstone about 65 feet above the base of the upper member. The strata strike about N. $65^{\circ} \mathrm{W}$. and $\operatorname{dip} 5^{\circ} \mathrm{SW}$. Strong vertical joints that strike N. $60^{\circ}-$ $65^{\circ} \mathrm{E}$. seemingly have no relation to the radioactivity.

The radioactive area has no strong trend or elongation. Individual strata are radioactive only locally. Inasmuch as some of the radioactive rocks are very strongly weathered and friable, whereas others are well indurated and limonite stained, the distribution of radioactive minerals may be in part caused by differential weathering and movement of primary uranium and daughter products by meteoric waters. 
Metatorbernite and less abundant yellow uranium minerals that were not identified coat fracture surfaces and impregnate the more friable rock. The radioactivity is locally as much as $5.0 \mathrm{mr}$ per $\mathrm{hr}$ near concentrations of uranium minerals but is less than $0.5 \mathrm{mr}$ per hr over most of the deposit.

\section{GREAT GAIN DEPOSIT}

The Great Gain deposit is on the south wall of a canyon about 18 miles north-northeast of Roosevelt Dam in the Roosevelt 30-minute quadrangle (fig. 51). The group of five Great Gain claims is owned by William Minarek of Globe, Ariz., and leased to the Desert Queen Uranium Co. of Whittier, Calif. Development of the property in June 1955 was by several prospect pits and small benches along the canyon wall.

The canyon is cut in flat-lying strata of the Dripping Spring quartzite. The rim of the canyon is in dark-gray platy and flaggy siltstone of the upper member, about 50 feet above the ore horizon. The floor of the canyon is in medium-grained quartzite and sandstone of the lower member. Steeply dipping fractures that strike N. $25^{\circ}-30^{\circ} \mathrm{E}$. and N. $50^{\circ}-60^{\circ} \mathrm{W}$. are common.

The uranium deposit is near the base of the upper member. In general, the deposit is less than 2 feet thick although locally rocks in a stratigraphic interval of as much as 5 feet are abnormally radioactive. Anomalously high radioactivity in the favorable strata is traceable for more than 750 feet along the irregular outcrop, but the true strike length of the deposit is probably not much more than 300 feet.

Metatorbernite is common on joints and bedding planes; a fluorescent mineral that may be uranocircite is much less common. Limonite is locally abundant. Radioactivity in the favorable strata is between 0.25 and $1.0 \mathrm{mr}$ per $\mathrm{hr}$.

\section{OTHER DEPOSITS}

BLACK BRUSH DEPOSIT

The Black Brush deposit is in the SE1/4 sec. 4, T. 6 N., R. 14 E., on the west side of the Cherry Creek canyon (fig. 51). An ungraded road suitable only for 4-wheel-drive vehicles extends about 10 miles to the deposit from the Globe-Young road, about 55 miles north of Globe. The property consists of a group of 10 claims, 7 of which were located by T. E. Ellison and 3 by C. A. Saylor. Development consists mainly of a 70-foot drift and a 35-foot crosscut (fig. 67) driven by the Western Mining and Development Co. of Phoenix, Ariz.

The deposit is on the south slope of a ridge between two northeasttrending canyons that connect with the Cherry Creek canyon. It 


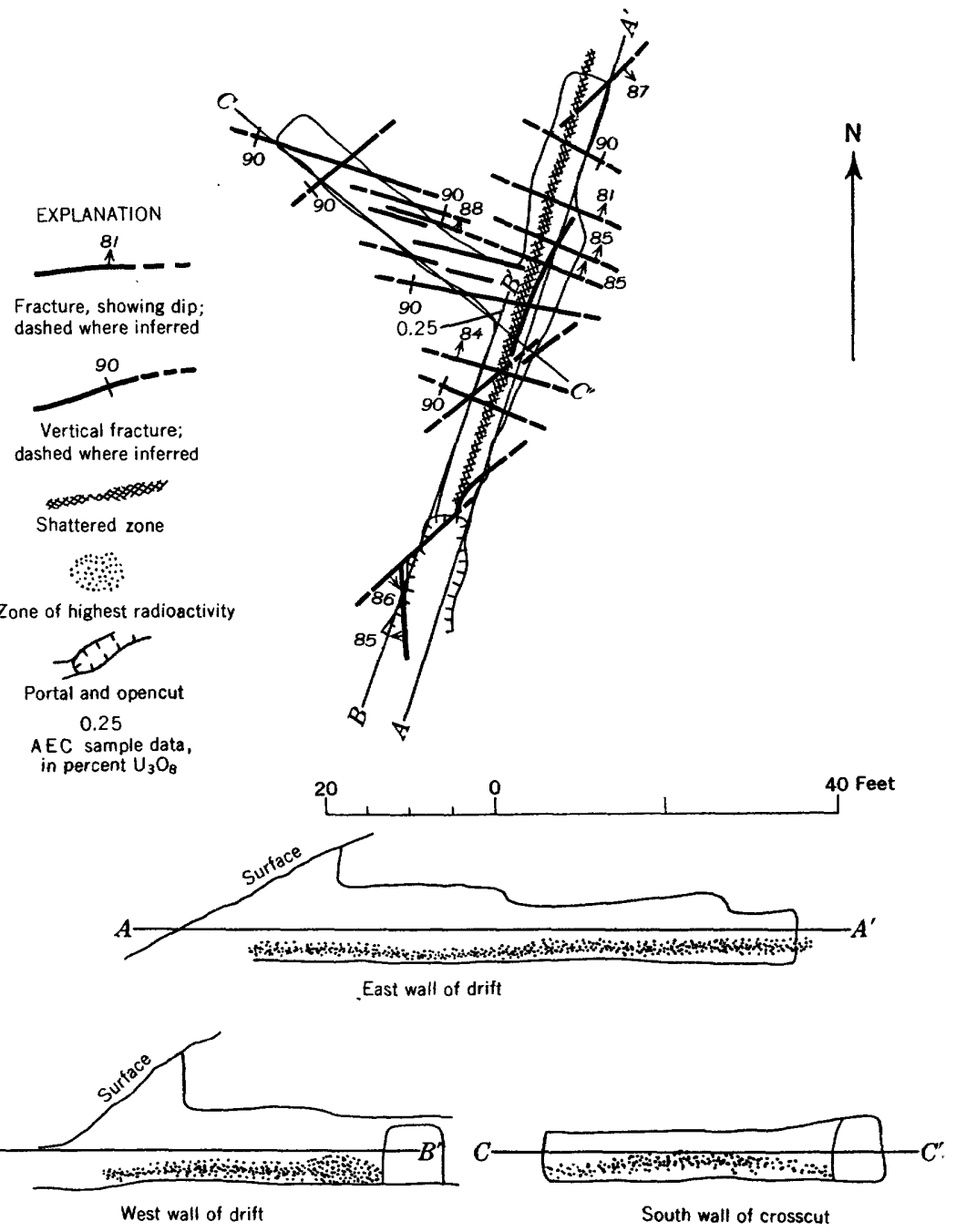

Sections, showing zone of highest radioactivity

Figure 67.-Map and sections of the Black Brush adit.

is about 80 feet above a diabase sill that cuts basal strata of the upper member of the Dripping Spring quartzite. Strata below the deposit form cliffs, and those above the deposit form steep slopes. The deposit is about 120 to 130 feet stratigraphically above the base of the upper member, and thus is similar in position to the Snakebit and Rainbow deposits.

The Dripping Spring is nearly flat lying in the vicinity of the Black Brush adit. Just above the diabase the Dripping Spring is locally. converted to hornfels, but no evidence of contact meta- 
morphism was noted at the ore horizon. The strongest joints near the deposit trend N. $70^{\circ}-80^{\circ}$ W. and N. $20^{\circ}$ E. They are commonly filled with limonite.

Mining was started along a fracture trending N. $20^{\circ}$ E. that was strongly radioactive at the surface. About 40 feet from the portal the fracture diverges toward the east from the zone of highest radioactivity. Beyond this point the zone of highest radioactivity follows no particular fracture, but it is reportedly much easier to drill than the adjacent rock. It is shown on figure 65 as shattered rock.

Nearly all the primary uranium minerals are in rocks in a 1-foot stratigraphic interval. The minerals are in nearly black siltstone above a bed of medium- to coarse-grained pinkish quartzite that is 1 to $11 / 2$ feet thick. Scattered light-colored pebbles at the base of the quartzite bed are commonly blade shaped and appear to be sericitized.

Uraninite occurs as irregularly shaped blebs that are chiefly in the black siltstone but have also been found in the upper part of the underlying bed of quartzite. Pyrrhotite, chalcopyrite, and pyrite or marcasite are localized in the quartzite bed and are much less abundant in the overlying siltstone. Metatorbernite is associated with limonite on fracture planes in near-surface parts of the deposit.

Radioactivity in the favorable strata is strongest along the zone that trends N. $20^{\circ}$ E. Locally it exceeds $5.0 \mathrm{mr}$ per $\mathrm{hr}$ on the walls of the adit. It fades out abruptly away from the adit, however, and is less than $0.75 \mathrm{mr}$ per $\mathrm{hr}$ at the end of the crosscut.

\section{FIrst chance deposit}

The First Chance deposit is in sec. 1, T. 5 N., R. 13 E., about onehalf mile north of the Parker Creek Experiment Station (fig. 51). It is accessible by an ungraded dirt road that joins the Globe-Young road less than one-half mile northwest of the experiment station. The property includes four First Chance claims located by Mr. Van Baker and others. Exploration of the deposit has been by the Arizona Continental Uranium Co. Development work consists of several bulldozed benches below the location pit (fig. 68).

The deposit is on a steep south-facing slope overlooking the experiment station. It is in nearly flat-lying siltstone and very fine grained quartzite of the upper member of the Dripping Spring quartzite. The southern extension of the major monoclinal structural feature described in the Workman Creek area is about three-quarters of a mile west of the deposit. Below the deposit a thick locally discordant diabase sill cuts the lower member of the Dripping Spring.

A strong limonite-filled fracture that trends about N. $25^{\circ} \mathrm{E}$. is radioactive throughout rocks in a stratigraphic interval of more than 30 feet beginning about 110 feet above the base of the upper member. Although the fracture locally contains as much as 2 inches 
of gouge and breccia, no vertical displacement was observed. The rocks at the deposit are strongly weathered and bleached, but nearby they are flaggy and platy dark-gray siltstone typical of the middle part of the upper member.

The strongest radioactivity is adjacent to the fracture. Ore-grade material probably has a maximum width of no more than 3 feet.

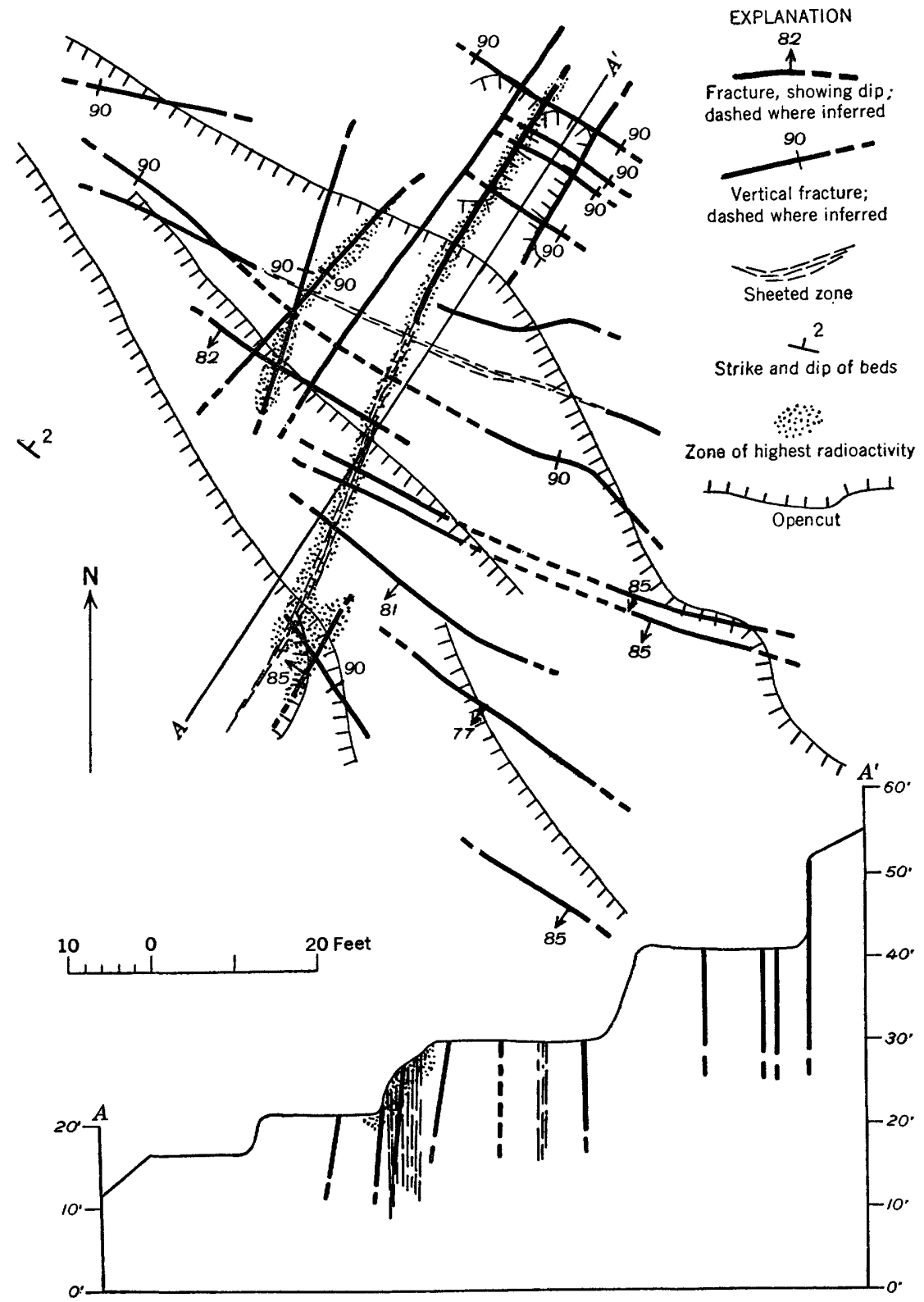

Figdrn 68.-Geologic map and section of the First Chance deposit. 
Parallel fractures near the main fracture are locally radioactive, but transverse fractures contain only small amounts of secondary uranium minerals.

No primary uranium minerals were identified. Pyrite is abundant where not oxidized to limonite, and chalcopyrite is disseminated in the gouge-filled parts of the fracture and nearby joints. Metatorbernite is abundant on joint surfaces near the main fracture and is associated with limonite and gypsum. Chalcocite and covellite have locally replaced chalcopyrite; malachite and azurite sparingly coat joint surfaces.

Radioactivity adjacent to the main fracture in strata in the favorable stratigraphic interval ranges from 1.0 to $3.0 \mathrm{mr}$ per $\mathrm{hr}$. Comparable radioactivity was noted along nearby parallel fractures. Away from the deposit radioactivity abruptly drops below $0.1 \mathrm{mr}$ per hr.

\section{SHHPP NO. 2 DEPOSIT}

The Shepp No. 2 mine is in sec. 31 , T. 8 N., R. 15 E., and sec. 36 , T. 8 N., R. 14 E., about 17 miles by ungraded dirt road southeast of Young (fig. 51). The mine is on 1 of 5 Shepp claims located by O. H. Shepp and leased to the American Asbestos and Uranium Co. Development consists of 4 adits that total about 610 feet of workings. Two adits were driven into each wall at the bottom of the narrow cliff-flanked Wilson Creek canyon (fig. 69).

Nearly flat-lying Dripping Spring quartzite and Mescal limestone are exposed in the Shepp claims area. A diabase sill that was intruded just below the top of the lower Mescal is exposed about one-half mile north of the area. A little more than one-half mile south of the area a steeply discordant body of diabase cuts both Mescal and Dripping Spring strata.

The strongest joints and fractures in the area trend N. $70^{\circ}-80^{\circ} \mathrm{W}$. They are generally limonite filled near the surface but may contain calcite where unweathered. There has been minor movement along these fractures; displacement of nearly 2 feet has been noted. Zones of breccia and gouge along these fractures are as much as 10 feet wide (fig. 69). Joints that trend N. $10^{\circ}-15^{\circ} \mathrm{E}$. are also prominent in the area, but no displacement along them has been noted. They also contain limonite but are not as wide as those of the set that trends N. $70^{\circ}-80^{\circ} \mathrm{W}$.

The deposits are in dark-gray flaggy indurated siltstone about 45 to 70 feet above the base of the upper member of the Dripping Spring. The rocks are bleached and stained by iron oxides at the surface and adjacent to the shear zones exposed in the adits.

No distinct or continuous ore body has been found in the adits, but experience has shown that more ore-grade rock could be removed by following N. $10^{\circ}-15^{\circ}$ E. trends than by crosscutting. All the rock 
exposed in the adits is abnormally radioactive, but the rock richest in uranium in unweathered parts of the mine is very discontinuous and irregularly distributed. At places the most radioactive material is in a bed near the ceiling of an adit, and in other places it may be near

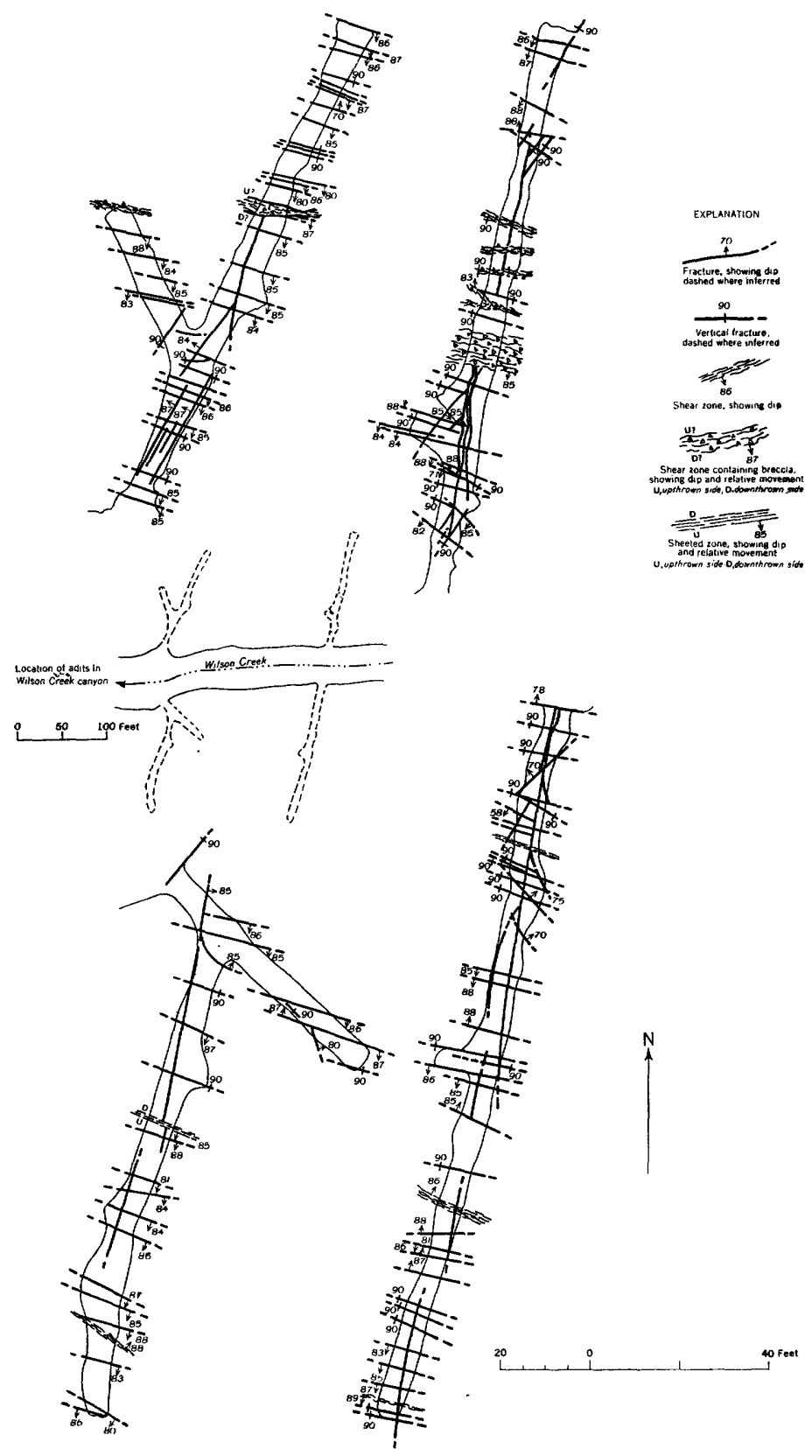

FradRe 69.-Map of the Shepp No. 2 mine. 
the floor. The fractures, where comparatively unweathered, are no more radioactive than the wall rock. No individual zone of high radioactivity is continuous for more than a few feet in any direction.

No primary uranium mineral has been identified at the Shepp No. 2 mine, but pyrite and chalcopyrite are present. Study of heavymineral separates, air-elutriation separates, and autoradiographs suggest that some of the uranium may be in a colloidal form, perhaps adsorbed on clay minerals. Tracks of alpha particles emitted from clay minerals were noted in some of the autoradiographs. Fine pyrite and less abundant chalcopyrite are disseminated in the host rock. Locally pyrite is associated with calcite in fractures.

Metatorbernite is abundant in fractures near the surface. It is commonly associated with limonite and less commonly with gypsum, malachite, and azurite.

Radioactivity in the deposit ranges from 0.1 to nearly $5.0 \mathrm{mr}$ per $\mathrm{hr}$. The lowest radioactivity is on weathered surfaces, in crosscuts, and in oxidized shear and breccia zones in the adits. The highest radioactivity is on metatorbernite-coated surfaces and in local uraniferous beds.

\section{SNAKEBIT DEPOSIT}

The Snakebit deposit is about 3 miles south of the Regal asbestos mine in the southern part of the Blue House Mountain 15-minute quadrangle (fig. 51). The property is accessible by dirt road west from U. S. Highway 60, south of the Salt River canyon. The deposit is on a group of nine Snakebit claims owned by C. S. Black and developed under lease by the Cable Development Co. Development consists of a benched area about 30 feet long and 15 feet wide from which an adit has been driven in a northwesterly direction.

The deposit is in nearly flat-lying strata part way down a steep canyon wall; beneath the deposit nearly vertical cliffs are several hundred feet high. The base of the upper member of the Dripping Spring quartzite is about 130 feet below the deposit.

A thick diabase sill intruded the lower member of the Dripping Spring below the deposit, but about a quarter of a mile to the west the upper contact of the diabase cuts across strata of the upper member.

Nearly vertical joints near the deposit strike N. $75^{\circ}-85^{\circ} \mathrm{W}$. and $\mathrm{N}$. $5^{\circ}-15^{\circ} \mathrm{E}$.; they are commonly filled with as much as one-quarter of an inch of limonite. In less weathered parts of the adit these joints are filled with pyrite and calcite. Crumpled mud cracks are common, and pyrite-filled stylolites are abundant in the dark-gray strata above the deposit.

The most radioactive rock in the workings is along a zone about 5 to 10 inches thick that roughly follows the stratification. It is at about waist height on the bench and in the portal of the adit. The 
rock in this zone is iron-stained very fine grained quartzite. About 2 feet below the radioactive zone a 4 -inch bed of medium- to coarsegrained quartzite contains abundant sulfide and secondary minerals. Both the radioactivity and sulfide minerals are concentrated near a prominent limonite-filled joint that trends $\mathrm{N} .10^{\circ} \mathrm{E}$. across the portal of the adit. The adit trends nearly at a right angle to this joint.

No primary uranium mineral was identified at the deposit. Sulfide minerals include abundant pyrite and chalcopyrite, galena, and sparse sphalerite. Metatorbernite is associated with abundant limonite in weathered parts of the deposit.

Radioactivity near the joint that trends N. $10^{\circ}$ E. ranges from about 0.2 to $1.0 \mathrm{mr}$ per hr, but it is much lower in the adit.

\section{IITERATURE CITED}

Allen, M. A., and Butler, G. M., 1921, Asbestos : Arizona Bureau Mines Bull. 113. Anderson, C. A., 1951, Older Precambrian structure in Arizona: Geol. Soc. America Bull., v. 62, no. 11, p. 1331-1346.

Bateman, A. M., 1923, An Arizona asbestos deposit: Econ. Geology, v. 18, no. 7, p. 663-683.

Butler, G. M., 1929, Geological occurrence of Arizona asbestos : Pan-Am. Geologist, v. 52, no. 1, p. 19-26.

Darton, N. H., 1925, A resume of Arizona geology: Arizona Bur. Mines Bull. 119.

- 1932, Some Algonkian strata of Arizona and adjoining regions: Wash. Acad. Sci. Jour., v. 22, no. 11.

Duel, Maurice, 1956, Colloidal method for concentration of Carbonaceous matter from rocks: Petroleum Geologists, Bull., Am. Assoc., v. 40, no. 5, p. 909-917.

Edwards, A. B., 1947, Textures of the ore minerals: Australasian Inst. of Min. and Metallurgy (Inc.).

Fenneman, N. M., 1931, Physiography of Western United States: New York, McGraw-Hill Book Co.

Gilbert, G. K., 1875, Geology of portions of New Mexico and Arizona, explored and surveyed in 1873: U. S. Geog. and Geol. Surveys West of the One Hundredth Meridian, v. 3, pt. 5.

Goddard, E. N. (chm.), and others, 1948, Rock-color chart: Washington, D. C., Natl. Research Council.

Gruner, J. W., 1954, Further experiments on the synthesis of uraninite-pt. 3, Annual Report for April 1, 1953 to March 31, 1954, Minn. Univ.: U. S. Atomic Energy Comm. RME-3094, Tech. Inf. Service, Oak Ridge, Tenn.

Kaiser, E. P., 1951, Uraniferous quartzite, Red Bluff prospect, Gila County, Arizona: U. S. Geol. Survey Circ. 137.

Lee, W. T., 1905, Underground waters of Salt River Valley, Arizona : U. S. Geol. Survey Water-Supply Paper 136.

McKee, E. D., and Weir, G. W. 1953, Terminology for stratification and crossstratification in sedimentary rocks: Geol. Soc. America Bull., v. 64, p. 381390.

Magleby, D. N., and Mead, W. E., 1955, Airborne reconnaissance project, Dripping Spring quartzite, Arizona: U. S. Atomic Energy Comm. RME-2023, Tech. Inf. Service, Oak Ridge. [Tenn.] 
Mead, W. E., and Wells, R. L., 1953, Preliminary reconnaissance of the Dripping Spring quartzite formation in Gila and Pinal Counties, Arizona: U. S. Atomic Energy Comm. RME-4037, Tech. Ind. Service, Oak Ridge. [Tenn.]

Peterson, N. P., Gilbert, C. M., and Quick, G. L., 1951, Geology and ore deposits of the Castle Dome area, Gila County, Arizona: U. S. Geol. Survey Bull. 971.

Ransome, F. L., 1903, Geology of the Globe Copper district, Arizona : U. S. Geol. Survey Prof. Paper 12.

1916, Some Paleozoic sections in Arizona and their correlation : U. S. Geol. Survey Prof. Paper 98-K, p. 133-166.

1919, The copper deposits of Ray and Miami, Arizona: U. S. Geol. Survey Prof. Paper 115.

1932, Ore deposits of the Southwest: Internat. Geol. Cong., 16th, Guidebook 14 .

Reagan, A. B., 1903, Geology of the Fort Apache Region in Arizona : Am. Geologist, v. 32, p. 265-308.

1932, Geological notes on the Fort Apache Region, Arizona : Kansas Acad. Sci. Trans., v. 35, p. 260-273.

Sampson, Edward, 1924, Arizona asbestos deposits : Econ. Geology, v. 19, no. 4, p. 386-388.

Shride, A. F., 1952, Localization of Arizona chrysotile asbestos deposits [abs.] : Geol. Soc. America Bull., v. 63, no. 12, pt. 2, p. 1344.

Short, M. N., and others, 1943, Geology and ore deposits of the Superior mining area : Arizona Bur. Mines Bull. 151.

Stanton, R. L., 1955, Lower Paleozoic mineralization near Bathurst, New South Wales : Econ. Geology, v. 50, no. 7, p. 681-714.

Stoyanow, A. A., 1930, Cambric formations of southeastern Arizona and their Trilobitic faunas [abs] : Pan Am. Geologist. v. 53, no. 4, p. 315.

Trischka, Carl, 1927, Asbestos and the Arizona industry : Eng. and Min. Jour., v. 124 , no. 9, p. 337-340.

Wells, R. L., and Rambosek, A. J., 1954, Uranium occurrences in Wilson Creek area, Gila County, Arizona : U. S. Atomic Energy Comm. RME-2005 (revised), Tech. Inf. Service, Oak Ridge. [Tenn.]

Wilson, E. D., 1922, Proterozoic Mazatzal quartzite of Central Arizona : Pan-Am. Geologist, v. 38, no. 4, p. 299-312.

1928, Asbestos deposits of Arizona; with an introduction on asbestos minerals by G. M. Butler : Arizona Bur. Mines Bull. 126.

Wright, R. J., 1950, Reconnaissance of certain uranium deposits in Arizona: U. S. Atomic Energy Comm. RMO-679 (open-file report), Tech. Inf. Service, Oak Ridge. [Tenn.] 



\section{INDEX}

\begin{tabular}{|c|c|}
\hline age & \\
\hline tinolite. & lkes, hornfels. . \\
\hline lbite, diabase. & ore control \\
\hline 430 & olomite. \\
\hline mphibole...... & $\ldots-461-463$ \\
\hline$\ldots$ & 420 \\
\hline - & $\ldots-\ldots 22-424$ \\
\hline ben............ & D..- $440-444$ \\
\hline e................ & $450-453$ \\
\hline roup, age & 438,439 \\
\hline _.. 420,421 & -425 \\
\hline patite..... & nfels. \\
\hline $434-435,451$ & \\
\hline 427,428 & 428 \\
\hline _... 430 & xploration \\
\hline 444 & \\
\hline 444 & 435,436 \\
\hline $420,421-422$ & - \\
\hline $\begin{array}{r}418 \\
426-427\end{array}$ & $\begin{array}{l}427,428,429 \\
-430,431,446\end{array}$ \\
\hline$\ldots-144$ & $\begin{array}{r}200,401,+40 \\
\ldots . .422,425\end{array}$ \\
\hline 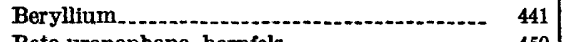 & $\ldots \ldots 77-479$ \\
\hline - & \\
\hline$\ldots 44$ & 446,4 \\
\hline $427,428,429$ & $441,443,444$ \\
\hline -...- & -- 435 \\
\hline -......- & - \\
\hline 473-474 & (n) \\
\hline 431,445 & Grap \\
\hline -....... & 418 \\
\hline (n..... & (n) \\
\hline$\ldots \quad 445$ & 450 \\
\hline .... 459-463 & $\ldots+\ldots$ \\
\hline$\ldots 437,450$ & \\
\hline 431 & 4 \\
\hline $\begin{array}{r}443,444,450 \\
-\quad 450\end{array}$ & $429-434$ \\
\hline (n) & $444-450$ \\
\hline $\begin{array}{r}441,446,448,449 \\
-141,443\end{array}$ & rnfels. \\
\hline 426 & \\
\hline iabase. & - \\
\hline 446 & (n) \\
\hline 442 & (n) \\
\hline ts. & $\ldots 431,441,442,449$ \\
\hline Climate. & - \\
\hline Cobalt & $-435,436,44$ \\
\hline 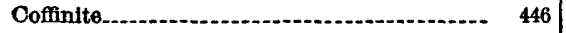 & \\
\hline - & Coolin . - \\
\hline hornfels. & 427 \\
\hline$\cdots--$ & - \\
\hline socks.- & Limonite, hornels \\
\hline $\begin{array}{l}\text { labase, age } \\
\text { aplitic factes }\end{array}$ & $\begin{array}{r}440,445 \\
437,440,443\end{array}$ \\
\hline 436,442 & (n) \\
\hline 4 & ... $466-467$ \\
\hline -....... & - \\
\hline _. $428-429$ & prings formation of Gastil_. \\
\hline 438 & t....... $472-473$ \\
\hline & \\
\hline
\end{tabular}


Magnesium

Red Bluff area, deposits..................... 454-459

Magnetite, diabase.

Red Bluff deposit_............................. 457

iron ore

Malachite, hornfels............................ 450 siltstone_.................................. 444

Marcasite, hornfels _.................. 441, 446, 448, 449 siltstone.................................. 441, 443

Mescal limestone, age........................ 420 description_................................ 426 radioactivity............................. 438

Mescal Mountains .............................. 416

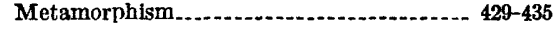

Metatorbernite_................... 444

Mining history .................... 439-440

Molybdenite, hornfels......................... 447,448 siltstone_.................................. 441

Molybdenum................................. 441

Monoclinal folds................................. 435

Nickel.

Nontronite, hornfels siltstone.

Oligoclase $\ldots \ldots \ldots \ldots \ldots \ldots$

Olivene, asbestos and serpentine............... 435 diabase....................................... 427, 428

Ore controls................ 440-441, 445-446, 450-453

Ore deposits, minerals.......................... 441 origin paragenetic sequence................. 441, 447, 448 shape-_.................................. 440 See also Diabase, Hornfels, Siltstone.

Orthoclase

Paleochannels..................................... 424

Paleozoic rocks _............................... 418

Pinal schist

Pioneer formation. ........................... 420

Plagioclase . . ............................ 427, 428, 429

Potassium, hornfels............................. 431 siltstone.............................. 431, 439

Precambrian rocks.

Primary uranium minerals, hornfels......... 441, 446 siltstone................................... 441, 442

Pseudochannels, definition................. 437-438 ore control.................................... 441

Pyrite, basalt..................................... 426 dikes and breccia.......................... $\quad 450$ hornfels................................. 441, 449 siltstone................................ 441, 443, 444

Pyroxene, diabase......................... 428, 429 hornfels. . . iron ore

Pyrrhotite, hornfels . ..................... 446, 447, 449 siltstone....................................... 441

Quartz, diabase................................. 428, 429 hornfels ................................ 430, 431, 446

Quartz veins................................ 437

Quaternary rocks............................ 418

Radioactivity . $438-439$

Rainbow deposit $455-456$

Rople marks.......... 425

Sandstone ..................................... 422-424

Scanlan conglomerate......................... 420

Sericite .................... 428

Serpentine, diabase_.......................... $\quad 428$

limestone

Shepp No. 2 deposit....................... 479

Shride, A. F., quoted

Shrinkage cracks............ 425

Sierra Ancha. ........................ 416

Siltstone, autoradiograph....................... 443

ore deposits............................... 441-444

radioactivity .......................... 438, 439, 443

Silver. . . . . .

Sky deposit. . . . . .

Snakebit deposit............................. 481-482

Sodium............................................ 431

Specularite.................................. 426

Sphalerite, hornfols _...................... 441, 447,449 siltstone................................. 441, 443, 444

Sphene, diabase .............................. 428, 429 hornfels.................................... 430, 431

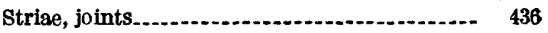
pseudochannels.............................. 438

Struetural features............................ 435-438

Stylolites.............................. 425, 443, 444

Suckerite deposit.

Sue deposit_................................... 459-461

Sulfur $\ldots \ldots \ldots \ldots$

Terminology . . . . .

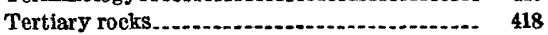

Titantum................ 431, 441

Topography................................... 416-417

Troy quartzite, age.......................... 418, 420

radioactivity ............................. 438

Unkar group................................... 420

Upper Dripping Springs formation of Gastil 425

Uraninite, hornfels........................... 446, 448 siltstone-................................. 441, 442

Uranium, correlation with other metals......- 441

Uranium minerals, primary ......... 441, 442, 445, 446 secondary ............................. 444, 450

Uranocircite....................................... 444

Uranophane, hornfels........................ $\quad 450$ siltstone...................................... 444

Vanadium_................................ 431, 441

Vegetation................................. 417

Wall-rock alteration

Wilson, E. D., quoted............... 434-435

Workman Creek area, deposits ............. 463-472

Workman deposit............................ 470-472

Yavapal schist............................. 418

Zircon 
